\title{
Assessing bird predation on New Zealand's lizard fauna using lizard-mimicking replicas
}

Brittany Jayne Florence-Bennett

\begin{abstract}
A thesis submitted to Victoria University of Wellington in partial fulfilment of the requirements for the degree of Master of Science in Ecology and Biodiversity
\end{abstract}

2020 





\section{Acknowledgments}

First and foremost, I would like to thank my supervisor, Nicky Nelson, without your guidance and encouragement this thesis would not be possible. You were always on hand to lend an ear, to reduce stress, and to offer opportunities - for that I am thankful.

I would also like to acknowledge the Nelson lab group (FixIt), I am extremely grateful to be part of such a supportive network. Thank you all for your endless draft edits, comments, and words of encouragement: Douglas Rand, Florence Kelly, Liam McAuliffe, Lin Lin Liu, Michelle Goh, Sarah Lamar, Sue Keall, and Sydney Dean. Special thanks to Chris Woolley, Ox Lennon, and Sarah Herbert for your constant support and willingness to answer endless questions throughout my entire postgraduate degree. Additional thanks to SBS staffer Neville Higgison for never tiring of printing lizard replicas, and to Lisa Woods for statistical advice and problem solving. I am grateful to Marleen Baling for permission to use the 3D shore skink scan as a base for my lizard replicas.

This research was funded by the Wellington City Council (WCC) Our Natural Resource Grant, and the Centre for Biodiversity and Restoration Ecology (CBRE) Student Grant. Funding to attend conferences and present my research was received from the Society for Research on Amphibians and Reptiles in New Zealand (SRARNZ) and the Victoria University of Wellington Faculty Strategic Research Grant. Thank you to Ngāti Toa and Taranaki Whānui ki Te Upoko o Te Ika for permission to conduct my research within sites around Wellington. This research was conducted under permits from the New Zealand Department of Conservation (WE/31248/FAU) and the Victoria University of Wellington Animal Ethics Committee (\#26711). Additional permits were attained from Wellington City Council for work conducted on Miramar Peninsula, and from Zealandia Ecosanctuary for research carried out within the sanctuary. I am grateful to Danielle Shanahan and Ellen Irwin for organising access to the sanctuary, and for answering all my silly questions!

I would like to say a very big thank you to the Department of Conservation staff who made this work possible. Thank you to Nick Fisentzidis and Genevieve Spargo for organising transport and accommodation for my fieldwork on Mana Island, and to Evan Ward and Jeff Hall for organising accommodation for my fieldwork on Matiu/Somes Island. I am also grateful to Leon 
Berard and Otis Berard for putting up with me while I was trapesing around Wellington's offshore islands - thank you both for answering my endless questions about wildlife.

A big thank you to those who joined me during fieldwork. I am extremely grateful to Lily Chizmar and Lin Lin Liu for accompanying me on my extended trips to Matiu/Somes Island. Thank you to Bex Kidson and Nicole Riley for making time for me when I needed assistance, even if it was with only one day's notice! Thank you to Courtney O'Hare, Ronja Hauke, and Tia Gillies for giving your time to help with this project.

During my time at Victoria University I was lucky enough to make some really awesome friends. I am so grateful to Aanchal Singh, Bex Kidson, Dayanitha Damodaran, and Nicole Riley for creating a safe space for me during postgraduate studies. You all put up with my endless talking (and occasional crying) and were always available for advice or comfort, and for that I am so thankful. I would not have made it through without the support of my other fellow students: Baylee Wade, Caitlyn Shannon, Jenna Mumford, Li Yeoh, Ronja Hauke, and Rossella Nicolai Angeletti. Thank you all for your friendship and for being a part of this journey. I would also like to thank my flatmates Alex Duff, Fergus Barker, and Stephen Whitaker for putting up with me whilst I was in my final throes of thesis editing - I know it could not have been easy!

The final thanks belong to my family. Thank you to my Dad for always being on the other end of the line, whether that be for long phone calls or endless editing, you were a rock throughout both of my degrees. To my Mum, thank you for your unwavering love and support, and for checking in on me when I forget to call! 


\begin{abstract}
Wildlife management is fraught with challenges due to the complexities of community ecology. Interventions aimed at restoring ecosystems, or managing species, can have unintended negative outcomes for target species. The effect of avian predation on native lizard fauna in New Zealand is not clearly understood, despite birds being regarded as top predators within mammal-free ecosystems. At least thirty-one species of bird have been recorded preying on native lizards, but few studies have directly addressed avian predation on lizards, with the majority of evidence sourced from published anecdotes. New Zealand's herpetofauna are already vulnerable due to range contractions resulting from mammalian predation and habitat loss, with $87 \%$ of New Zealand lizard species considered 'At Risk' or 'Threatened'. Understanding the risks posed to lizards will help to inform successful management of vulnerable populations.
\end{abstract}

I used lizard-mimicking replicas to identify and assess predation rates exerted by bird species on lizard populations within the Wellington region of New Zealand. I examined the use of lizard replicas as a tool to quantify predation by examining how birds interacted with replicas and comparing attack rates with novel items simultaneously placed in the field. I determined which bird species were preying on replicas, the extent of such predation, and whether site vegetation or daily weather influenced the probability of avian attack on replicas. Although attack frequency did not differ between novel items and lizard replicas, birds exhibited a realistic predatory response by preferentially attacking the head of lizard replicas. Interactions by birds with lizard-mimicking replicas cannot be confirmed as true predation attempts, but lizard replicas can nevertheless be used to quantify predation pressures exerted on lizard populations by opportunistic bird species.

Seven ground-foraging bird species were found to attack lizard replicas. Two species, the pūkeko (Porphyrio melanotus melanotus) and southern black-backed gull (Larus dominicanus dominicanus), were identified as high impact species. The average predation risk experienced by lizard replicas varied greatly across environments, with $0-25 \%$ of replicas attacked daily at sites. Canopy cover and daily rainfall were not significant predictors, but potentially decreased the likelihood of replica attack. Predation risk varied for lizard replicas as a result of 
differing assemblages of bird predators at sites, and the presence and foraging behaviour of specific predatory birds.

Predation by birds is likely to be an issue where predation pressure is high, or lizard populations are small, range restricted, or recovering from the presence of mammalian predators. When managing vulnerable lizard populations, managers should take into account the threats posed by avian predators so that lizard communities can recover successfully following the same trajectory as native birds. 


\section{Table of Contents}

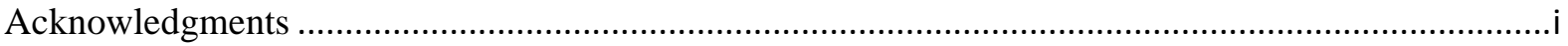

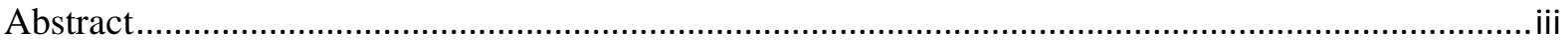

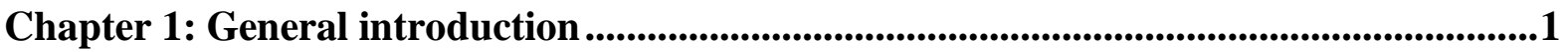

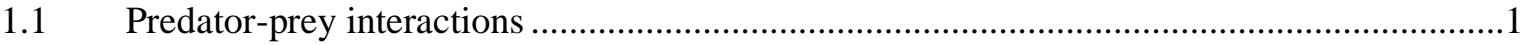

1.2 The introduction and control of mammalian predators in New Zealand .............................3

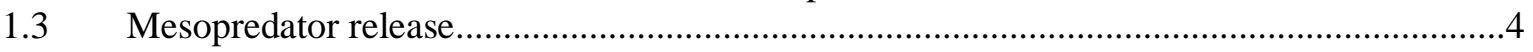

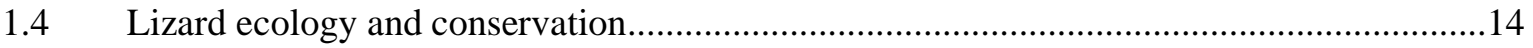

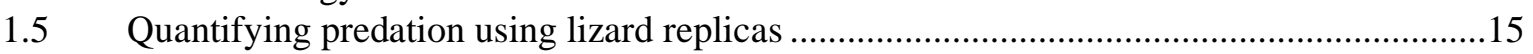

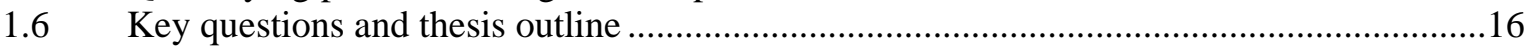

Chapter 2: Assessing the use of lizard-mimicking replicas to quantify avian predation on lizards in New Zealand ..........................................................................................................17

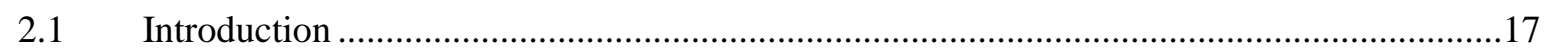

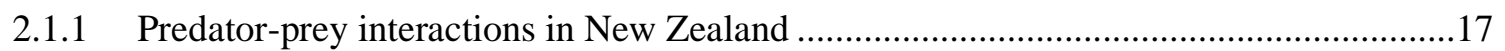

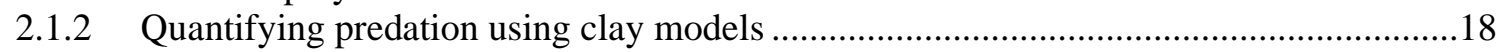

2.1.3 Importance of quantifying predation on lizards ............................................................

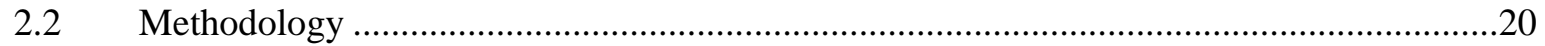

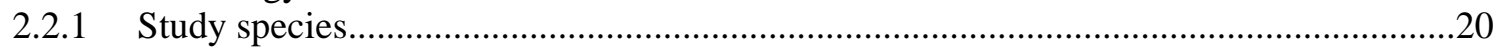

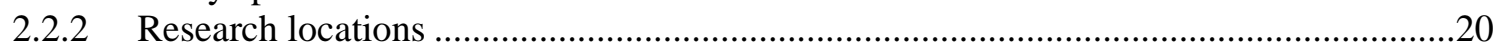

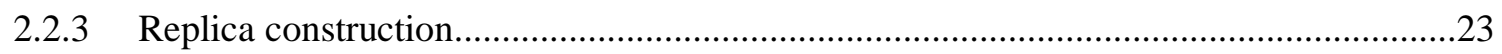

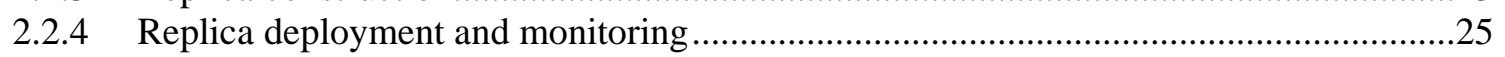

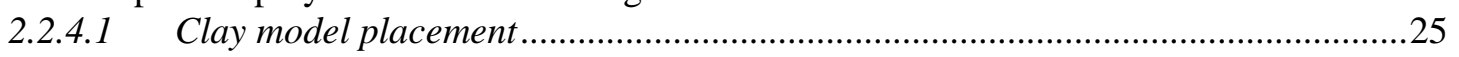

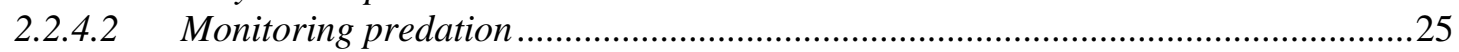

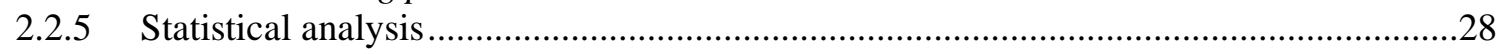

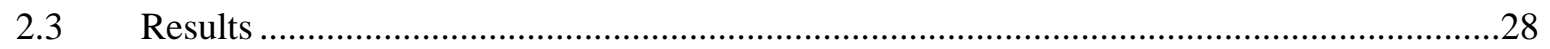

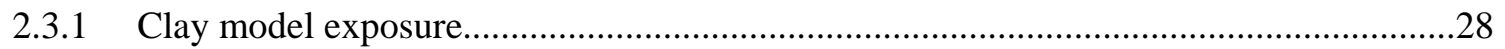

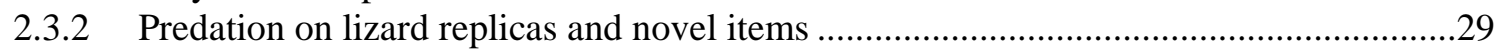

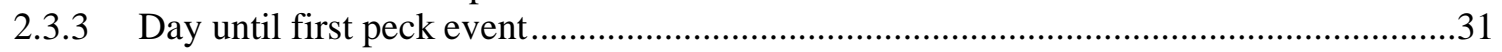

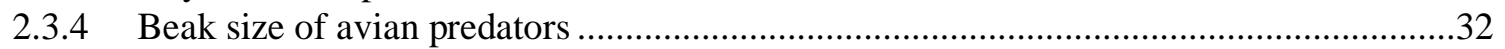

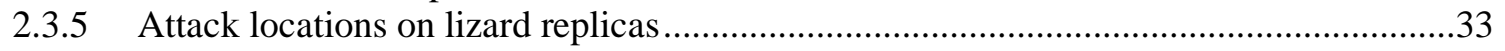

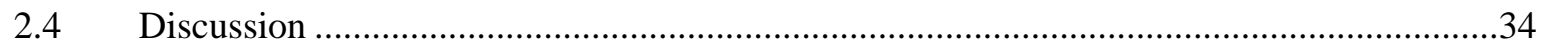

Chapter 3: Habitat factors influencing the predation risk to lizards by birds in

Wellington, New Zealand .................................................................................................................41

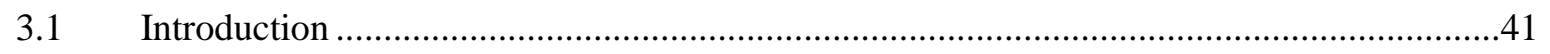

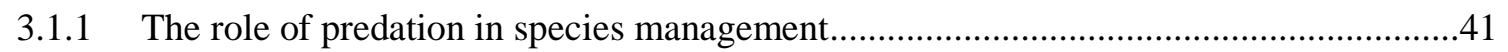

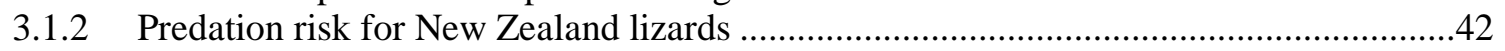

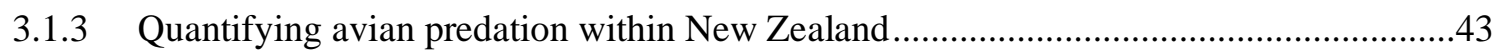

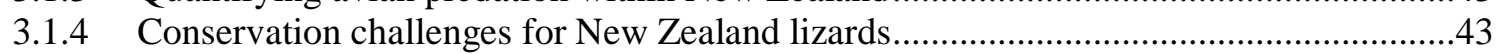

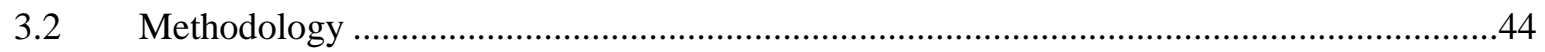

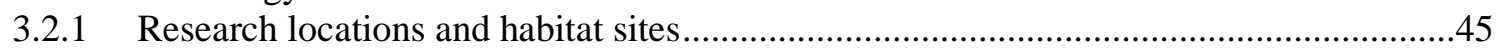

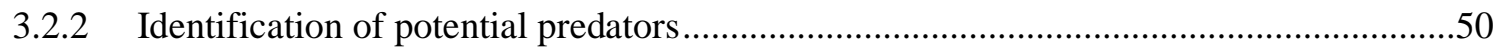

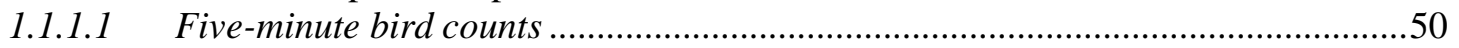

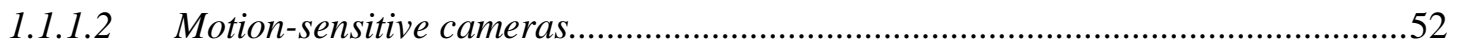

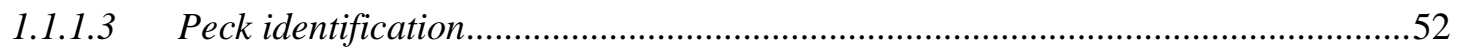

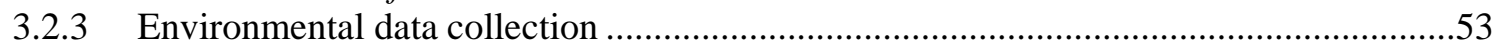

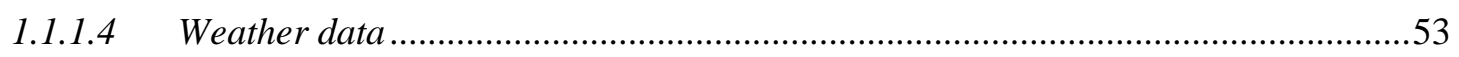

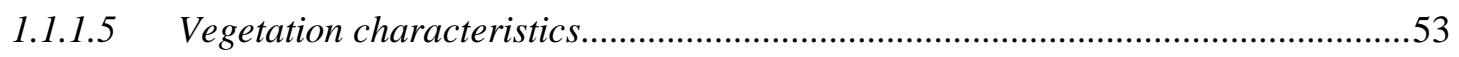

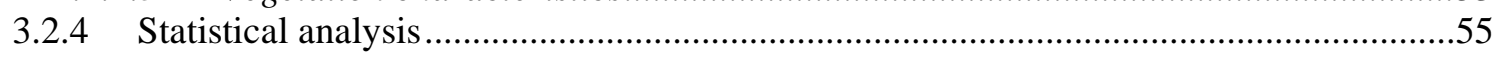




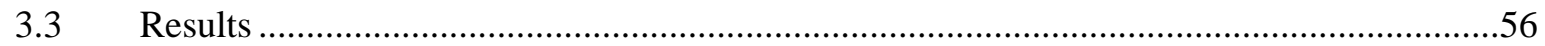

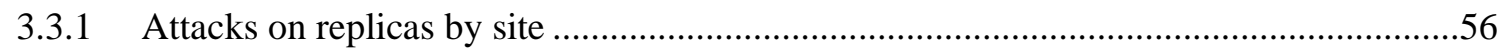

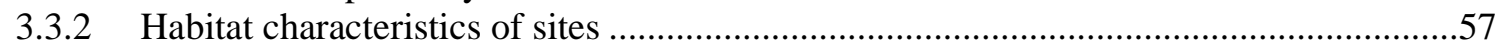

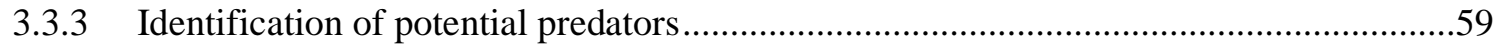

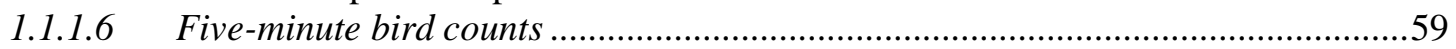

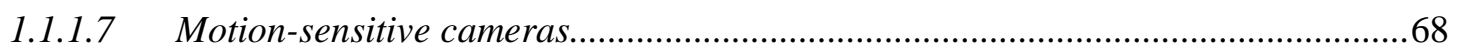

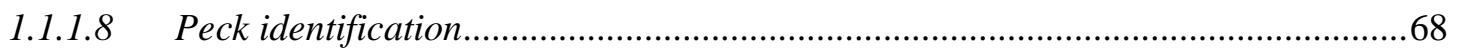

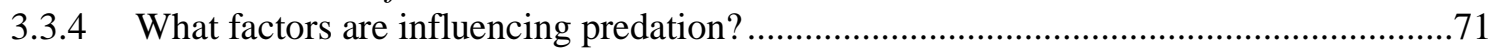

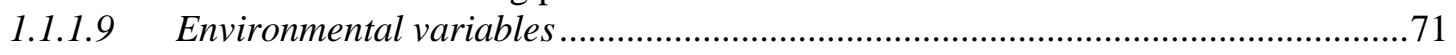

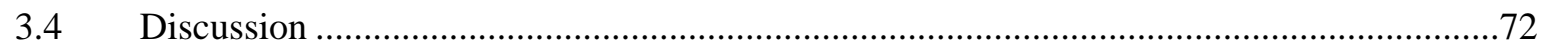

Chapter 4: General summary and implications..............................................................

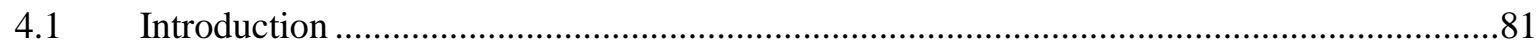

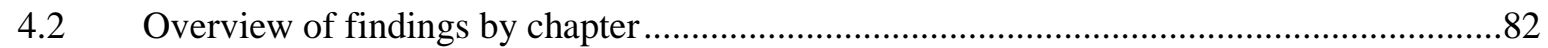

4.2.1 Chapter 2: Assessing the use of lizard-mimicking replicas to quantify avian predation on lizards in New Zealand

4.2.2 Chapter 3: Habitat factors influencing the predation risk to lizards by birds in

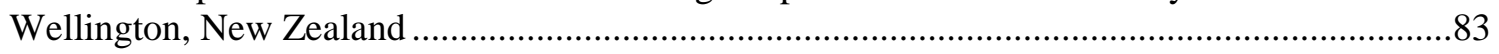

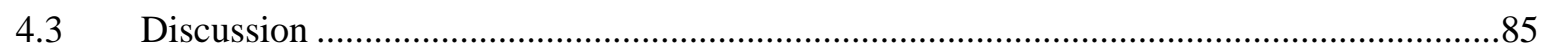

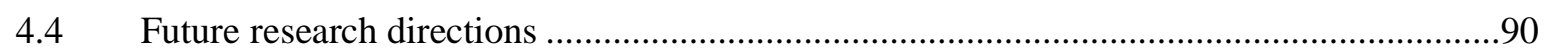

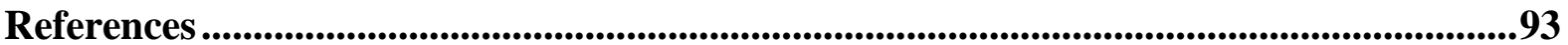




\section{Chapter 1: General introduction}

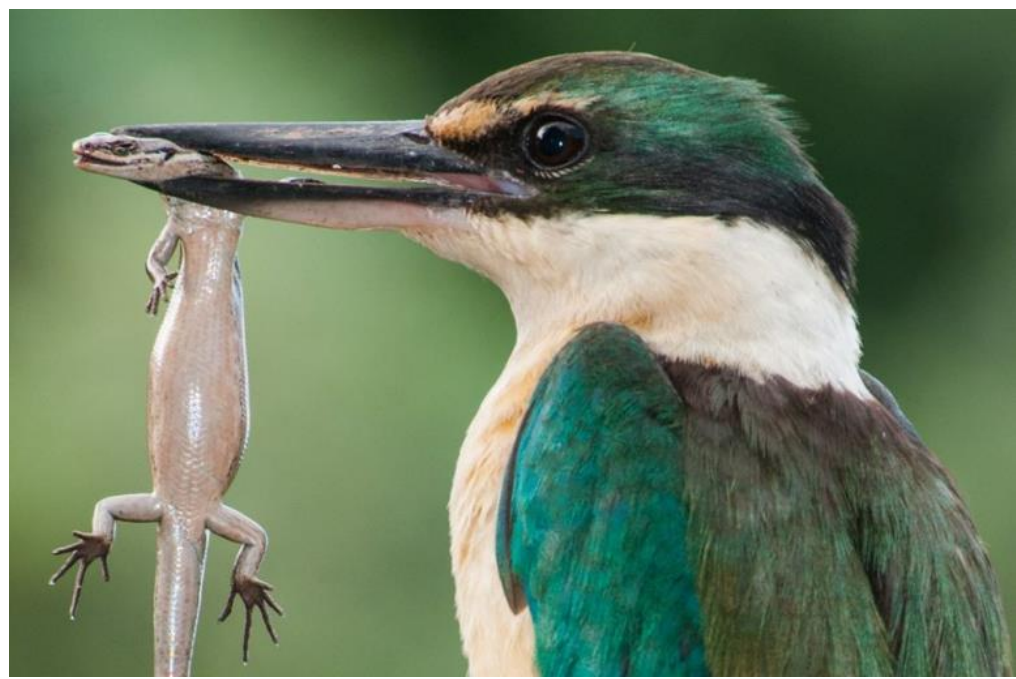

A New Zealand kingfisher (Todiramphus sancta vagans) with a moko skink (Oligosoma moco) in its beak.

Photographed and approved for use by (c)Simon Fordham / NaturePix.

Ecological communities comprise a complex network of species interactions (Carrara et al. 2015). The alteration of any species interaction, whether through species introduction or removal, or a change in population distribution or abundance, can have cascading effects throughout the ecosystem (Huffaker 1958; Paine 1966; Estes \& Palmisano 1974; Simberloff et al. 2013). These effects can be hard to predict due to the complexity and enormity of food webs, and the dynamic nature of species interactions (Menge 1995; Zavaleta et al. 2001). Predicting and understanding the outcomes of altering species interactions within an environment can be vital for preventing future ecological disturbances. I will investigate the threats imposed by predatory birds on New Zealand's lizard fauna to fill the knowledge gap surrounding successful conservation of vulnerable lizard populations within mammal-free environments.

\subsection{Predator-prey interactions}

Predator-prey interactions have long intrigued scholars because of their fundamental role in ecosystem function (Hooper et al. 2005). Predation is the direct interaction between predator and prey, resulting in the death or injury of prey (Menge 1995; Lima 1998). By acting as a 
selective agent on prey abundance and distribution, predation acts as a structuring mechanism within biotic communities (Huffaker 1958; Paine 1966; Estes \& Palmisano 1974). Historically, predator-prey interactions and their resultant effects on both predator and prey populations have been modelled simplistically using one-predator one-prey systems (e.g. Lotka-Volterra). Recently, there have been attempts to incorporate increasing biological complexity within these models, such as the inclusion of multiple predator or prey species. However, we are still largely unsure of the effects that particular species have on each other and how these may be altered when predator-prey interactions are interrupted. For example, predator species can occupy multiple levels of a trophic system. Apex predators, occupying the top trophic level, can suppress predators present on lower trophic levels, i.e. mesopredators (Crooks \& Soulé 1999; Ritchie \& Johnson 2009). Consequently, the removal of predators from a system can result in a plethora of effects, including mesopredator or competitive release (Zavaleta et al. 2001; Ruscoe et al. 2011). Accordingly, a full understanding of predator-prey interactions is required before implementing conservation or wildlife management in order to avoid unintended detrimental effects to any species population (Ritchie \& Johnson 2009). For example, following the removal of larger mammalian predators, the mouse population within Zealandia Ecosanctuary in New Zealand, increased to numbers far higher (32 - 82.7 mice / 100 trap nights) than those reported during pre-eradication surveys (0.2 mice / 100 trap nights) (Watts et al. 2014). This illustrates the importance of identifying and understanding predator-prey interactions at all levels of the food web to predict the consequences of altering species interactions in an environment.

The movement of species around the world has been aided by increased human globalisation (Hulme 2009; Russell 2014; Brenton-Rule et al. 2016). Alien species are now considered an agent of global change due to their pervasive nature and are implicated in widespread biodiversity loss (Vitousek et al. 1996; Salo et al. 2007). Introducing novel predators to an environment can have devastating effects for native species (Towns \& Daugherty 1994). Prey species are often more robust to predation from natural predators for which they have evolved anti-predator traits and behaviours (Salo et al. 2007; Sih et al. 2010). On the other hand, introduced species, devoid of natural predators and competitors, are able to flourish in a system of naïve prey (Sih et al. 2010). Native species that are unable to adapt show population declines which, in extreme cases, can lead to extinction (Towns \& Daugherty 1994). For example, the introduction of the predacious brown tree snake (Boiga irregularis) to the island of Guam led to the extirpation of at least 12 species, and the functional loss of vertebrates across most of 
the ecosystem (Wiles et al. 2003; Rodda \& Savidge 2007). The native fauna, having evolved in isolation from predatory snakes, were ill-equipped to survive the resulting predation pressure from these novel predators (Wiles et al. 2003). Changes in predator-prey interactions resulting from the introduction of predatory species can lead to fragile or functionally extinct ecosystems. It is important we understand how ecosystems change as a result of species introductions in order to weigh the benefits and risks of further altering these systems.

\subsection{The introduction and control of mammalian predators in New Zealand}

Due to a long and isolated evolutionary history, New Zealand has high levels of species endemism and is considered a global biodiversity hotspot (Myers et al. 2000). The native fauna evolved in the absence of terrestrial mammals (with the exception of insectivorous bats); instead, birds and reptiles dominated the food chain (Daugherty et al. 1993; Gibbs 2010). Unlike olfactory-sensing mammals, these natural predators rely on visual cues to detect and hunt prey. As a result, native species evolved traits such as crypsis, and chemical signalling that would later increase their susceptibility to introduced mammalian predators (Daugherty et al. 1993; O'Donnell 1996; Gibbs 2010). Since the first introduction of mammalian predators 700 years ago, New Zealand has lost nearly half of all recorded native vertebrate species (Wilmshurst et al. 2008; Russell et al. 2015; Owens 2017). Furthermore, invasive mammals have been implicated in population declines of all major terrestrial groups within the country: birds (Bell et al. 2016), bats (Pryde et al. 2005), reptiles and amphibians (Towns \& Daugherty 1994), invertebrates (Watts et al. 2011), and plants (Towns et al. 2013). Consequently, mammalian predator eradication and suppression are two of the primary tools used to conserve native species within the country (Towns et al. 2013; Parkes et al. 2017b).

New Zealand is leading the world in island eradications and is currently home to a fifth of all offshore islands involved with introduced species eradications globally (Russell \& Broome 2016; Owens 2017). Islands are specifically targeted as they allow the complete removal of novel species and offer reduced likelihood of reinvasion (Parkes et al. 2017a; Bell et al. 2019). Accordingly, island reserves are considered ecologically significant refugia for species that are threatened with extinction on the mainland (Bellingham et al. 2010). However, predator-free islands represent less than $0.01 \%$ of New Zealand's available land area (Parkes et al. 2017b; Bell et al. 2019). As a result, the Predator Free New Zealand campaign was proposed in 2012 to restore biodiversity across the country (Russell et al. 2015; Owens 2017). Eight species were 
targeted for eradication to meet this goal: the ship rat (Rattus rattus), Norway rat ( $R$. norvegicus), kiore (R. exulans), house mouse (Mus musculus), ferret (Mustela furo), stoat (M. erminea), weasel (M. nivalis), and brushtail possum (Trichosurus vulpecula) (Russell et al. 2015; Owens 2017). An additional intermediary policy, Predator Free 2050, was announced by the New Zealand government in 2016, which aimed to rid the country of the 'most damaging' predators ( $R$. rattus, $R$. norvegicus, $M$. furo, M. erminea, $M$. nivalis and $T$. vulpecula) by the year 2050 (Owens 2017; Parkes et al. 2017a).

Eradicating predators from environments alters the abundance and composition of species within an ecosystem (Paine 1966; Estes \& Palmisano 1974; Ramsey \& Norbury 2009). The eradication of mammalian predators will likely set ecosystems on a new trajectory, one of recovery, but the effects of this will be difficult to predict (Ramsey \& Norbury 2009). Researchers recognise the need to understand multispecies interactions when eradicating introduced species (e.g. Zavaleta et al. 2001; Ramsey \& Norbury 2009; Ruscoe et al. 2011). However, the majority of past eradications have taken place on small islands, where only simple predator-prey interactions exist (Linklater \& Steer 2018). While ecosanctuaries offer the unique opportunity to monitor eradication effects on ecosystems, this only occurs on a small scale (Watts et al. 2014). On larger scales, effects may be complicated by the spatial variation of introduced predator populations within the New Zealand mainland, and this is something we would not see as a result of fine-scale control (Towns \& Daugherty 1994).

\subsection{Mesopredator release}

The eradication of mammalian predators has been employed to aid the recovery of endemic lizard populations as well as to aid the success of translocations (Baling et al. 2013; Towns et al. 2013; Monks et al. 2014). It is generally well accepted that mammal control is successful in aiding the recovery of lizard species on islands and birds within mainland sanctuaries (Whitaker 1973; Towns 1996; Nelson et al. 2016; Miskelly 2018). However, on several occasions pest-control has proven to be an insufficient protection measure for lizard populations due to mesopredator release (Ramsey \& Norbury 2009; Dumont 2015). For example, a decade of mammal control at Nelson Lakes National Park resulted in no detectable recovery of lizard populations, with populations showing ongoing decline despite an obvious recovery of native avian populations (Dumont 2015). Additionally, by modelling species interactions in a grassland ecosystem, Ramsey \& Norbury (2009) established that pest control 
alone was unable to boost lizard populations. Mice, that were unable to be sufficiently controlled during the eradication attempt, were considered the root cause, but this was discredited when mouse control was included within the model and lizard populations still failed to respond (Ramsey \& Norbury 2009). A secondary hypothesis offered was an increase in avian predation on lizard populations as a result of mammal control (Ramsey \& Norbury 2009).

Literature detailing mesopredator release focuses heavily on the release of mammalian species (e.g. Crooks \& Soulé 1999; Ritchie \& Johnson 2009; Ruscoe et al. 2011). However, within New Zealand, birds are natural predators of native species (Daugherty et al. 1993; Gibbs 2010). Predation by invasive mammals is the foremost cause of population suppression of native birds in New Zealand (Innes et al. 2010). When mammal control occurs, bird populations are able to rebound and can often reach higher population densities than those sympatric with mammalian predators, effectively resulting in the mesopredator release of native bird predators (Innes et al. 2010). Many of New Zealand's bird species are generalist feeders, with little to no dietary specialisation (O’Donnell \& Dilks 1994). Generalist predators can exert significant top-down control on small populations and this offers particular risk to lizard populations recovering from the presence of predatory mammals, as they may be very small and therefore vulnerable (Polis \& Strong 1996; Kross et al. 2013). Avian predators are generally not considered within predator complexes within New Zealand (e.g. Figure 2 in Ritchie \& Johnson 2009). Even when they are included, they are considered important predators of invertebrates, but not other small organisms such as herpetofauna (Ramsey \& Norbury 2009).

Globally, birds are recognised as key predators of lizards (Martin \& Lopez 1996). Within New Zealand, predation of native lizards by natural predators, birds and reptiles, is under-researched and little is known about the effects of these predator-prey dynamics on lizard fauna (van Winkel \& Ji 2012). At least 31 bird species have been recorded preying on lizards within New Zealand (Table 1.1). However, the majority of observations are anecdotal and are the result of opportunistic data collection: one-off observations of predation events, finding remains at nest sites or within birds during necropsies, or records of lizard presence within the diet of bird species (Table 1.1). 
Although previous reports have identified the need to explore threats posed by opportunistic bird predators, very little research has been conducted to understand and quantify their impacts on New Zealand's lizards (Towns 1999; Gardner-Gee et al. 2007; van Winkel 2008). Only three previous studies have investigated lizard predation by birds, but these studies focused on specific predator or prey species. Although many observations of lizard predation by the New Zealand kingfisher (Todiramphus sanctus vagans) exist within the literature (Table 1.1), the potential impact of this species on lizards has only recently been quantified, with lizard remains in $88 \%$ and $43 \%$ of regurgitated pellets produced by kingfishers on Tiritiri Matangi and Motuora Islands, respectively (van Winkel 2008). Lizards were found in high densities on these offshore islands, and as a result likely form a key component of the diet of local kingfishers (van Winkel 2008). In comparison, although identified as occasional predators of lizards (Table 1.1), no lizard remains were found in regurgitated pellets from swamp harriers (Circus approximans) or morepork (Ninox novaeseelandiae novaeseelandiae) on the same islands (van Winkel 2008). The two other studies focusing on predation by birds looked at the influence of bird attack on the survival or natural selection of lizard species. Schneyer (2001) used avian exclusion netting to identify whether predation by birds altered the survival rates of a translocated population of jewelled gecko, Naultinus gemmeu. However, survival rates did not differ between lizards located inside or outside of the exclusion netting. Baling (2017), used $3 \mathrm{D}$-printed lizard replicas to identify whether attack frequency on colour morphs of the shore skink, Oligosoma smithi, differed across simple and complex backgrounds. While the background did not seem to significantly influence predation rates by birds, patterned morphs of the skink, which were more common in the environment, received a higher frequency of attacks than skinks with no pattern (Baling 2017). Consequently, although these studies have been helpful in furthering our knowledge surrounding the threats bird species pose to New Zealand lizard populations, no research has attempted to quantify the predation pressure experienced by the lizard populations themselves. 
Table 1.1: Records of predation on native lizards by avian species within New Zealand (modified from Hare et al. 2016). The current binomial classification for each New Zealand bird species was gathered from Robertson et al. (2017). Bold text denotes native avian species. 'Stomach content' encompasses stomach, crop, and gizzard analyses. 'Direct obs.' indicates a direct observation of predation by a person or group. 'Reported in diet' indicates that predation was reported in the literature but not directly witnessed. Where possible, the identified lizard prey have been classified to their current taxonomy. Location of predation event is reported when provided in the literature.

\begin{tabular}{|c|c|c|c|c|c|}
\hline Order & Species & Evidence & Identified prey & Location & Reference \\
\hline \multirow[t]{5}{*}{ Accipitriformes } & \multirow{5}{*}{$\begin{array}{l}\text { Swamp harrier } \\
\text { (Circus } \\
\text { approximans) }\end{array}$} & Reported in diet & Lizard & & (Heather \& Robertson 1996) \\
\hline & & Food pellets & O. maccanni & $\begin{array}{l}\text { MacKenzie Basin, } \\
\text { Canterbury }\end{array}$ & (Pierce \& Maloney 1989) \\
\hline & & Stomach content & Lizard & Unk. & (Redhead 1969) \\
\hline & & Reported in diet & Lizard & & (Oliver 1955) \\
\hline & & Reported in diet & Lizard & & (Buddle 1951) \\
\hline Anseriformes & $\begin{array}{l}\text { Goose sp. } \\
(\text { Unk.) }\end{array}$ & Reported in diet & Lizard & Macraes Flat, Otago & (de Hamel \& McInnes 1971) \\
\hline Casuariiformes & $\begin{array}{l}\text { North Island } \\
\text { brown kiwi } \\
\text { (Apteryx mantelli) }\end{array}$ & $\begin{array}{l}\text { Direct obs. } \\
\text { Photograph }\end{array}$ & Skink & $\begin{array}{l}\text { Little Barrier Island, } \\
\text { Hauraki Gulf }\end{array}$ & (Savoca et al. 2018) \\
\hline \multirow[t]{6}{*}{ Charadriiformes } & \multirow{4}{*}{$\begin{array}{l}\text { Black-fronted } \\
\text { tern } \\
\text { (Chlidonias } \\
\text { albostriatus) }\end{array}$} & Direct obs. & O. polychroma & $\begin{array}{l}\text { Eglinton Valley, } \\
\text { Fiordland }\end{array}$ & (O’Donnell \& Hoare 2009) \\
\hline & & Direct obs. & Skink & Awarua Bay, Southland & (Cooper 2001) \\
\hline & & $\begin{array}{l}\text { Direct obs. } \\
\text { Photograph }\end{array}$ & Skink & Ahuriri River, Canterbury & (Lalas 1977) \\
\hline & & Reported in diet & Lizard & & (Oliver 1955) \\
\hline & $\begin{array}{l}{ }^{\mathrm{v}} \text { Gull-billed tern } \\
\text { (Gelochelidon } \\
\text { nilotica) } \\
\end{array}$ & Reported in diet & Lizard & & (Oliver 1955) \\
\hline & $\begin{array}{l}\text { Red-billed gull } \\
\text { (Larus } \\
\text { novaehollandiae } \\
\text { scopulinus) }\end{array}$ & Reported in diet & Lizard & & (Oliver 1955) \\
\hline
\end{tabular}




\begin{tabular}{|c|c|c|c|c|c|}
\hline Order & Species & Evidence & Identified prey & Location & Reference \\
\hline & \multirow{2}{*}{$\begin{array}{l}\text { Southern black- } \\
\text { backed gull } \\
\text { (Larus dominicanus } \\
\text { dominicanus) }\end{array}$} & Reported in diet & Lizard & & (Heather \& Robertson 1996) \\
\hline & & Reported in diet & Small reptile & & $\begin{array}{l}\text { (Powlesland \& Robertson } \\
\text { 1987) }\end{array}$ \\
\hline \multirow[t]{5}{*}{ Ciconiiformes } & $\begin{array}{l}\text { Australasian } \\
\text { bittern } \\
\text { (Botaurus } \\
\text { poiciloptilus) } \\
\end{array}$ & Reported in diet & Lizard & & (Buddle 1951) \\
\hline & $\begin{array}{l}\text { Reef heron } \\
\text { (Egretta sacra } \\
\text { sacra) } \\
\end{array}$ & Direct obs. & $\begin{array}{l}\text { Gecko } \\
\text { Skink }\end{array}$ & $\begin{array}{l}\text { Stephens Island, } \\
\text { Marlborough Sound }\end{array}$ & (Mander 1972) \\
\hline & \multirow{3}{*}{$\begin{array}{l}\text { White-faced } \\
\text { heron } \\
\text { (Egretta } \\
\text { novaehollandiae) }\end{array}$} & Direct obs. & Lizard & $\begin{array}{l}\text { Motonau Island, } \\
\text { Canterbury }\end{array}$ & (Crossland \& Freeman 1995) \\
\hline & & Direct obs. & O. nigriplantare & $\begin{array}{l}\text { South East Island, } \\
\text { Chatham Island }\end{array}$ & (Nilsson et al. 1994) \\
\hline & & Direct obs. & Skink & $\begin{array}{l}\text { Lake Wainono, } \\
\text { Canterbury }\end{array}$ & (Pierce 1980) \\
\hline \multirow[t]{6}{*}{ Coraciiformes } & $\begin{array}{l}\text { Laughing } \\
\text { kookaburra } \\
\text { (Dacelo } \\
\text { novaeguineae) } \\
\end{array}$ & Reported in diet & Lizard & & (Oliver 1955) \\
\hline & \multirow{5}{*}{$\begin{array}{l}\text { New Zealand } \\
\text { kingfisher } \\
\text { (Todiramphus } \\
\text { sanctus vagans) }\end{array}$} & $\begin{array}{l}\text { Food pellets } \\
\text { Direct obs. } \\
\text { Remains at nest site }\end{array}$ & O. moco & $\begin{array}{l}\text { Tiritiri Matangi Island } \\
\text { and Motuora Island, } \\
\text { Hauraki Gulf }\end{array}$ & $\begin{array}{l}\text { (van Winkel 2008; van } \\
\text { Winkel \& Ji 2012) }\end{array}$ \\
\hline & & Reported in diet & Skink & $\begin{array}{l}\text { Tiritiri Matangi Island, } \\
\text { Hauraki Gulf }\end{array}$ & (Reid 2009) \\
\hline & & Direct obs. & Skink & Taieri Ferry, Otago & (Morrison \& Morrison 2002) \\
\hline & & Direct obs. & Skink & Hutt River, Wellington & $($ Gibb 2000) \\
\hline & & Reported in diet & Lizard & & (Heather \& Robertson 1996) \\
\hline
\end{tabular}


CHAPTER 1: GENERAL INTRODUCTION

\begin{tabular}{|c|c|c|c|c|c|}
\hline Order & Species & Evidence & Identified prey & Location & Reference \\
\hline & & $\begin{array}{l}\text { Food pellets } \\
\text { Direct obs. } \\
\text { Remains at nest site }\end{array}$ & $\begin{array}{l}\text { M. granulatus } \\
\text { Skink }\end{array}$ & $\begin{array}{l}\text { Orongorongo Valley, } \\
\text { Wellington }\end{array}$ & (Fitzgerald et al. 1986) \\
\hline & & Direct obs. & Skink & Unk. & (Moon 1986) \\
\hline & & Food pellets & Skink & $\begin{array}{l}\text { Oruatapu Reserve, } \\
\text { Taumarunui }\end{array}$ & (O’Donnell 1981) \\
\hline & & Reported in diet & Lizard & & (Falla et al. 1978) \\
\hline & & Direct obs. & Lizard & $\begin{array}{l}\text { Urewera Ranges, Bay of } \\
\text { Plenty }\end{array}$ & (St. Paul \& McKenzie 1977) \\
\hline & & Direct obs. & Gecko & Unk. & (Scarlett 1972) \\
\hline & & Direct obs. & Skink & Clevedon, Auckland & (McKenzie 1955) \\
\hline & & $\begin{array}{l}\text { Reported in diet } \\
\text { Photograph }\end{array}$ & Lizard & & (Oliver 1955) \\
\hline & & Direct obs. & Skink & $\begin{array}{l}\text { Fletchers Bay, } \\
\text { Coromandel }\end{array}$ & (Edwards 1952) \\
\hline & & Remains at nest site & Lizard & $\begin{array}{l}\text { Great Barrier Island, } \\
\text { Hauraki Gulf }\end{array}$ & (Roberts 1952) \\
\hline & & Direct obs. & Lizard & Kapiti Island, Wellington & $\begin{array}{l}\text { (Wilkinson \& Wilkinson } \\
\text { 1952) }\end{array}$ \\
\hline & & Direct obs. & Lizard & $\begin{array}{l}\text { Little Barrier Island, } \\
\text { Hauraki Gulf }\end{array}$ & (Sibson 1949) \\
\hline & & Direct obs. & Lizard & $\begin{array}{l}\text { Whakarewarewa and } \\
\text { Kaingaroa Forests, } \\
\text { Waikato }\end{array}$ & (Weeks 1949) \\
\hline & & Direct obs. & Lizard & Whanganui & (Mead 1947) \\
\hline \multirow[t]{2}{*}{ Cuculiformes } & \multirow{2}{*}{$\begin{array}{l}\text { Long-tailed } \\
\text { cuckoo } \\
\text { (Eudynamys } \\
\text { taitensis) }\end{array}$} & Stomach content & Gecko & $\begin{array}{l}\text { Unk. - opportunistic } \\
\text { necropsies }\end{array}$ & (Gill et al. 2018) \\
\hline & & Reported in diet & $\begin{array}{l}\text { Gecko } \\
\text { Skink }\end{array}$ & & (Reid 2009) \\
\hline
\end{tabular}




\begin{tabular}{|c|c|c|c|c|c|}
\hline Order & Species & Evidence & Identified prey & Location & Reference \\
\hline & & Reported in diet & $\begin{array}{l}\text { Gecko } \\
\text { Skink }\end{array}$ & & (Heather \& Robertson 1996) \\
\hline & & Reported in diet & Skink & Kapiti Island, Wellington & (Falla et al. 1978) \\
\hline & & Reported in diet & Lizard & & (Oliver 1955) \\
\hline & & Direct obs. & Lizard & Kapiti Island, Wellington & $\begin{array}{l}\text { (Wilkinson \& Wilkinson } \\
\text { 1952) }\end{array}$ \\
\hline \multirow[t]{7}{*}{ Falconiformes } & \multirow{3}{*}{$\begin{array}{l}{ }^{\mathbf{v}} \text { Nankeen kestrel } \\
\text { (Falco cenchroides } \\
\text { cenchroides) }\end{array}$} & Reported in diet & Lizard & & (Heather \& Robertson 1996) \\
\hline & & Direct obs. & Lizard & Lees Valley, Canterbury & (Edgar \& Grant 1969) \\
\hline & & Reported in diet & Lizard & & (Oliver 1955) \\
\hline & \multirow{4}{*}{$\begin{array}{l}\text { New Zealand } \\
\text { falcon } \\
\text { (Falco } \\
\text { novaeseelandiae } \\
\text { spp.) }\end{array}$} & $\begin{array}{l}\text { Remains at nest site } \\
\text { Video capture }\end{array}$ & $\begin{array}{l}\text { Woodworthia sp. } \\
\text { Skink }\end{array}$ & Marlborough Region & (Kross et al. 2013) \\
\hline & & $\begin{array}{l}\text { Food trial } \\
\text { Food pellets } \\
\text { Stomach content }\end{array}$ & $\begin{array}{l}\text { Gecko } \\
\text { Skink }\end{array}$ & $\begin{array}{l}\text { Pirinoa, South Wairarapa } \\
\text { South Island }\end{array}$ & (Fox 1977) \\
\hline & & Reported in diet & Lizard & & (Oliver 1955) \\
\hline & & Reported in diet & Lizard & & (Buller 1882) \\
\hline \multirow[t]{2}{*}{ Galliformes } & $\begin{array}{l}\text { Chicken } \\
\text { (Gallus gallus spp.) }\end{array}$ & Direct obs. & $\begin{array}{l}\text { O. aeneum } \\
\text { O. polychroma }\end{array}$ & Wellington & (Bell 1996) \\
\hline & $\begin{array}{l}\text { Indian peafowl } \\
\text { (Pavo cristatus) }\end{array}$ & Reported in diet & Small reptiles & & (Oliver 1955) \\
\hline \multirow[t]{3}{*}{ Gruiformes } & $\begin{array}{l}\text { Banded rail } \\
\text { (Gallirallus } \\
\text { philippensis } \\
\text { assimilis) }\end{array}$ & Direct obs. & Lizards & $\begin{array}{l}\text { Poor Knights Islands, } \\
\text { Northland }\end{array}$ & (Whitaker 1986) \\
\hline & $\begin{array}{l}\text { Weka } \\
\text { (Gallirallus } \\
\text { australis } \text { spp.) } \\
\end{array}$ & Reported in diet & Reptiles & & (Heather \& Robertson 1996) \\
\hline & $\begin{array}{r}\text { Western } \\
\text { (G. a. australis) }\end{array}$ & Stomach content & Lizard & $\begin{array}{l}\text { Central Westland, South } \\
\text { Island }\end{array}$ & (Coleman et al. 1983) \\
\hline
\end{tabular}




\begin{tabular}{|c|c|c|c|c|c|}
\hline Order & Species & Evidence & Identified prey & Location & Reference \\
\hline & & Reported in diet & Lizard & & (Oliver 1955) \\
\hline & \multirow[b]{2}{*}{$\begin{array}{r}\text { North Island } \\
\text { (G. a. greyi) }\end{array}$} & Reported in diet & Lizard & & (Oliver 1955) \\
\hline & & Reported in diet & Lizard & $\begin{array}{l}\text { Kapiti Island^}{ }^{\wedge} \\
\text { Wellington }\end{array}$ & $\begin{array}{l}\text { (Wilkinson \& Wilkinson } \\
\text { 1952) }\end{array}$ \\
\hline & $\begin{array}{r}\text { Buff } \\
\text { (G. a. hectori) } \\
\end{array}$ & Reported in diet & Lizard & & (Oliver 1955) \\
\hline & $\begin{array}{l}\text { South Island } \\
\text { takahē } \\
\text { (Porphyrio } \\
\text { hochstetteri) } \\
\end{array}$ & Direct obs. & $\begin{array}{l}\text { O. zelandicum } \\
\text { W. maculata }\end{array}$ & $\begin{array}{l}\text { Maud Island, } \\
\text { Marlborough Sounds }\end{array}$ & (Whitaker 1991) \\
\hline & \multirow{4}{*}{$\begin{array}{l}\text { Pūkeko } \\
\text { (Porphyrio } \\
\text { melanotus } \\
\text { melanotus) }\end{array}$} & Feeding trial & O. aeneum & & (van Winkel 2008) \\
\hline & & Stomach content & Lizard & Unk. & $($ Carroll 1966) \\
\hline & & Reported in diet & Lizard & & (Oliver 1955) \\
\hline & & Reported in diet & Lizard & & (Heather \& Robertson 1996) \\
\hline \multirow[t]{7}{*}{ Passeriformes } & $\begin{array}{l}\text { Myna } \\
\text { (Acridotheres tristis) }\end{array}$ & Direct obs. & Lizard & Mount Cargill, Otago & (Eagle 2001) \\
\hline & \multirow{2}{*}{$\begin{array}{l}\text { New Zealand } \\
\text { pipit } \\
\text { (Anthus } \\
\text { novaeseelandiae } \\
\text { novaeseelandiae) }\end{array}$} & Direct obs. & Lizard & Kapiti Island, Wellington & $\begin{array}{l}\text { (Wilkinson \& Wilkinson } \\
\text { 1952) }\end{array}$ \\
\hline & & $\begin{array}{l}\text { Direct obs. } \\
\text { Photograph }\end{array}$ & O. aeneum & $\begin{array}{l}\text { Matakohe Island, } \\
\text { Northland }\end{array}$ & (Ball \& Parrish 2005) \\
\hline & $\begin{array}{l}\text { North Island } \\
\text { fernbird } \\
\text { (Bowdleria punctata } \\
\text { vealeae) }\end{array}$ & Reported in diet & Lizard & & (Heather \& Robertson 1996) \\
\hline & \multirow{3}{*}{$\begin{array}{l}\text { Australian magpie } \\
\text { (Gymnorhina } \\
\text { tibicen) }\end{array}$} & Stomach content & Skink & Christchurch & (Moeed 1976) \\
\hline & & Stomach content & $\begin{array}{l}\text { Gecko } \\
\text { Skink }\end{array}$ & $\begin{array}{l}\text { Unk. - remains sent from } \\
\text { around the country }\end{array}$ & (McIlroy 1968) \\
\hline & & Reported in diet & Lizard & Springfield, Canterbury & (McCaskill 1945) \\
\hline
\end{tabular}


CHAPTER 1: GENERAL INTRODUCTION

\begin{tabular}{|c|c|c|c|c|c|}
\hline Order & Species & Evidence & Identified prey & Location & Reference \\
\hline & & Direct obs. & O. infrapunctatum & $\begin{array}{l}\text { Stephens Island, } \\
\text { Marlborough Sound }\end{array}$ & (Thompson 2000) \\
\hline & \multirow{2}{*}{$\begin{array}{l}\text { Starling } \\
\text { (Sturnus vulgaris) }\end{array}$} & Direct obs. & O. nigriplantare & $\begin{array}{l}\text { South East Island, } \\
\text { Chatham Island }\end{array}$ & (Nilsson et al. 1994) \\
\hline & & Direct obs. & O. aeneum & $\begin{array}{l}\text { Seatoun Heights, } \\
\text { Wellington }\end{array}$ & (Bell 1996) \\
\hline & \multirow{3}{*}{$\begin{array}{l}\text { Blackbird } \\
\text { (Turdus merula) }\end{array}$} & Direct obs. & O. nigriplantare & $\begin{array}{l}\text { South East Island, } \\
\text { Chatham Island }\end{array}$ & (Nilsson et al. 1994) \\
\hline & & Direct obs. & Skink & $\begin{array}{l}\text { South East Island, } \\
\text { Chatham Island }\end{array}$ & (Lovegrove 1981) \\
\hline & & Reported in diet & Lizard & & (Oliver 1955) \\
\hline \multirow[t]{2}{*}{ Psittaciformes } & \multirow{2}{*}{$\begin{array}{l}\text { Kākāpō } \\
\text { (Strigops } \\
\text { habroptilus) }\end{array}$} & Stomach content & Lizard & & (von Hugel 1875) \\
\hline & & Reported in diet & Lizard & & (Heather \& Robertson 1996) \\
\hline \multirow[t]{9}{*}{ Strigiformes } & \multirow{3}{*}{$\begin{array}{l}\text { Little owl } \\
\text { (Athene noctua) }\end{array}$} & Reported in diet & Lizard & & (Oliver 1955) \\
\hline & & $\begin{array}{l}\text { Food pellets } \\
\text { Stomach contents } \\
\text { Remains at nest site }\end{array}$ & Gecko & $\begin{array}{l}\text { Unk. - remains sent from } \\
\text { around the country }\end{array}$ & (Marples 1942) \\
\hline & & Video & $\begin{array}{l}\text { Gecko } \\
\text { Skink }\end{array}$ & $\begin{array}{l}\text { Tiritiri Matangi Island, } \\
\text { Hauraki Gulf }\end{array}$ & (Busbridge \& Stewart 2018) \\
\hline & \multirow{6}{*}{$\begin{array}{l}\text { Morepork } \\
\text { (Ninox } \\
\text { novaeseelandiae } \\
\text { novaeseelandiae) }\end{array}$} & Remains at nest site & Gecko & $\begin{array}{l}\text { Great Island, Three Kings } \\
\text { Islands }\end{array}$ & (Parrish \& Gill 2003) \\
\hline & & Remains at nest site & $\begin{array}{l}\text { Gecko } \\
\text { Skink }\end{array}$ & $\begin{array}{l}\text { Great Island, Three Kings } \\
\text { Islands }\end{array}$ & (Parrish \& Pierce 1997) \\
\hline & & Remains at nest site & Gecko & Hen and Chicken Islands & (Parrish 1997) \\
\hline & & Reported in diet & Lizard & & (Falla et al. 1978) \\
\hline & & Remains at nest site & Gecko & $\begin{array}{l}\text { Great Island, Three Kings } \\
\text { Islands }\end{array}$ & (Ramsay \& Watt 1971) \\
\hline & & Remains at nest site & Gecko & Hen and Chicken Islands & (Chambers et al. 1955) \\
\hline
\end{tabular}




\begin{tabular}{|c|c|c|c|c|c|}
\hline Order & Species & Evidence & Identified prey & Location & Reference \\
\hline & & Reported in diet & Lizard & & (Oliver 1955) \\
\hline & & Remains at nest site & Gecko & $\begin{array}{l}\text { Great Island, Three Kings } \\
\text { Islands }\end{array}$ & (Turbott \& Buddle 1948) \\
\hline & & $\begin{array}{l}\text { Remains at nest site } \\
\text { (fossil) }\end{array}$ & $\begin{array}{l}\text { Hoplodactylus } \\
\text { duvaucelii } \\
\text { Mokopirirakau sp. } \\
\text { Naultinus sp. } \\
\text { Gecko } \\
\text { Skink }\end{array}$ & Gouland Downs, Nelson & (Worthy 2001) \\
\hline & \multirow{3}{*}{$\begin{array}{l}\text { * Laughing owl } \\
\text { (Sceloglaux } \\
\text { albifacies spp.) }\end{array}$} & Reported in diet & Lizard & & (Heather \& Robertson 1996) \\
\hline & & Reported in diet & Lizard & & (Oliver 1955) \\
\hline & & Feeding trial & Lizard & & (Buller 1888) \\
\hline
\end{tabular}

${ }^{v}$ Vagrant species; sporadic presence within New Zealand (Robertson et al. 2017).

^ The weka population on Kapiti Island is believed to be a hybrid of the South Island G. a. australis and the North Island G. a. greyi (Miskelly \& Beauchamp 2004).

*Extinct species. 


\subsection{Lizard ecology and conservation}

Considered highly diverse for a temperate biome, New Zealand's lizard fauna contains over 100 species comprising two families: Diplodactylidae (gecko) and Scincidae (skink) (Hitchmough et al. 2015). Many of these species remain taxonomically indeterminate, and cryptic species are still being identified (Nielsen et al. 2011; Hitchmough et al. 2015). During a long and isolated evolutionary history, lizard species within New Zealand evolved a high prevalence of unusual traits and interactions. For example, $99 \%$ of native lizards are viviparous compared to an estimated $16 \%$ internationally (Cree \& Hare 2016). Some species are also noted as holding functional roles within native ecosystems, such as pollination or seed dispersal (Whitaker 1987; Wotton et al. 2016). However, New Zealand lizards remain understudied and this lack of data is influenced by the distribution of populations (often small and remote) and species characteristics (nocturnal and cryptic) that make ecological studies difficult (Daugherty et al. 1993; Hoare et al. 2007; Hitchmough et al. 2016a, 2016b). For example, the intra-species interactions exhibited by lizards are largely unknown, including interactions relating to social structure and mating (Cree \& Hare 2016). Despite being an integral part of mammal-free ecosystems within New Zealand, the conservation research on reptiles has been overshadowed by avian and mammalian research (Daugherty et al. 1993; Gibbs 2010; Baling et al. 2013; Linklater \& Steer 2018).

New Zealand's herpetofauna have experienced major range reductions as a result of mammalian predation and habitat loss (Towns \& Daugherty 1994; Hitchmough et al. 2016a). As lizards coevolved with avian and reptilian predators, they developed traits that made them more susceptible to predation by olfactory-sensing mammalian predators e.g. crypsis, distress calls, or the freeze response (Hare et al. 2016). Native lizards also display K-selected life history traits, such as slow reproduction and increased longevity, which reduces their ability to bounce back after population-reducing events (Cree \& Hare 2016). Additionally, lizard assemblages are highly structured, with many species exhibiting high site fidelity and therefore low dispersal among meta-populations, further exacerbating the risk of population decline as a result of mammalian predation (Hare et al. 2016). Currently $87 \%$ of New Zealand's lizard fauna are considered 'At Risk' or 'Threatened' under the New Zealand Threat Classification System (Hitchmough et al. 2015). As a result, the survival of many lizard species is dependent on conservation actions such as predator control, eradication, or range extension through translocation, but lizard conservation on the mainland, where more complex ecosystems and 
predator-prey dynamics exist, has had variable success (Towns \& Daugherty 1994; Hare et al. 2016; Nelson et al. 2016; Romijn \& Hartley 2016). The effect of avian species on lizard populations after mammal eradication, or translocation to mammal-free areas, needs investigation (Hitchmough et al. 2016a). To fully understand the threats that lizard species face, even after conservation efforts, a more in-depth view of lizard predation by birds is needed. This is particularly important as even opportunistic feeding by predators can have significant effects on small or vulnerable lizard populations (Reardon et al. 2012; Baling et al. 2013, 2016).

\subsection{Quantifying predation using lizard replicas}

Predation is difficult to study in the wild as it is a fleeting and secretive behaviour. As a result, predation studies largely rely on indirect methods of assessment (Steffen 2009). Predation can be inferred using methods such as direct observation (Piorno et al. 2016), camera capture (Busbridge \& Stewart 2018), diet analysis from necropsy or faecal matter (van Winkel 2008), isotope analysis (Meckstroth et al. 2007), prey survivorship (Schneyer 2001), or caudal autotomy (Hare \& Miller 2010; Knox 2014). However, each method comes with its own merits and challenges (reviewed in Birkhofer et al. 2017). Within New Zealand, the inference of predation has largely involved one-off direct observations or occasional diet analyses (Table 1.1). While diet analyses provide information regarding the species taken by individual predators, sample sizes are often small due to the opportunistic collection of faecal matter or carcasses. Similarly, direct observations of predation are uncommon and are therefore hard to translate into impacts on populations. In order to understand threats experienced by lizard populations in New Zealand we need to understand the predation pressure entire bird assemblages exert on lizard populations across sites.

Internationally, the use of prey replicas has provided invaluable information regarding the mechanistic action of predation on lizard species (e.g. Castilla et al. 1999; Diego-Rasilla 2003a; Shepard 2007). Replica use is becoming prominent within predator-prey interaction studies due to its welfare positive methodology, relatively low production cost, and increased flexibility to control and manipulate experimental variables (Bateman et al. 2017). Replicas are designed to mimic prey species and are often made of clay to allow predator attacks to be recorded and later identified (Bateman et al. 2017). Replicas have been used to quantify avian predation pressure experienced by lizard populations internationally, and how pressures may vary as a result of differences in prey morphology and distribution (Steffen 2009; Sato et al. 
2014; Purger et al. 2017; Hansen et al. 2019). For example, Purger et al. (2017) investigated whether the predation of wall lizards (Podarcis muralis) was dependent on prey density by placing replicas at differing distances along transects. Lizard replicas have successfully been used in New Zealand to identify differences in attack frequency across colour morphs of the shore skink, O. smithi (Baling 2017). While the research did not focus on identifying predation pressure exerted by birds on the population itself, or identifying the relative pressures exerted by each bird species, it shows that the use of lizard replicas may be a viable option for quantifying lizard predation within New Zealand (Baling 2017).

\subsection{Key questions and thesis outline}

My thesis examines the use of lizard-mimicking replicas to index the predatory effect of birds on lizard populations within New Zealand. I investigate whether 3D printed lizard replicas can be used as a standardised method for assessing predation on lizards by birds and examine factors that may influence predation on lizards across environments. In my thesis I aim to:

- determine if clay models are recognised by birds as prey items;

- determine which species are preying on lizard replicas, and to what extent;

- and evaluate how vegetation and weather factors influence predation.

This thesis is written as two stand-alone manuscripts formatted for publication in peerreviewed journals. In Chapter 2, I assess the use of 3D-printed lizard replicas as a tool to quantify the predation pressure that lizard populations experience from avian species. Having a standardised method to quantify predation across sites allows conservation managers to make informed decisions when moving or managing vulnerable lizard populations. In Chapter 3, I identify the bird species preying on lizard replicas and investigate how vegetation and weather variables affect predation rates. By providing context for predation risk for lizard species, I address the lack of knowledge surrounding limits to lizard population success in mammal-free environments. In Chapter 4, I provide a general discussion regarding influences on predation of lizards by birds, including the assemblage of bird predators, presence of specific bird predators and their foraging behaviour, foraging seasonality, and interactions with habitat. I also provide a short discussion on how threats to lizard populations may be reduced. 


\section{Chapter 2: Assessing the use of lizard-mimicking replicas to quantify avian predation on lizards in New Zealand}

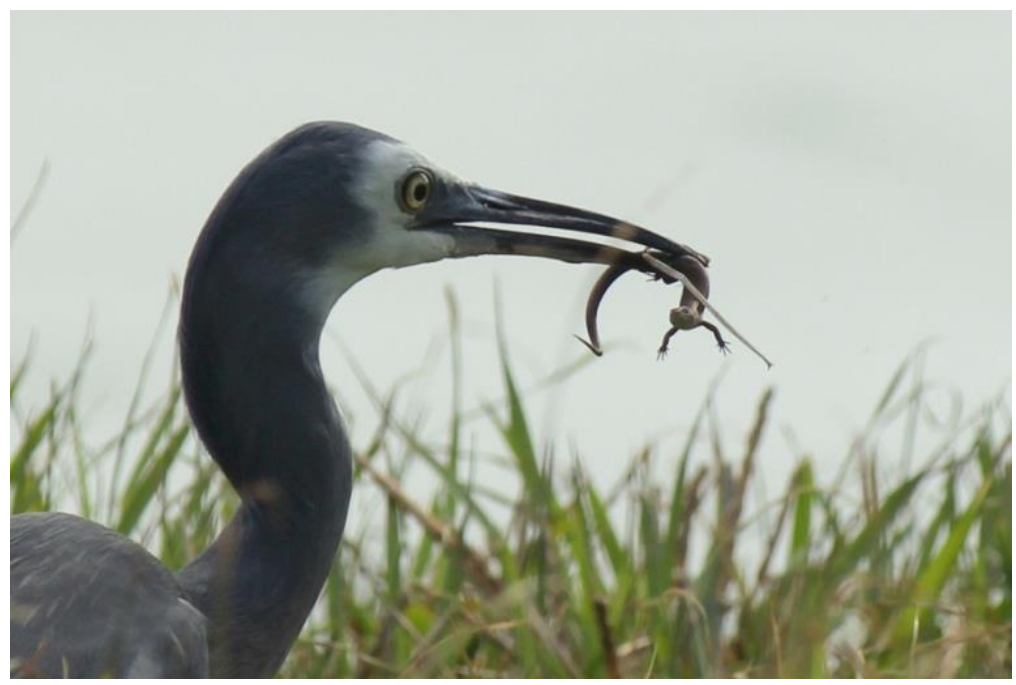

A white-faced heron (Egretta novaehollandiae) playing with an unidentified skink in Muriwai, Auckland.

Photographed and approved for use by Anna Arrol (June 2015).

\subsection{Introduction}

\subsubsection{Predator-prey interactions in New Zealand}

Within New Zealand, lizards are frequently preyed upon by a wide array of mammals, birds, and reptiles (Hare et al. 2016). The introduction of mammals to New Zealand contributed to the rapid decline and fragmentation of lizard populations around the country (Towns \& Daugherty 1994). As a result, the impacts of mammalian predation on lizard species have been widely studied. This has been to the detriment of our knowledge surrounding natural predators. Before the introduction of mammalian predators, birds and reptiles were considered the key predators within New Zealand ecosystems (Daugherty et al. 1993; Towns \& Daugherty 1994). However, currently we know little about these predator-prey interactions within New Zealand (van Winkel \& Ji 2012). 
Globally, birds are recognised as key predators of lizards (Martin \& Lopez 1996; Padilla et al. 2007). Birds are a highly mobile and ubiquitous group of animals that have the ability to forage over wide areas (Cummings et al. 1997; Serong \& Lill 2016). They are efficient predators, utilising a 'search image' of prey, which allows them to detect even cryptic species within an environment (Langley 1996; Veselý et al. 2013). Lizards, as ectotherms, are particularly vulnerable to predation as necessary thermoregulatory behaviours can increase their exposure to predators (Coombs 2016).

\subsubsection{Quantifying predation using clay models}

Predation is an often fleeting and secretive event, making it difficult to detect in situ. As a result, predation is often measured using indirect methods such as direct observation (Piorno et al. 2016), camera capture (Busbridge \& Stewart 2018), diet analysis from necropsy or faecal matter (van Winkel 2008), isotope analysis (Meckstroth et al. 2007), prey survivorship (Schneyer 2001), or caudal autotomy (Hare \& Miller 2010; Knox 2014). Each method has associated merits and downfalls, such as the limited range of data provided by opportunistic diet analyses, or costs associated with isotope analyses (reviewed in Birkhofer et al. 2017).

Clay model studies are a relatively modern method of monitoring predation and their use has gained global popularity (reviewed in Bateman et al. 2017). Prey-mimicking replicas may be limiting for studies investigating predation by olfactory-sensing predators, such as mammals, but they are particularly successful for studies investigating the effects of visual predators who use search images to detect prey (Bateman et al. 2017). Clay models have successfully been used to investigate predation on a variety of animals, including caterpillars (Muchula et al. 2019), arachnids (Mason et al. 2018), bird eggs (Rangen et al. 2000), snakes (Coombs 2016), and lizards (Hansen et al. 2019). Models can be constructed directly from clay or plasticine to mimic prey, or are constructed by coating a prey-mimicking replica in clay or plasticine. Both methods provide a standardised model that can be deployed across multiple sites that allows predatory, or intra-species, interactions to be identified and recorded. The use of replicas has allowed researchers to control variables they would otherwise be unable to manipulate, such as an individual's position in time or space (e.g. differences across elevation or latitude [Muchula et al. 2019], or season [Mason et al. 2018]), or the morphology of prey species (e.g. colour [Bateman et al. 2014], or shape [Shepard 2007]). 


\subsubsection{Importance of quantifying predation on lizards}

New Zealand is home to a highly diverse lizard fauna, containing over 100 species within the gecko (Diplodactylidae) and skink (Scincidae) families (Hitchmough et al. 2015; van Winkel et al. 2018). Only half of these species are formally described, with new cryptic species being discovered with taxonomic reform (Nielsen et al. 2011; Hitchmough et al. 2015). Currently, $87 \%$ of lizard species are considered 'At Risk' or 'Threatened' under the New Zealand Threat Classification System (Hitchmough et al. 2015).

Anecdotal evidence gathered from photographs, direct observations, food pellets, and stomach analyses shows that many birds within New Zealand consume lizards (Table 1.1). Currently, 31 introduced and native avian species have been noted as predators of New Zealand lizards (Table 1.1). With the majority of these accounts remaining anecdotal, no direct index of predation formally exists (van Winkel \& Ji 2012). The impact of avian predation on New Zealand's lizard fauna is largely under researched, with only three studies attempting to improve knowledge in this field. Baling (2017) investigated avian attack rates on the shore skink, $O$. smithi, using lizard-mimicking replicas to identify the predation risk experienced by different colour morphs on differing backgrounds. The other two studies focused on speciesspecific interactions. van Winkel (2008) ran a feeding trial with a captive morepork (Ninox novaeseelandiae novaeseelandiae) and pūkeko (Porphyrio melanotus melanotus) finding that they will consume skinks but that lizard remains were unable to be identified within regurgitate or faeces. However, $88 \%$ of pellets collected from New Zealand kingfishers (Todiramphus sanctus vagans) on Tiritiri Matangi Island contained lizard remains (van Winkel 2008). The last study used exclusion nets to reduce the risk of avian predation on a translocated population of jewelled geckos (Naultinus gemmeus), but did not directly investigate predation rates experienced by this population (Schneyer 2001). While these three studies have contributed to our knowledge of avian predation within New Zealand, they have not attempted to provide a measure for predation pressure experienced by lizard communities. There is still a need for a methodology to assess avian predation on New Zealand's lizard fauna, so management strategies can remain informed when making decisions regarding population and species management, especially in places where bird populations are thriving such as mainland sanctuaries. 
I aimed to test the efficacy of using lizard-mimicking replicas as a tool for assessing avian predation upon lizards in New Zealand. I compared the frequency of bird interactions upon lizard-mimicking replicas and non-prey control items and recorded the characteristics of these attacks. Specifically, I addressed the following questions:

- Do bird interactions occur more frequently on lizard replicas than on novel items?

- Do different parts of the lizard models show signs of pecks more frequently than others?

- At what point during the exposure period are birds finding and interacting with models?

- Does attack frequency vary by beak size (i.e. differing sizes of the avian predator)?

\subsection{Methodology}

\subsubsection{Study species}

The greater Wellington region is home to fourteen species of lizard, only four of which are classified as nationally non-threatened: Oligosoma aeneum, O. polychroma, Woodworthia maculata, W. "Marlborough mini” (Hitchmough et al. 2015; van Winkel et al. 2018; Bell 2019; Crisp 2020). Nine species within the region are considered "At Risk" with declining (Mokopirirakau “southern North Island”, Naultinus punctatus, O. zelandicum, O. ornatum, O. infrapunctatum), relict (Hoplodactylus duvaucelii, O. kokowai, and W. chrysosiretica) or recovering (O. macgregori) populations (Hitchmough et al. 2015; van Winkel et al. 2018; Bell 2019). Three of these species only survive within the region on offshore islands (van Winkel et al. 2018; Bell 2019). Wellington is home to one of the six nationally endangered species, $O$. whitakeri, which has been restricted, within the region, to a single and likely extinct population at Pukerua Bay on the Kapiti Coast (Miskelly 1997; van Winkel et al. 2018).

\subsubsection{Research locations}

I conducted this research across four locations within the Wellington region, New Zealand: Mana Island, Matiu/Somes Island, the southern Miramar Peninsula, and Zealandia Ecosanctuary (Figure 2.1). I chose locations to cover a wide range of communities representing a variety of bird species in areas where there are known lizard populations. Further detail of habitat sites and maps of each location are provided in Chapter 3. 


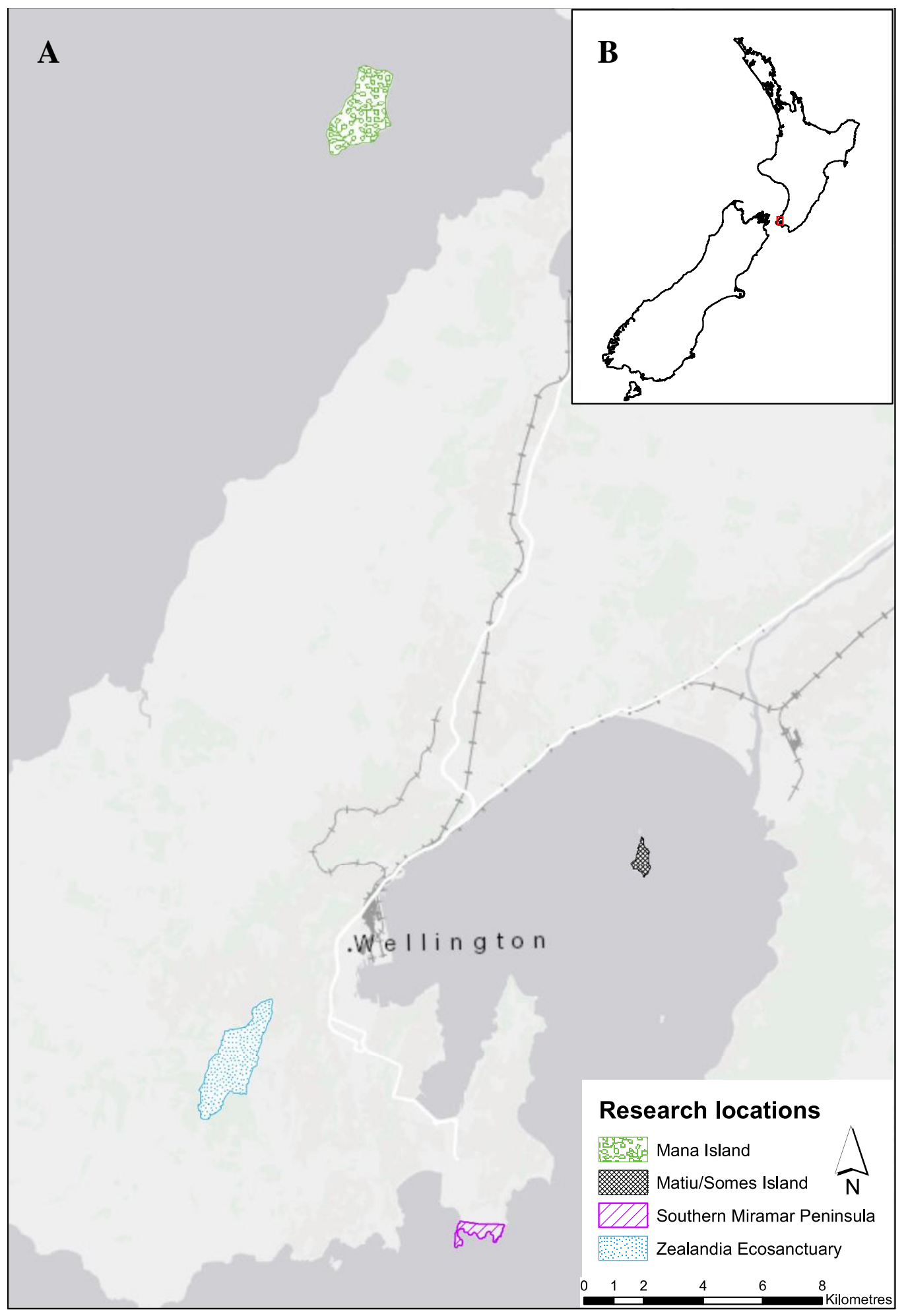

Figure 2.1: (A) Map of the Wellington region, New Zealand, highlighting the four research locations used within this study. Land area is represented by light grey and green, and oceans by dark grey. (B) Locator map of New Zealand indicating the Wellington region using a red rectangle. Created using Esri ${ }^{\circledR}$ ArcMap $^{\mathrm{TM}}$ v.10.6.1. Base map sourced from LINZ Data Service. 
The northern-most site, Mana Island $\left(41^{\circ} 05^{\prime} 24.4^{\prime \prime} \mathrm{S} 174^{\circ} 46^{\prime} 52.3^{\prime \prime} \mathrm{E}\right)$, sits $2.5 \mathrm{~km}$ off the southwest coast of the North Island (Figure 2.1). The island is a 217-ha predator-free scientific reserve managed by the New Zealand Department of Conservation (DOC). Historically used as pastureland, efforts to restore the island began with the eradication of mice in 1989 (Newman 1994). Since then, significant conservation efforts have restored the island to a mixture of regenerated and restored forest, restored wetlands, and large rocky coastal areas (Miskelly 1999, 2010). The island is currently home to six resident lizard species (O. aeneum, O. polychroma, O. macgregori, O. zelandicum W. chrysosiretica, and W. maculata) and five translocated species (H. duvaucelii, M. "southern North Island”, N. punctatus, O. kokowai, O. infrapunctatum) (Miskelly 1999, 2010). I chose three areas on the island as research sites for this study, to cover a variety of habitats and bird species: Wētā Valley, Shingle Point, and a shingle beach on the southeast coast. A detailed map of Mana Island sites is provided in Chapter 3 as Figure 3.1.

Matiu/Somes Island is located $8 \mathrm{~km}$ from central Wellington and sits in the middle of Wellington Harbour $\left(41^{\circ} 15^{\prime} 29.5^{\prime \prime} \mathrm{S} 174^{\circ} 51^{\prime} 57.2^{\prime \prime} \mathrm{E}\right)$. The island is a 29.4-ha historic and scientific reserve owned by Taranaki Whānui ki te Upoko o te Ika and managed by DOC. The landscape consists of a mixture of pioneer and coastal forest, cliff communities, grazing pasture, and wetlands (Department of Conservation 2000). Restoration of the island began as a joint venture by the Ministry of Agriculture and Fisheries, DOC, and the Lower Hutt branch of Royal Forest and Bird New Zealand (Hector 2011). Conservation efforts on the island include the eradication of rats in 1989 , rigorous native planting programmes that are still in effect today, and multiple translocations of birds, invertebrates, and lizards (Hector 2011). Matiu/Somes is now home to three species of translocated lizard ( $M$. "southern North Island", $N$. punctatus, and $O$. ornatum); in addition to the four existing resident lizard species $(O$. aeneum, O. kokowai, O. polychroma, and W. maculata) (Department of Conservation 2000; Hector 2011). The three areas on the island I chose as research sites for this study were the northern wharf, southern walkway, and bunker paddock. For a detailed map of the sites used, refer to Figure 3.2 in Chapter 3.

Miramar Peninsula ( $\left.41^{\circ} 17^{\prime} 26.2^{\prime \prime S} 174^{\circ} 49^{\prime} 32.2^{\prime \prime E}\right)$ is an 800-ha area east of central Wellington and comprises a mix of residential and industrial areas, and green spaces (reserves and parks). In Wellington City Council's latest Biodiversity Strategy and Action Plan a plan was put in place to turn the peninsula into New Zealand's first predator-free urban area (Wellington City 
Council 2015). Multi-species trapping carried out by both the regional and city councils and community groups has resulted in the possible eradication of possums, though rodents and mustelids are still present in suppressed numbers. (Wellington City Council 2015; Predator Free Wellington 2019). At least three species of lizard have been recognised as residents of the peninsula: O. aeneum, O. polychroma, and W. maculata (Bell 2019). I chose three study sites located on the southern tip of the peninsula: Moa Point, Rangitatau Reserve, and Wahine Memorial Park. These sites are detailed further in Chapter 3 Figure 3.3.

Zealandia Ecosanctuary is a 225-ha "mainland island" located southwest of Wellington central in the suburb of Karori (41 $\left.17^{\prime} 26.9^{\prime \prime S} 174^{\circ} 45^{\prime} 12.2^{\prime \prime E}\right)$. A mammalian predator exclusion fence surrounds the sanctuary providing a safeguard against all mammals except mice (Mus musculus), which are monitored and controlled. Zealandia was the first mainland ecosanctuary to be constructed in New Zealand, and now safeguards a flourishing community of native birds (Miskelly 2018). The ecosanctuary is home to eight species of lizard ( $M$. "southern North Island", N. punctatus, O. aeneum, O. kokowai, O. ornatum, O. polychroma, O. zelandicum, and W. maculata) (Melzer \& Bell 2014; Lynch 2019). I chose three study sites located within the sanctuary: along the eastern perimeter fence, within the mouse-proof tuatara research area, and along the slope where northern spotted skinks (O. kokowai) were released. A map of sites is provided in Chapter 3 Figure 3.4.

\subsubsection{Replica construction}

To standardise clay model design, I created lizard replicas from a 3D scan of a shore skink $(O$. smithi) previously developed for use in research conducted by Baling (2017). This species is morphologically similar to species within the Wellington region. The scan file is available through Sketchfab under 'Shore skink' (direct link: https://skfb.ly/6J68u). Replicas were 3Dprinted (UP BOX+, 3D Printing Systems, www.3dprintingsystems.com) using acrylonitrile butadiene styrene plastic filament. Replicas were printed to have a snout-vent length (SVL) of $60 \mathrm{~mm}$ (snout to tail length $=130 \mathrm{~mm}$ ). I chose the size and shape representative of the two most commonly encountered species in Wellington: $O$. aeneum $(<76 \mathrm{~mm} \mathrm{SVL})$ and $O$. polychroma (<80 mm SVL) (Hitchmough et al. 2016b; van Winkel et al. 2018; Bell 2019). 
I coated each replica in a thin layer, $\sim 2-3 \mathrm{~mm}$, of non-toxic brown animation clay (Newplast Animation Clay 500 gm Brown, United Kingdom) (Figure 2.2). Animation clay remains malleable and does not harden in warm, sunny conditions, allowing attacks on replicas to leave an imprint that can be subsequently recorded. Additionally, I avoided oven-bake brands due to the presence of a potentially toxic polymer-base with the potential to harm birds if consumed (Rößler et al. 2018). I left the ventral side of each replica bare to allow affixation to a large, flattened river stone ('beach flats - medium', The Goods Shed, Wellington; dimensions $~ 10$ $20 \mathrm{~mm}, \sim 45-75 \mathrm{~mm}$, and $\sim 50-100 \mathrm{~mm}$ ). I glued replicas to stones to provide a standardised background, and to reduce model removal by predators (e.g. $81 \%$ of models were lost in a study by Castilla et al. 1999).

With all clay model studies there is an assumption that the general shape and colour of preymimicking replicas will be recognised by visual-searching predators (Castilla et al. 1999; Shepard 2007). I used a novel item to determine whether predators were interacting with replicas simply because of the smell or appearance of the plasticine (Rößler et al. 2018). There is a lack of standardised design for control items in other studies (e.g. washers Mason et al. 2018; cubes McMillan \& Irschick 2010) which likely stems from the lack of controls used within clay model studies (reviewed in Bateman et al. 2017). I chose six-sided dice (dimensions $15 \times 15 \times 15 \mathrm{~mm}$ ) as the novel item due to their lack of resemblance to existing prey items across research locations (Paluh et al. 2015). I prepared dice using the same methods as replicas (Figure 2.2).
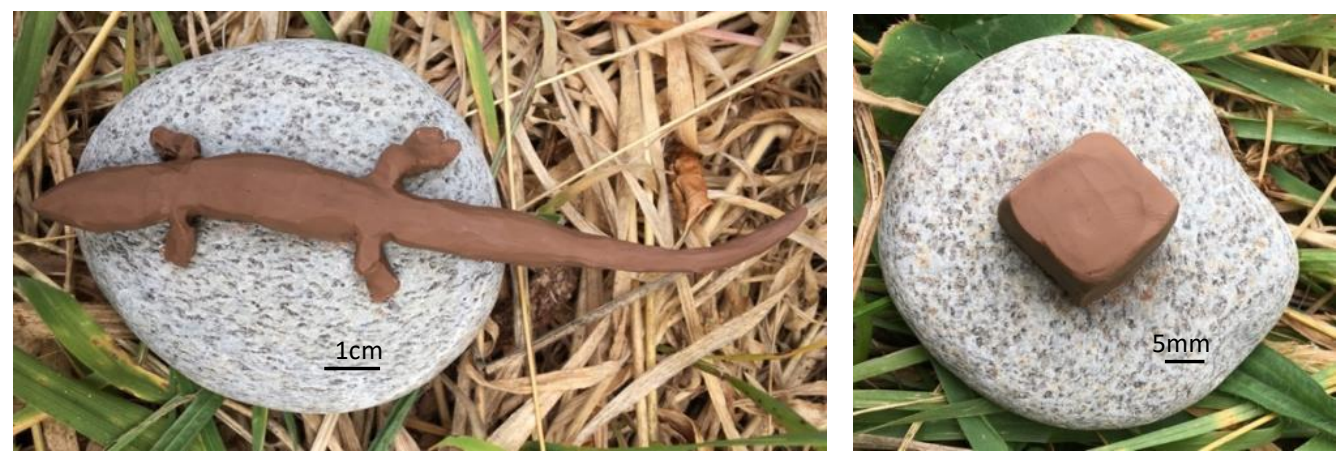

Figure 2.2: Example of the clay models (lizard replica and novel item) used within this study. Both clay models are glued to flat river stones to reduce model loss and provide a standardised background. 


\subsubsection{Replica deployment and monitoring}

\subsubsection{Clay model placement}

Between January and May 2019 (summer through to autumn), I deployed a total of 330 lizard replicas and 165 novel items across four research locations (Table 2.1). Three sites were chosen at each of the four research locations, making a total of 12 research sites. Sites within locations were chosen to capture the maximum possible diversity of bird communities present, whilst also providing varying habitat for clay model deployment.

During each deployment, I placed ten lizard replicas and five novel items in each of the three study sites, totalling 45 clay models at each research location. I placed clay models in a randomised fashion in areas I judged to be good lizard basking sites. Basking sites were largely in sunny or open habitat, and/or in areas where lizards were seen basking (e.g. on the side of tracks). In publicly accessible landscapes, such as Zealandia and Matiu/Somes, I chose sites in edge habitat to reduce the likelihood of disturbance by the public.

\subsubsection{Monitoring predation}

Clay models were exposed continuously across 24-hour periods, for a maximum of four days at each location (Table 2.1). Due to limitations imposed by arrival and departure times on islands, some sites were started on the day of arrival and others did not start until the following day, but all ran for four consecutive days (exceptions stated in Table 2.1). 
Table 2.1 - Dates that research was carried out at each of the four Wellington locations during 2019. Replicate refers to a repeated experiment at each location. Each replicate had four days of lizard replica exposure to birds. Research dates refers to the initial date of deployment of clay models to the date they were collected.

\begin{tabular}{|l|l|l|}
\hline Location & Replicate & Research dates \\
\hline \multirow{4}{*}{ Mana Island* } & 1 & $23^{\text {rd }}-27^{\text {th }}$ January \\
\cline { 2 - 3 } & 2 & $27^{\text {th }}$ January $-1^{\text {st }}$ February \\
\cline { 2 - 3 } & 3 & $6^{\text {th }}-11^{\text {th }}$ February \\
\cline { 2 - 3 } Matiu/Somes Island & 4 & $10^{\text {th }}-16^{\text {th }}$ February \\
\hline \multirow{2}{*}{ Miramar } & 1 & $28^{\text {th }}$ February $-5^{\text {th }}$ March \\
\cline { 2 - 3 } & 2 & $15^{\text {th }}-20^{\text {th }}$ March \\
\hline \multirow{3}{*}{ Zealandia Ecosanctuary } & 1 & $20^{\text {th }}-24^{\text {th }}$ February \\
\cline { 2 - 3 } & $2^{\wedge}$ & $9^{\text {th }}-15^{\text {th }}$ April \\
\cline { 2 - 3 } & $1^{\wedge}$ & $18^{\text {th }}-21^{\text {st }}$ January \\
\cline { 2 - 3 } & 2 & $23^{\text {rd }}-27^{\text {th }}$ April \\
\hline
\end{tabular}

* Access to Mana Island was limited to 10-day periods, so I conducted two consecutive replicates during these expeditions. Deployment across sites was staggered and in some cases the beginning and end of experiments overlapped across sites.

$\wedge$ Replicates that had three days of lizard replica exposure.

Once deployed, I checked the clay models once daily for signs of predation, between the hours of 0800 and 1700 NZST. During each check I recorded whether models were unmarked, pecked, moved, or missing. I identified bird predation by the presence of ' $U$ ' or ' $V$ ' shaped beak imprints within the clay (e.g. Figure 2.4; Low et al. 2014). I assigned peck events conservatively to avoid uncertainty surrounding the number of visits to models by predators throughout the period of exposure. When a model was identified as pecked by any avian predator during a check, I assigned it as a single day of predation, rather than assigning individual events. Daily checks were therefore classified as days of predation and days of nonpredation. I did not classify missing replicas as pecked due to the uncertainty surrounding their removal from site unless the model was recovered and showed clear avian attack marks. Any peck marks recorded were rounded up to the closest 24-hour period. The size of peck mark and location of attack on the skink replica were recorded (Figure 2.3). 


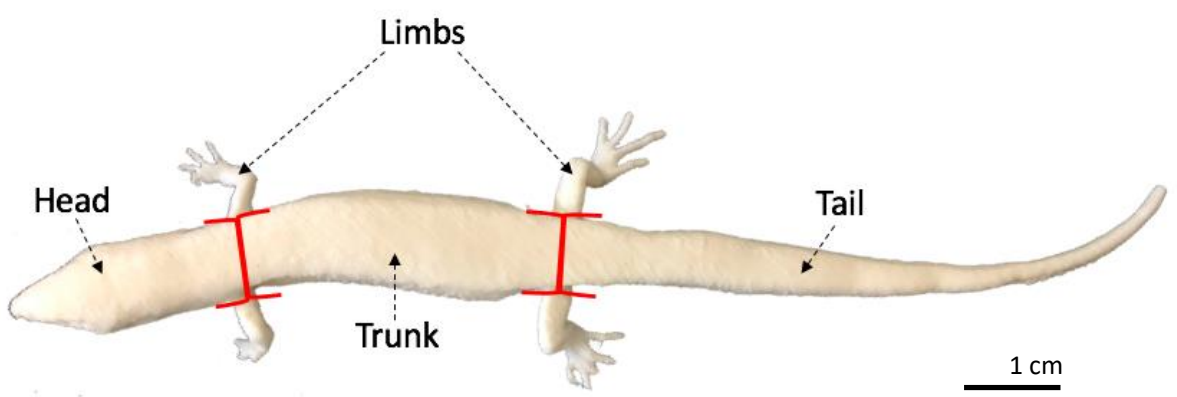

Figure 2.3: Map of possible peck locations on lizard replicas. Lizard replicas were split into four body regions and pecks directed at these regions were recorded. Red notations indicate the separation of body regions.

Within clay model studies, there is an assumption that beak width and beak length are largely proportional to size of predator (e.g. Low et al. 2014; Mason et al. 2018). I determined whether peck marks were from 'small' (width of $\leq 1.5 \mathrm{~mm}$ ), 'medium' $(1.5-2.5 \mathrm{~mm})$, or 'large' birds ( $\geq 2.5 \mathrm{~mm}$ ) (Figure 2.4). During daily checks, a beak size was assigned to each predation event for each lizard replica and novel item. When multiple peck marks were identified on clay models, I classified those of the same beak size as one attack and different beak sizes as separate attacks. An additional category of 'stripped' was introduced for novel items, as during the experiment some models were found completely devoid of modelling clay. I identified other interaction marks from other non-focal taxa, such as those from rodents or arthropods but did not include them within the analysis. I reapplied clay on attacked models during daily checks to reset them for the subsequent 24-hour exposure period. Additionally, I replaced clay on replicas as required to avoid discolouration or cracking as a result of sun exposure and rainfall (Lemessa et al. 2015).
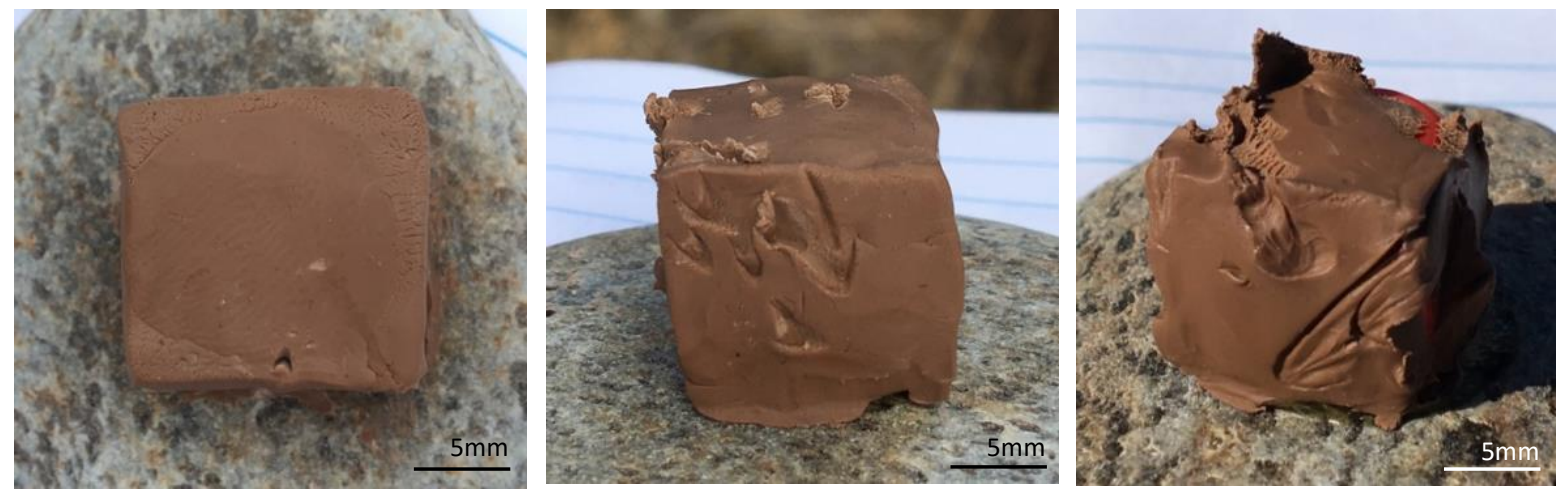

Figure 2.4: Examples of the three peck sizes assigned to attacks during daily checks. From left to right: small $(\leq 1.5 \mathrm{~mm})$, medium $(1.5-2.5 \mathrm{~mm})$, and large $(\geq 2.5 \mathrm{~mm})$. 


\subsubsection{Statistical analysis}

Data were pooled for all research locations in order to provide a large sample size. All analyses were done in R v.3.6.1 (R Core Team, Vienna, Austria). All graphs were created using the ggplot2-package in R (Wickham 2016).

I used the glmer function in the lme4-package to run a generalised linear mixed-effects model (GLMM) to determine whether overall predation ('Attacked'/ 'Not attacked' during entire exposure) on clay models differed across model types. (Bates et al. 2015). I included the binary predation data as the response variable and model type ("Replica"/"Novel item") as the fixed factor. To account for pooled data, site (12 levels) was included within research location (4 levels) as a nested random factor.

I ran an additional GLMM to determine whether daily predation rates on clay models were influenced by model type. Daily predation on clay models ('Attacked'/ 'Not attacked') was included as the response variable, model type ("Replica"/"Novel item") as the fixed factor. To account for pooled data, site (12 levels) was included within research location (4 levels) as a nested random factor. Date and clay model identity (465 levels) were also included as a random factors to account for the multiple checks conducted across exposure days for each replica.

\subsection{Results}

\subsubsection{Clay model exposure}

The number of days clay models were exposed for varied according to circumstances at each location (Table 2.2). The majority of lizard replicas and novel items were exposed to predators for the maximum period of four days (81.8\% and $80.6 \%$ respectively; Table 2.2). Some clay models were exposed for only two $(3.2 \%)$ or three days $(15.4 \%)$ due to change in weather, or because there were limited replacements available. All novel items at Mana Island were deployed for four days. All lizard replicas on Matiu/Somes Island were exposed for four days; however, novel items at some sites on the island had a reduced duration of exposure (less than four days) as they were unable to be replaced when they went missing. Novel items were also exposed for a reduced amount of time at sites at southern Miramar Peninsula and Zealandia Ecosanctuary. 
Fifteen models had a reduced exposure period of two days at the Miramar research location due to a temporary sewage discharge making the Moa Point site inaccessible for 48 hours. These clay models were included in the analysis as they were exposed and monitored for two days before the site became inaccessible.

Table 2.2 - Number of exposure days across lizard replicas and novel items by research location. Exposure days are defined as the number of sequential 24-hour periods for which clay models were exposed to predators.

\begin{tabular}{|c|c|c|c|c|c|c|c|c|}
\hline & \multicolumn{4}{|c|}{ Lizard replica } & \multicolumn{4}{|c|}{ Novel item } \\
\hline & \multicolumn{3}{|c|}{$\begin{array}{l}\text { Number of } \\
\text { exposure days }\end{array}$} & \multirow[t]{2}{*}{$\begin{array}{l}\text { Total } \\
\text { replicas }\end{array}$} & \multicolumn{3}{|c|}{$\begin{array}{l}\text { Number of } \\
\text { exposure days }\end{array}$} & \multirow[t]{2}{*}{$\begin{array}{l}\text { Total } \\
\text { items }\end{array}$} \\
\hline & 2 & 3 & 4 & & 2 & 3 & 4 & \\
\hline \multicolumn{9}{|l|}{ Research locations } \\
\hline Mana Island & N/A & N/A & 120 & 120 & N/A & N/A & 60 & 60 \\
\hline Matiu/Somes Island & N/A & N/A & 60 & 60 & 1 & 1 & 28 & 30 \\
\hline Southern Miramar & 10 & 20 & 30 & 60 & 5 & 10 & 15 & 30 \\
\hline Zealandia Ecosanctuary & N/A & 30 & 60 & 90 & N/A & 15 & 30 & 45 \\
\hline Total & 10 & 50 & 270 & 330 & 6 & 26 & 133 & 165 \\
\hline
\end{tabular}

\subsubsection{Predation on lizard replicas and novel items}

In total, 330 lizard replicas were deployed throughout the Wellington region. Nearly one-third (32.4\%) were attacked by birds at least once during this time (Figure 2.5). A total of 144 predation days were recorded across 107 lizard replicas. When looking at pooled data from all sites, the majority of attacked replicas (72\%; 77 out of 107) experienced only one day of predation. Data also showed it was less common for replicas to be attacked across two or three days, with $21.5 \%$ and $6.5 \%$ replicas attacked, respectively. No lizard replicas were attacked on all four days (the maximum time of exposure).

During daily checks, four lizard replicas were recorded as missing - two of which were able to be replaced. Those unable to be replaced were recorded as having a reduced exposure time (Table 2.2). Four replicas were identified as being noticeably moved: two of which were undoubtedly moved with human assistance; the other two were moved $\sim 0.5 \mathrm{~m}$ and were likely moved by birds as they were located on the isolated Mana Island which experiences very few off-track visitors. 
Fifty-six (33.9\%) of the 165 novel items deployed were attacked by birds at least once during their time of exposure (Figure 2.5). A total of 92 predation days were recorded across 56 novel items. The majority (28 of 56) of novel items only experienced one day of predation. Only $39.3 \%$ were attacked on two days, $7.1 \%$ attacked on three days, and 3.6\% attacked on all four days. When adjusted for the number of days models were exposed, through the removal of clay replicas exposed for less than four days, there was no significant change in the spread of data (Figure 2.5).

Six novel items were recorded as missing during daily checks, three of which were able to be replaced. Two are likely to have been moved by birds as they were located on Mana Island. The other four could have been moved by humans, as Matiu/Somes Island is inundated with visitors daily. Twelve novel items were recorded as being noticeably moved from the original place of deployment, eleven of these events involved predation attempts on the clay models. Models were moved an average distance of $4.97 \mathrm{~m}(\mathrm{SEM} \pm 1.64 \mathrm{~m}$, range $=0.2-15 \mathrm{~m})$, calculated from measurements taken in the field of eleven of the twelve predated models.
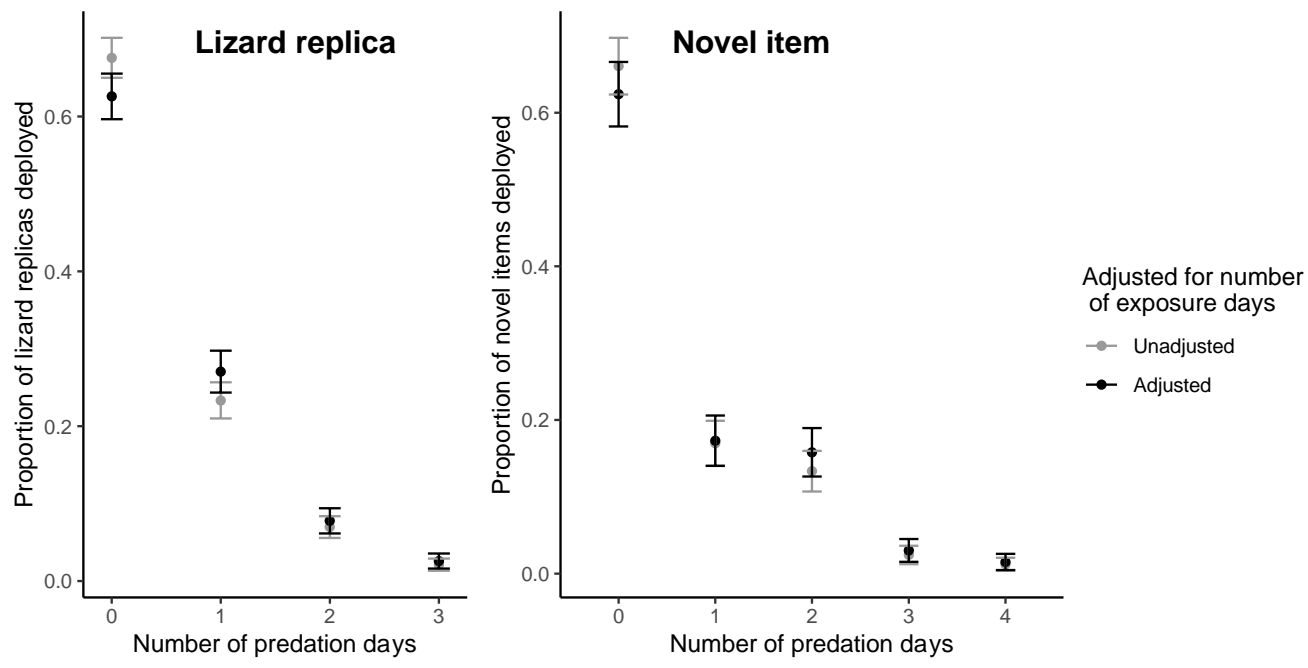

Figure 2.5: The number of predation days recorded for individual clays models. Adjusted values show only the proportion of lizard replicas $(n=270)$ and novel items $(n=133)$ that were exposed for the maximum length of time (four days). Unadjusted values show the proportion of lizard replicas $(n=330)$ and novel items $(n=165)$ for all models deployed. Error bars represent the standard error of proportion. 
There was no difference in the overall proportion of lizard replicas attacked compared with novel items. The generalised linear mixed-effects model found no difference $(p>0.05)$ between type of model (lizard replica or novel item) and whether models were attacked by birds $(\mathrm{GLMM}$, estimate $=0.07 \pm 0.227, \mathrm{z}=0.308, p=0.758)$. When this was broken down to look at daily predation, results suggest novel items are preyed upon more frequently than lizard replicas with the $\mathrm{p}$-value approaching significance $(\mathrm{GLMM}$, estimate $=0.323 \pm 0.168, \mathrm{z}=$ $1.921, p=0.055)$.

\subsubsection{Day until first peck event}

Time until first attack was defined as the day on which the first peck was recorded on an individual clay model. The majority of models, whether lizard replica or novel item, experienced their first predation event on the first day of exposure with $15.5 \%$ and $17.6 \%$ of exposed clay models pecked, respectively (Figure 2.6). A significantly lower proportion of lizard replicas were found and pecked on the second (9\%) and third (7.9\%) days of exposure. By the fourth day, only $4.7 \%$ of exposed replicas were pecked by birds. Similarly, the proportion of novel items being found and pecked dropped greatly between the first day of
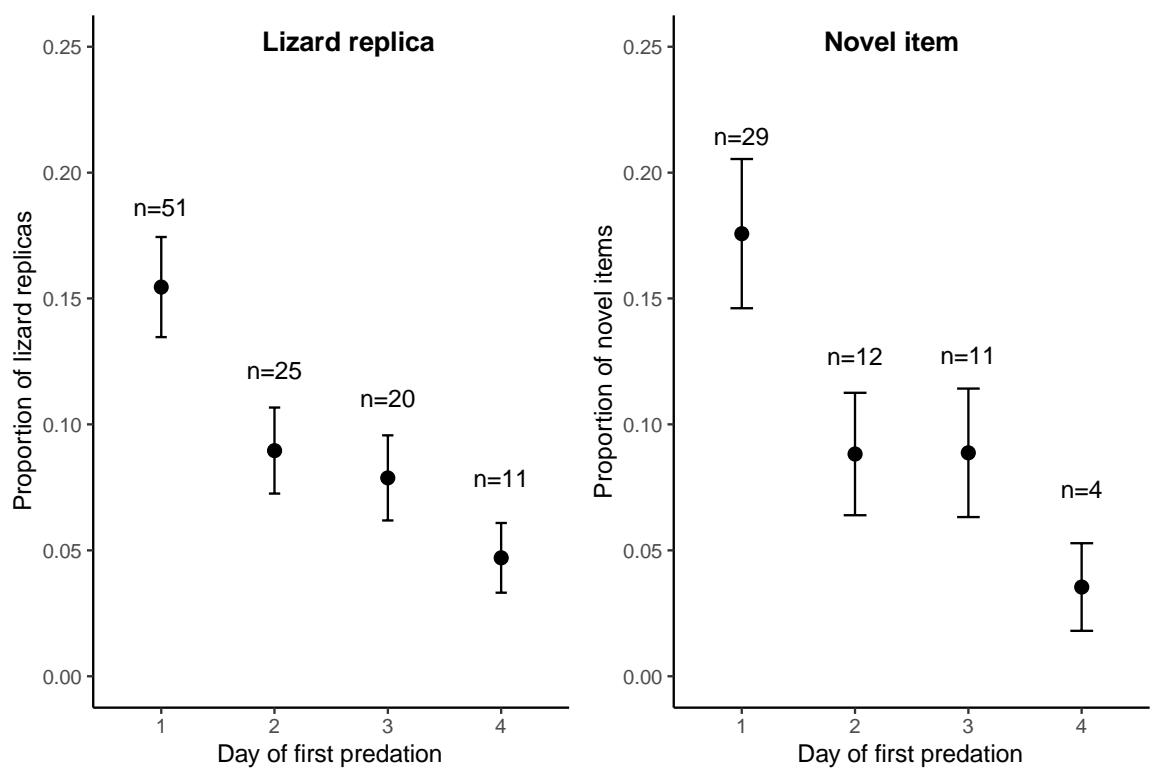

Figure 2.6: The number of days until first attack by birds for each model type. Proportion represents the number of models attacked of those exposed each day. Proportion was adjusted for the reduction of numbers by removing those attacked from the pool of those still available to be attacked. The graph is not adjusted for number of exposure days. Error bars represent the standard error of proportion. 
exposure (17.6\%), and the second (8.8\%) and third days (8.9\%) of exposure. By the fourth day of exposure only $3.5 \%$ of novels items were attacked by birds.

\subsubsection{Beak size of avian predators}

Attacks from two bird predators (i.e. two differing beak sizes) on a single lizard replica were recorded nine of the 144 replica exposure days on which predation occurred. Consequently, a total of 153 predation events were recorded. Attacks from two bird predators on a single novel item occurred twice within the 92 exposure days predation occurred, resulting in a total of 94 predation events.

'Stripped' items were classified as avian attacks, as the majority of cases (85.7\%) occurred at sites without mammals. A diverse array of arthropods were observed sitting on or interacting with replicas e.g. New Zealand grasshopper (Phaulacridium marginale), fierce ants (Tetramorium sp.), and unknown moth and Dipteran (Pers. obs.). Although ants were recorded consuming clay, these interactions showed obvious and easily attributable patterns (Pers. obs.).

The most common beak sizes recorded in attacks on lizard replicas were from large birds, accounting for $56.9 \%$ of predation events (Table 3.3). Thirty-four percent of predation events were attributed to medium-sized birds. There were noticeably fewer attacks on models by smaller birds, with only 14 events recorded (9.2\%). Medium and large peck marks were recorded at similar rates on novel items (Table 3.3). However, there were less frequent attacks by large birds on novel items (34.0\%), than lizard replicas (56.9\%). As novel items are smaller than replicas, full clay removal by predators is easier to achieve so this difference may be accounted for in the 14 novel items (14.9\%) that were found stripped of clay. The percentage of small pecks recorded on novel items $(12.8 \%)$ was comparable to that of lizard replicas (9.2\%), despite having twice as many replicas than novel items deployed. 
Table 3.3 - The number of predation events attributed to predators differing beak sizes recorded during daily checks. Values in parentheses represent the percentage of predation events attributed to each beak size.

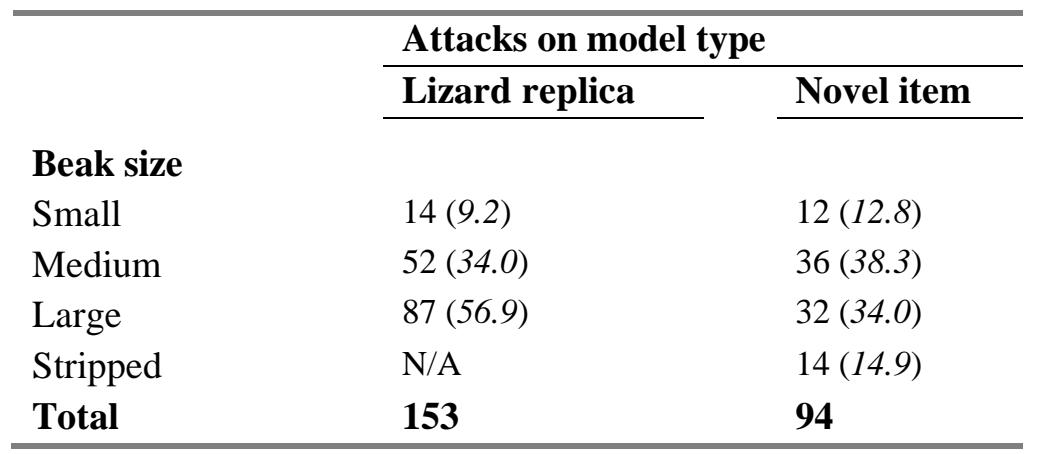

\subsubsection{Attack locations on lizard replicas}

Of the 153 predation events recorded for lizard replicas, $79(51.6 \%)$ predation events involved pecks on more than one body region. In $74(48.4 \%)$ predation events, only a single body region was pecked. A total of 274 attacks across differing body regions were recorded over the 144 predation days documented for lizard replicas.

Attack rates on anatomical regions are likely an artefact of surface area, with the expectation that random pecks are more likely to fall on larger regions of the body (Vervust et al. 2011). Therefore, I calculated the number of expected predation events on each body part and compared them to the number actually observed. I used a photograph of a lizard replica to measure the 2D dorsal surface area in ImageJ 1.52q (https://imagej.nih.gov/ij/; Schneider et al. 2012). I expect the morphometric measurements to remain unchanged, as the size ratio for each body region should not alter with scaling. Three measurements of each body region were taken by outlining each area and using the Analyze-function to produce a pixel area output. I used the averaged value in further calculations as there was little variation between the three measurements. Expected frequency was calculated by dividing body region by the summed total of all regions (i.e. the whole replica) to produce a proportion. Each proportion was then multiplied by the number of predation events observed, to create an expected attack value for each body part. A chi-square test of goodness-of-fit showed observed attack frequencies differed significantly from expected values $\left(\mathrm{X}^{2}=59.774, \mathrm{df}=3, p<0.001\right)$. 
Based on calculated values, I would expect the trunk to receive the highest number of attacks. However, when reviewing the number of predation events, the most frequent location of attacks was to the head (36.1\%), which was attacked twice as frequently as the trunk (19.7\%; Table 3.4). Attacks on the tail were at a similar frequency to attacks on the head (31.8\%). Attacks on the tail did not differ greatly between observed and expected values. Attacks on the extremities were less frequent, with limbs attacked one-third as often as the head (12.4\%).

Table 3.4 - The recorded location of attack for 274 predation events across the 107 pecked lizard replicas. The 'Observed (\%)' values represent the actual percentage of attacks recorded across body regions. The 'Expected (\%)' values represent the percentage of attacks expected if relative dorsal surface area influences the likelihood of pecks landing on body regions. Expected values were calculated using pixel ratios in ImageJ. The 'Probability of attack...' is calculated as the expected attack frequency divided by the observed attack. Values $<1$ represent a lower than expected attack probability. Values $>1$ represent a higher than expected attack probability.

\begin{tabular}{|c|c|c|c|}
\hline & Observed (\%) & Expected (\%) & $\begin{array}{l}\text { Probability of attack } \\
\text { relative to dorsal } \\
\text { surface area }\end{array}$ \\
\hline \multicolumn{4}{|c|}{ Body region } \\
\hline Head & 36.1 & 19.1 & 1.89 \\
\hline Tail & 31.8 & 31.7 & 1.0 \\
\hline Trunk & 19.7 & 34.5 & 0.57 \\
\hline Limbs & 12.4 & 14.7 & 0.84 \\
\hline
\end{tabular}

\subsection{Discussion}

Previous studies on avian predation within New Zealand have not attempted or have been unable to quantify predation rates experienced by lizard communities, and the few that did focused on impacts on individuals species (see Schneyer 2001; van Winkel 2008; Baling 2017). The results from this study indicate that clay models can be used as a tool to provide an index of avian predation pressure experienced by native lizard populations.

The main assumption of this study is that birds would recognise and attack lizard-mimicking replicas. Lizard replicas experienced a high proportion of attacks by birds, with beak marks recorded on $32 \%$ of the 330 replicas after four days of exposure. This was comparable to previous research conducted in New Zealand by Baling (2017) who found $40 \%$ of $O$. smithi replicas were attacked after six days of exposure. The rate of attack seen in this research was 
relatively high compared to other studies conducted overseas: $0.8-3.3 \%$ (Shepard 2007); 4\% after 2 days (Diego-Rasilla 2003b); 11\% on all-brown replicas (Bateman et al. 2014); 0-93\% (Castilla \& Labra 1998); and 67-92\% (Castilla et al. 1999). The high proportion of attacks experienced by replicas within this study indicates that the free-ranging bird communities across Wellington sites were successfully finding and interacting with replicas.

Birds tended to interact with lizard replicas on the first day of exposure. This was also the case for attacks on control items. Few clay replica studies have investigated when birds are finding and interacting with models. However, as some animals are shown to habituate themselves with novel objects within an environment before interacting with them it is important to understand when models are being attacked (Greenberg \& Mettke-Hofmann 2001). For example, Bateman et al. (2014) found that the majority of all-brown replicas of the Southeastern five-lined skink, Plestiodon inexpectatus, only received their first damage after five to seven days of exposure. Similarly, the majority of blue-tailed replicas of the same species received their first damage on the first two days of exposure, with the highest proportion of replicas receiving first damage on exposure day two (Bateman et al. 2014). In comparison, replicas in this study were found relatively quickly indicating birds were actively foraging around these study sites and that their interactions involving the lizard-mimicking replicas are not limited by neophobic behaviours. Additionally, during their time of exposure, the majority of models were only attacked once. While singular attacks could indicate birds were not actively foraging in the same locations across the four days of deployment, it could also indicate that birds recognise the unprofitability (i.e. no food reward) of replicas and therefore learn not to perform multiple attacks (Rößler et al. 2018). However, unprofitability does not affect the efficacy of the study as birds would likely only have one interaction with an individual which would determine whether the lizard is successfully preyed upon or escapes.

While birds were found to interact with lizard replicas, and clay models were a successful method of recording interactions, initial results suggest that birds may not have been recognising replicas as prey items. Birds were not found to preferentially attack lizard replicas over novel items. One explanation is that replicas did not fit the search image of avian predators. Replicas used within this study were a solid brown colour and showed no cryptic patterning. However, unpatterned replicas within a study by Baling (2017) experienced the same attack frequency as those created to mimic cryptic colouration. Other studies have shown visual predators, such as birds and reptiles, may use cues from the ultraviolet spectra to hunt 
prey (see Cuthill et al. 2000). However, replicas that do not exactly exhibit the same colouration and luminescence as prey have been shown to receive similar attack rates to replicas that have been modelled to directly mimic prey species (Marshall et al. 2015). Predators are known to allow a wide colour range within their search image so they can recognise prey under ambient lighting; which can differ throughout the day and location within an environment (Endler 1990). Additionally, prey species are not usually stationary in the wild and may not be well represented by static replicas. This is especially true in studies focusing on visual-searching predators, such as birds, that key into prey movement when hunting (Rößler et al. 2018). Therefore, it is doubtful that replica colouration or lack of patterning influenced the likelihood of predators recognising replicas as prey-items. Further research should be conducted to see if movement in lizard-mimicking models influences the probability of predation by visual searching predators, such as birds.

Another explanation for the lack of attack preference towards lizard replicas over novel items, is that birds perceived both the lizard replica and control as palatable items. Results can be skewed if novel items are perceived as another food source within the environment, artificially inflating the number of attacks on non-prey mimicking models (Paluh et al. 2015). The use of cuboid novel items in this study was an attempt to control for this error, as the use of geometrically shaped control items can reduce the number of unwanted attacks (i.e. those not from neophilic behaviour). McMillan \& Irschick (2010) found that their green cubes received no attacks when used as a null item for predation against green clay anoles (Anolis carolinensis). However, attack rates seen in studies largely depend on the foraging strategy employed by potential predators and where replicas may have been placed within an environment. For example, Pérez-Mellado et al. (2014) found ground foraging avian predators did not discriminate between a squared-stick control and lizard replicas, and therefore the birds were not exhibiting true predatory behaviour towards replicas. The foraging strategy of lizards themselves also influences predation risk, with sit-and-wait lizards less likely to encounter predators, unless the predator itself is an active forager (Huey \& Pianka 1981). The models used within this study were stationary and were placed at ground-level likely offering more opportunity for ground foraging predators to interact with and explore objects which could explain the similar attack rates experienced across model types. Therefore, it is likely that avian predators did not immediately distinguish lizard replicas as prey items when finding them in the field and consequently attack probability between these model types was the same. 
Although there was a non-significant difference in the probability of attack across model types birds interacted with lizard replicas as prey. The results indicate birds had an attack preference towards the head of replicas suggesting they were interacting with models in a predatory capacity, even if they did not immediately recognise the replicas as prey items. Attack frequency on the head was nearly twice what was expected based on dorsal surface area alone, which aligns with previous research showing avian predators have an innate tendency to attack the head and neck of prey (Smith 1973). Direct attacks on the head are thought to be an evolutionary advantage, providing an opportunity to efficiently stun or kill prey by targeting one of the most vulnerable and accessible body parts (Smith 1973; Langkilde et al. 2004; Vervust et al. 2011). This theory has been corroborated by a multitude of clay model studies, which have all reported seeing increased rates of avian attack on the head and neck of replicas mimicking lizards (Husak et al. 2006; Shepard 2007; Vervust et al. 2011; Bateman et al. 2014; Marshall et al. 2015) and snakes (Brodie III 1993; Webb \& Whiting 2005). In the wild, birds would only be given one opportunity to successfully maim or kill prey; so, by attacking the head, avian predators reduce the likelihood of prey escaping. Therefore, by attacking the head of replicas, birds within this study exhibited a realistic predatory response.

The second highest number of attacks were received by the tail. However, this could be explained by the size of the surface area available for predators to attack and does not show an attack preference. The literature does not provide any clear pattern for attack on parts of the body other than the aforementioned discussion of attacks aimed at the head. For example, when comparing the distribution of pecks along Podarcis replicas, Vervust et al. (2011) found a disproportionately high number of attacks aimed at the head and trunk, while seeing fewer attacks aimed towards the tail and limbs. While other studies have found attacks from birds predominantly across the head, tail and hind limbs (Hansen et al. 2019), and across the head/neck and trunk (Husak et al. 2006; Sato et al. 2014). Further, both Bateman et al. (2014) and Castilla et al. (1999) found attacks on all-brown replicas tended to target the head, with a high proportion of tail attacks occurring only on models with coloured tails. This lack of consistency surrounding attack site on replicas may be an artefact of attack opportunity. As previously stated, predators have one opportunity to attack prey before individuals proceed to escape. However, by providing a static replica we allow birds the opportunity to perform secondary and tertiary attacks on prey; a freedom they would not be provided in a natural situation (Rößler et al. 2018). In cases where multiple body parts have been attacked by a predator, we have no way of establishing which location was attacked first in any given 
predation event (Rößler et al. 2018). Therefore, we must be cautious about any conclusions made surrounding preference of attack by birds on other locations on the body as they may not be biologically relevant when applying to live organisms. Even if the pecks on lizard replicas were the result of exploratory behaviour from birds, rather than direct predatory behaviour, they could still result in the death of individuals.

Large birds were the predominant predators of lizard replicas within this study. Pecks from large birds accounted for approximately $57 \%$ of attacks on lizard replicas. This aligns with what we know already about avian predators within New Zealand. Many large birds have previously been observed consuming lizards, such as the weka (Gallirallus australis sp.; Coleman et al. 1983), kārearea (Falco novaeseelandiae sp.; Kross et al. 2013), kāhu (Circus approximans; Pierce \& Maloney 1989), pūkeko (Porphyrio melanotus melanotus; Carroll 1966), ruru (N. novaeseelandiae novaeseelandiae; Busbridge \& Stewart 2018) and kōtare (T. sanctus vagans; Moon 1986). Additionally, many of these species have been recorded consuming lizards on multiple occasions (Table 1.1). There are fewer and less consistent records of medium-sized birds preying on New Zealand lizards (Table 1.1) which reflects the results found in this study where fewer attacks on lizard replicas were attributed to mediumsized birds. However, this was still nearly one third of the attacks recorded on lizard replicas. The high proportion of attacks on replicas from large-beaked birds may reflect the size of potential lizard predators within the Wellington region. However, the impacts of medium birds should not be overlooked as many of these species have been introduced and are ubiquitous in the New Zealand landscape (e.g. blackbirds (Turdus merula) and starlings (Sturnus vulgaris). There is no evidence in the literature suggesting small birds within New Zealand prey on the native lizard fauna. The New Zealand pipit and fernbird are the smallest birds previously recorded eating lizards and by my beak categories they would be categorised as medium-sized birds (Eagle 2001; Ball \& Parrish 2005). Therefore, pecks from smaller birds are assumed to be a product of insects sitting on clay models (Pers. obs.) which would attract pecks from smaller, insectivorous birds such as the New Zealand fantail (Rhipidura fuliginosa sp.) or North Island robin (Petroica longipipes). Alternatively, small pecks could be the results exploratory behaviour by smaller neophilic birds. The results from this study show that large and mediumsized birds could be important predators of New Zealand lizards. 
The wider array of bird classes found interacting with control items could indicate the exploratory nature of interactions by free-ranging birds with this model type. Control items received a similar frequency of attacks from both large (34\%) and medium ( 38\%) sized birds. In comparison to lizard replicas, the proportion of large attacks was greatly reduced, but this could be explained by the frequency of stripped novel items for which beak sizes could not be determined. Additionally, control items received a higher frequency of attack by smaller birds. Consequently, there was no clear preference in the size class of birds interacting with novel items. Due to the foreign shape and nature of these cuboid models birds of all size classes may have shown an exploratory interest. However, the reduced proportion of attacks by large birds could be explained by the high proportion of stripped controls. Nearly $15 \%$ of attacks on novel items were unable to be classified to a size class as the lack of clay on the cubes left no identifying beak features (as seen previously in Low et al. 2014). As birds freely interacted with novel items, I cannot conclude that attack rates from differing bird size classes were influenced by clay model type.

In conclusion, this study shows that replicas can be used to successfully record interaction events with birds. However, these interactions cannot be confirmed as true predatory events. As such any data collected from clay model studies should be treated as an index of predation experienced by lizards. Exploratory behaviour from birds is still likely to result in the death of individuals, therefore the use of stationary replicas provides a method to investigate the pressures exploratory bird foragers exert on terrestrial lizard populations. This research shows that even short periods of exposure can provide a reasonable amount of information surrounding pressure faced by populations and potential predator identity. However, a standardised methodology for lizard replica use within New Zealand must be created in order to provide a comparative index of predation across time and space. Further research is required to separate the effects of environmental factors, such as model visibility, weather, and seasonality, on predation rates experience by lizard-replicas. Within this study assumptions rely on beak size to suggest birds interacting with replicas, and although there is confidence in determining coarse taxonomic levels of predators, this is reduced when attempting to identify attackers at a finer size class or species level (Low et al. 2014). Therefore, in order to elucidate the impacts of certain avian predators on lizards, both bird identity and abundance should also be investigated. Additionally, as predation may be an artefact of movement, prey species may not be well represented by static models. Therefore, future studies should look at using some form of movement of prey-mimicking replicas (i.e. Cain \& Cross 2019). 
CHAPTER 2: ASSESSING LIZARD REPLICA USE 


\section{Chapter 3: Habitat factors influencing the predation risk to lizards by birds in Wellington, New Zealand}

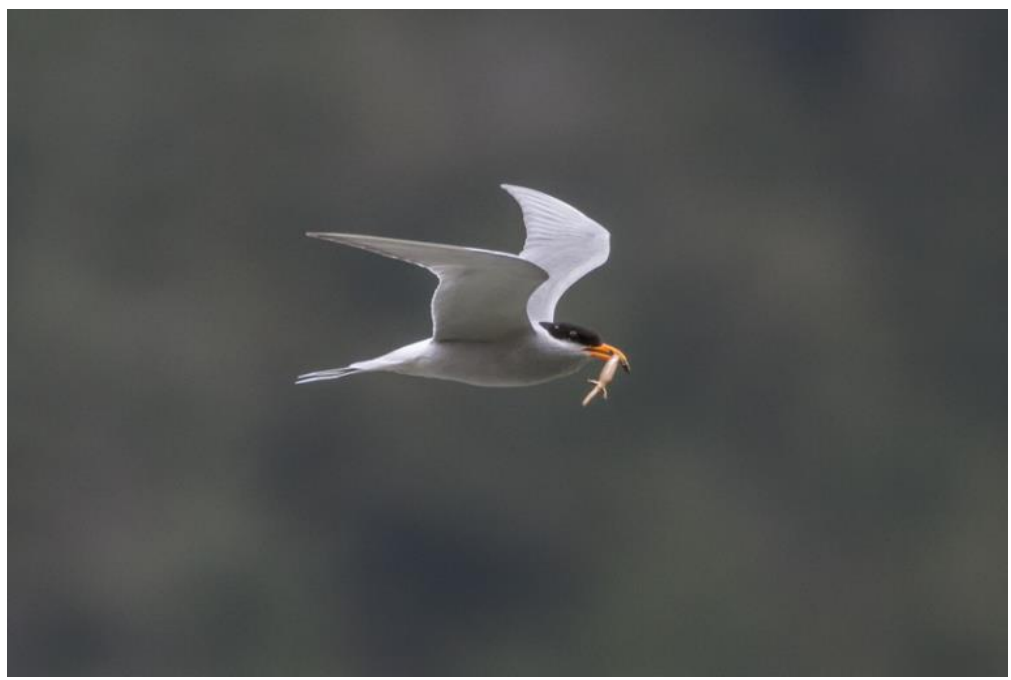

A black-fronted tern (Chlidonias albostriatus) flying with an unidentified skink in its beak in Eglinton Valley, Fiordland.

Photographed and approved for use by

Anja Kohler (October 2018).

\subsection{Introduction}

\subsubsection{The role of predation in species management}

In order for conservation actions to result in positive outcomes, it is important to identify the threats managed species or populations face within an environment (Caughley 1994; Wittmer et al. 2005). Predation provides an important source of mortality in ecosystems (Estes \& Palmisano 1974; Terborgh et al. 2001). Predators can drive the structure and composition of biological communities by influencing the abundance, diversity, distribution, and behaviour of prey populations (Paine 1966; Lima 1998). As a result, it is important to consider the influence predators may have on managed populations to avoid the decline or extirpation of prey (e.g. McLennan et al. 1996). However, predation pressure is not always distributed uniformly across time and space. The predation risk experienced by prey can change due to differences in the assemblage or abundance of predators, or the habitat use and foraging strategies they exhibit (e.g. Pérez-Mellado et al. 2014). Prey themselves can alter risk through morphological and behavioural traits that determine if and how predators detect and interact with individuals 
(Brown 1999; Webb \& Whiting 2005; Bateman et al. 2014). Additionally, the habitat itself can influence the predation risk of species by offering refugia to prey, or influencing the detection rates of prey by predators and vice versa (Shepard 2007; Chalfoun \& Martin 2009; McMillan \& Irschick 2010; Seymoure et al. 2018). It is evident many factors can influence how predators and prey interact within an environment. Understanding the impact of specific predators and the role habitat plays in predation risk can help inform the management of both predator and prey species at specific sites and reduce the risk of negative conservation outcomes.

\subsubsection{Predation risk for New Zealand lizards}

New Zealand's native herpetofauna is highly vulnerable with $87 \%$ of the $100+$ species considered 'At Risk' or 'Threatened' under the New Zealand Threat Classification System (Hitchmough et al. 2015). One of the main methods employed to conserve this fauna is the eradication or suppression of mammalian predators (Towns \& Daugherty 1994; Reardon et al. 2012; Monks et al. 2014). Many lizard species have been translocated to offshore islands and mainland ecosanctuaries where sustained mammalian predator control is possible (Romijn \& Hartley 2016). Although these places provide refuge from mammalian predators, they only represent a fraction of the habitat that could be used for the conservation of species (Russell et al. 2015). Consequently, in 2012 the Predator Free New Zealand (PFNZ) campaign was announced that has the goal of eradicating the eight mammalian predators considered to be the biggest threat to native species (Mus musculus, Rattus exulans, R. norvegicus, R. rattus, Mustela erminea, M. furo, M. nivalis, and Trichosurus vulpecula) (Russell et al. 2015; Owens 2017). However, the removal of predators from ecosystems often comes with unexpected and unintended consequences, especially if eradication of predators does not occur simultaneously (Zavaleta et al. 2001; Ruscoe et al. 2011). While the risk of mammalian mesopredator or competitive release has been recognised, little work has been done to investigate the release of other predator groups and the potential pressures they may exert on prey species (Ruscoe et al. 2011; Russell et al. 2015). The removal of mammalian predators has been shown to increase the nesting success and survival of many forest birds and, consequently, bird populations are expected to flourish post-eradication (Innes et al. 2010). An increase in population numbers or birds poses a risk to the smaller endemic species on which they prey, such as lizards and invertebrates (Watts et al. 2014; Hitchmough et al. 2016a). 


\subsubsection{Quantifying avian predation within New Zealand}

Avian predation pressure on lizard populations has not been widely investigated within New Zealand. Previous work has looked at assessing the avian predation risk to colour and pattern morphs of the shore skink, Oligosoma smithi, within differing vegetation backgrounds (Baling 2017). While the study reported $40.4 \%$ of the 240 lizard-mimicking replicas were pecked during their 12 days of exposure, the author did not provide a measure of daily predation which reduces the comparative ability of this research. Additionally, the avian predators interacting with lizard replicas were not identified. However, another study found that avian predation did not significantly influence the survival of jewelled geckos, Naultinus gemmeus, across bird exclusion and inclusion zones (Schneyer 2001). Within New Zealand, at least 31 bird species prey on our native lizard fauna, however, the effects of these species has not yet been widely quantified (see Table 1.1 and Hare et al. 2016). For example, the morepork (Ninox novaeseelandiae novaeseelandiae) and New Zealand kingfisher (Todiramphus sanctus vagans), were assumed important predators of lizards due to the multitude of lizard predation observations involving these species (Table 1.1; van Winkel \& Ji 2012). However, it is only recently that the frequency of lizard consumption by these species at particular sites has been quantified (van Winkel \& Ji 2012). Dietary analyses on a New Zealand kingfisher population on Tiritiri Matangi Island found up to $88 \%$ of the pellets analysed showed remains of lizards, with an additional $43 \%$ of pellets from the Motuora Island population containing lizard remains (van Winkel \& Ji 2012).

\subsubsection{Conservation challenges for New Zealand lizards}

When managing species for conservation it is critical to consider population trends and predation pressure experienced by populations to avoid negative conservation outcomes (Saunders et al. 2018). Many New Zealand lizard species found on the mainland are restricted to small or relict populations, and founder populations for island translocations are often small due to limits posed by captive breeding or harvest restrictions (Baling et al. 2013; Hitchmough et al. 2016b). Further, the majority of New Zealand's most vulnerable lizard species show relatively slow life histories with low rates of reproduction and long gestational periods (e.g. 1.12 offspring/female/year for Hoplodactylus duvaucelii and 2.34 offspring/female/year for Oligosoma otagense; Cree 1994). These K-selected traits leave them particularly at risk as population sizes are slow to recover from population-reducing stochastic events, such as predation or demographic shift, and this is often compounded by their isolation from 
metapopulations (Soule 1985; Caughley 1994; Baling et al. 2013). Predation can decrease the genetic diversity or effective population size of prey species, and reduce long-term population viability, and the loss of one individual has greater effects on smaller populations (Caughley 1994; McLennan et al. 1996). This cost may become two-fold if gravid lizards, which bask for extended periods for the development of young, are lost from the population (Cree \& Hare 2016). As a result, even episodic bouts of predation are likely to cause declines in vulnerable lizard populations or affect the success of translocations (Reardon et al. 2012; Baling et al. 2013). This may be the case in the Rotoiti Nature Recovery Project where mammalian predator suppression alone was an insufficient measure in reducing the population decline of skinks (Dumont 2015). As such, more research needs to be conducted into looking at other factors influencing populations and their persistence within environments.

I investigated predation pressure and predation rates within and among sites to understand mechanisms driving avian predation on lizard populations in the Wellington region. My specific questions included:

- How does avian predation on lizard replicas differ across and among sites around Wellington?

- What birds are present at these sites, and which bird species are interacting with lizard replicas?

- Are beak marks left on replicas identifiable to species?

- Was predation on individual replicas influenced by habitat or weather variables?

\subsection{Methodology}

I deployed a total of 330 lizard-mimicking replicas using peck marks to assess avian predation on New Zealand lizard populations. The methods of replica creation, deployment, and monitoring are fully described in Chapter 2. I chose four locations within the Wellington Region, New Zealand, to represent predation across a wide array of environments: Mana Island, Matiu/Somes Island, southern Miramar Peninsula, and Zealandia Ecosanctuary (Figure 2.1). A total of 11 replicates were achieved among research locations, with 30 lizard replicas used within each replicate (Table 2.1). Three habitat sites were chosen within each location, for a total of 12 sites, to capture the variation in habitat and bird communities that may occur within overarching locations. 


\subsubsection{Research locations and habitat sites}

See Chapter 2 for descriptions and locations of all four research locations used within this study. The complete lizard fauna present at each location is also described in Chapter 2.

I chose three habitat sites on Mana Island ( $\left.41^{\circ} 05^{\prime} 24.4^{\prime \prime S} 174^{\circ} 46^{\prime} 52.3^{\prime \prime E}\right)$ to encompass both the forested and coastal habitats (Figure 3.1). The Shingle Point site comprised a mosaic of large open rocky areas and vegetative pockets, with vegetation a mixture of native shrubs and vines, small trees, and introduced grasses (e.g. Muehlenbeckia spp., Tetragonia spp., Coprosma repens). The gecko Woodworthia maculata was abundant at this site, taking refuge within gaps of the rocky substrate (Pers. obs.). In comparison, the site at hole-in-rock beach had larger areas of open space with reduced complex vegetation, comprising low lying Coprosma shrubs. Wètā Valley was the only forested site, comprising a mixture of Cupressus macrocarpa and regenerating native tree cover (e.g. Pseudopanax arboreus, Leptospermum scoparium, Kunzea ericoides, and Melicytus ramiflorus). Wētā Valley was chosen as translocations of both

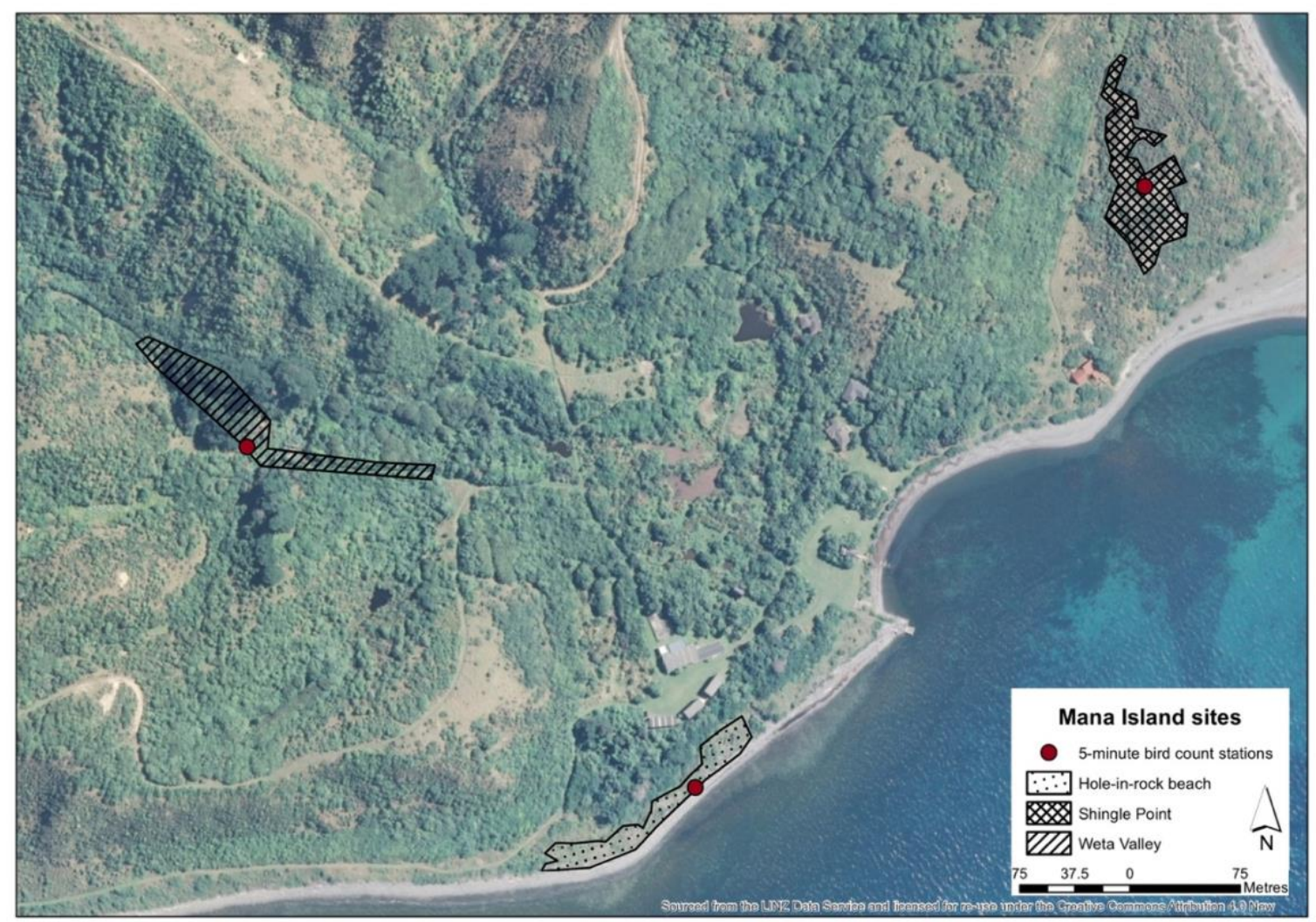

Figure 3.1: Map of the three study sites used on Mana Island. Individual sites are marked by patterned polygons, with the approximate location of each site's bird count station indicated by a red circle. Created using Esri ${ }^{\circledR}$ ArcMap $^{\mathrm{TM}}$ v.10.6.1. Base map sourced from LINZ Data Service. 
Wellington green geckos (Naultinus punctatus) and speckled skinks (Oligosoma infrapunctatum) have occurred within the valley (Miskelly 2010; Sherley et al. 2010).

Matiu/Somes Island ( $\left.41^{\circ} 15^{\prime} 29.5^{\prime \prime S} 174^{\circ} 51^{\prime} 57.2^{\prime E}\right)$ is a 29.4 -ha historic and scientific reserve owned by Taranaki Whānui and managed by DOC, located in Wellington Harbour, $8 \mathrm{~km}$ from the city centre. The landscape consists of a mixture of pioneer and coastal forest, cliff communities, grazing pasture, and wetlands (Department of Conservation 2000). I chose the area adjacent to the historical northern wharf as a site due the high frequency of skinks (Oligosoma kokowai) observed basking. The site encompassed the path and beach areas north and south of the currently used wharf, as such vegetation largely comprised introduced grasses, native flaxes, and Coprosma repens shrubs (Figure 3.2). The second site was located along the southern walkway, and again was chosen due to the high density of basking skinks observed on the edge of paths. The third habitat site, bunker paddock was an open grass pasture, browsed by sheep, located at the summit of the island. 


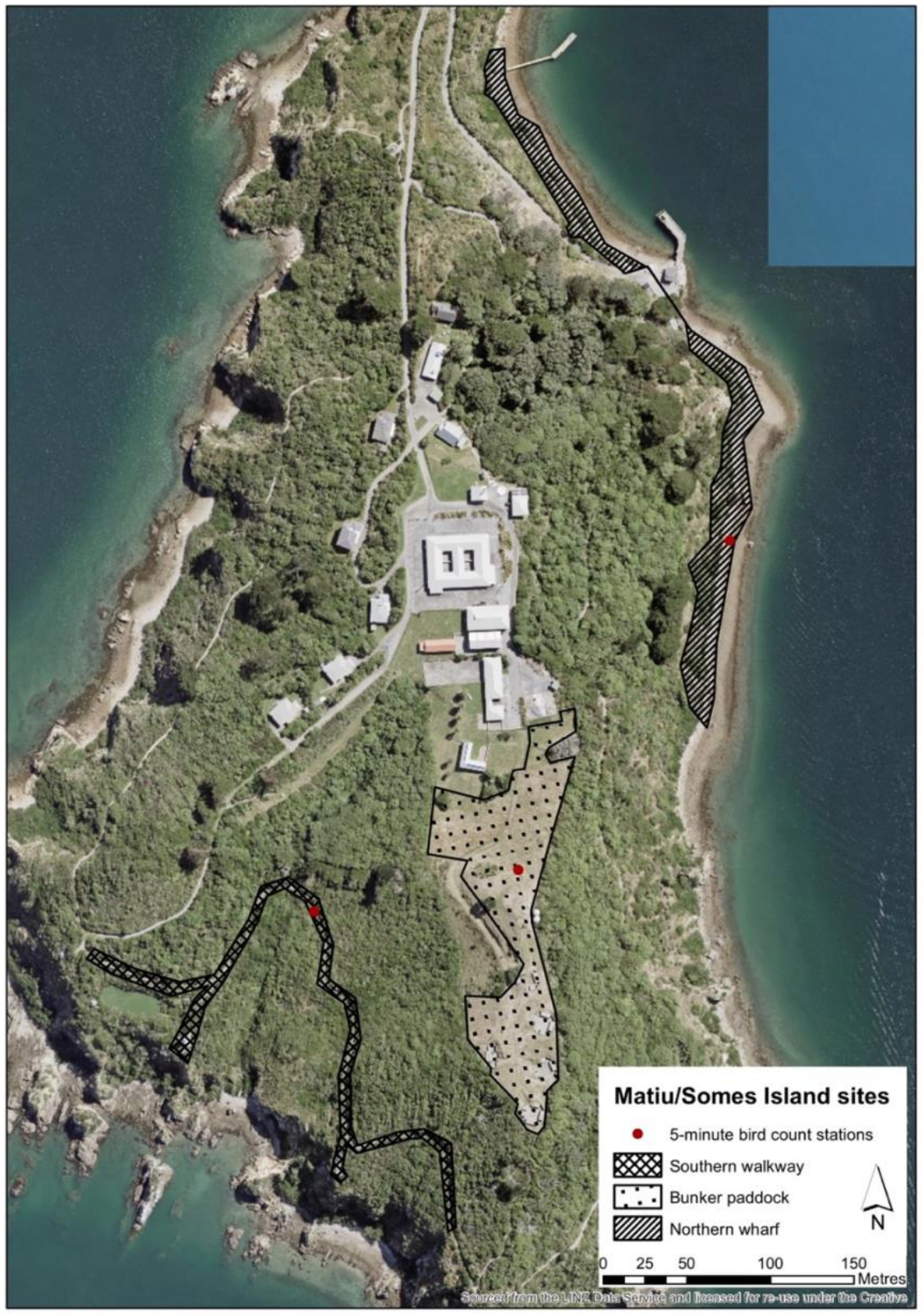

Figure 3.2: Map of the three study sites used on Matiu/Somes Island. Individual sites are marked by patterned polygons, with the approximate location of each site's bird count station indicated by a red circle. Created using Esri® ArcMap ${ }^{\mathrm{TM}}$ v.10.6.1. Base map sourced from LINZ Data Service.

Miramar Peninsula (41 $\left.17^{\prime} 26.2^{\prime \prime S} 174^{\circ} 49^{\prime} 32.2^{\prime \prime E}\right)$ spans 800 ha east of central Wellington and comprises a mix of residential, industrial, and green spaces (reserves and parks). I chose the three habitat sites along the southern coastline to encompass both coastal and reserve habitats. All sites are publicly accessible (Figure 3.3). The Wahine Park site was coastal with very little vegetation (introduced grasses, native flaxes, Coprosma spp.). The second site, Moa Point, is a small land mass that is surrounded by water except during low tide, with vegetation similar 
to Wahine Park: a mixture of native flax bushes, introduced grasses, and native shrubs (e.g. Coprosma repens). W. maculata and $O$. polychroma have been detected in very low numbers at both coastal sites (S. Herbert, unpubl. data). The Rangitatau Reserve site was located on the southern periphery of the reserve, comprising grassy vegetation with small trees/shrubs. Both northern grass skinks (Oligosoma polychroma) and copper skinks (O. aeneum) were frequently observed basking at this site (Pers. obs.) and have been detected in low numbers (S. Herbert, unpubl. data).

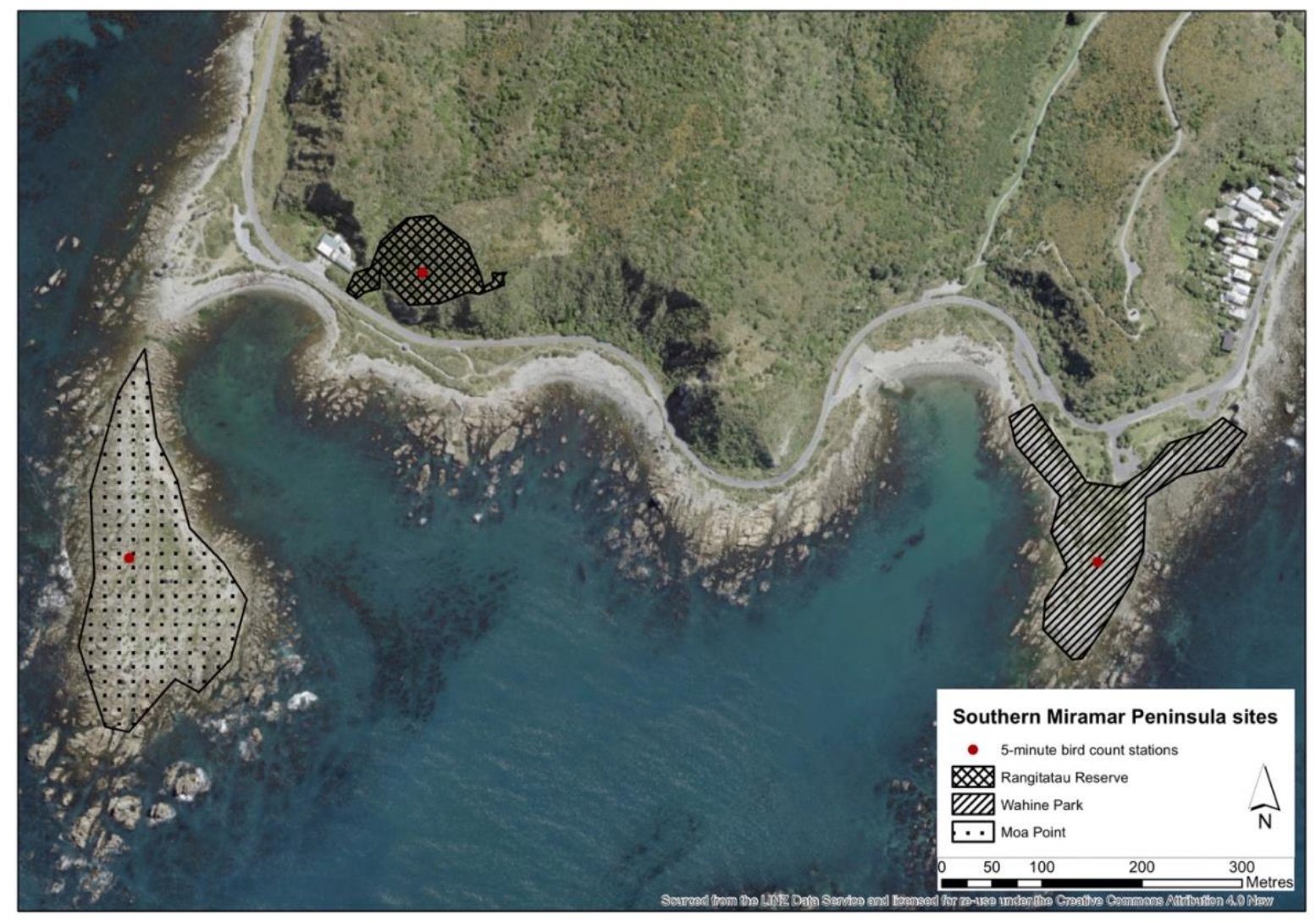

Figure 3.3: Map of the three study sites used on the southern end of Miramar Peninsula. Individual sites are marked by patterned polygons, with the approximate location of each site's bird count station indicated by a red circle. Created using Esri ${ }^{\circledR}$ ArcMapp $^{\mathrm{TM}}$ v.10.6.1. Base map sourced from LINZ Data Service.

Zealandia Ecosanctuary $\left(41^{\circ} 17^{\prime} 26.9^{\prime \prime S} 174^{\circ} 45^{\prime} 12.2^{\prime \prime E}\right)$, is a 225 -ha "mainland island" located southwest of Wellington central in the suburb of Karori. The three habitat sites were located in the northern section of the sanctuary, spanning from the main trail through to the eastern perimeter fence (Figure 3.4). The first site is located in the research area, a fenced location that excludes mice. The second site is located on a slope adjacent to the research enclosure. Both 
sites were chosen are they are known release and monitoring sites for translocated populations of northern spotted skinks (O. kokowai) (Shanahan et al. 2019). The final site is located along the inside track of the eastern perimeter fence, largely comprising forest edge habitat and an open grassy trail. I chose this site as it offered habitat for both semi-fossorial and terrestrial lizard species, such as $O$. aeneum and $O$. polychroma.

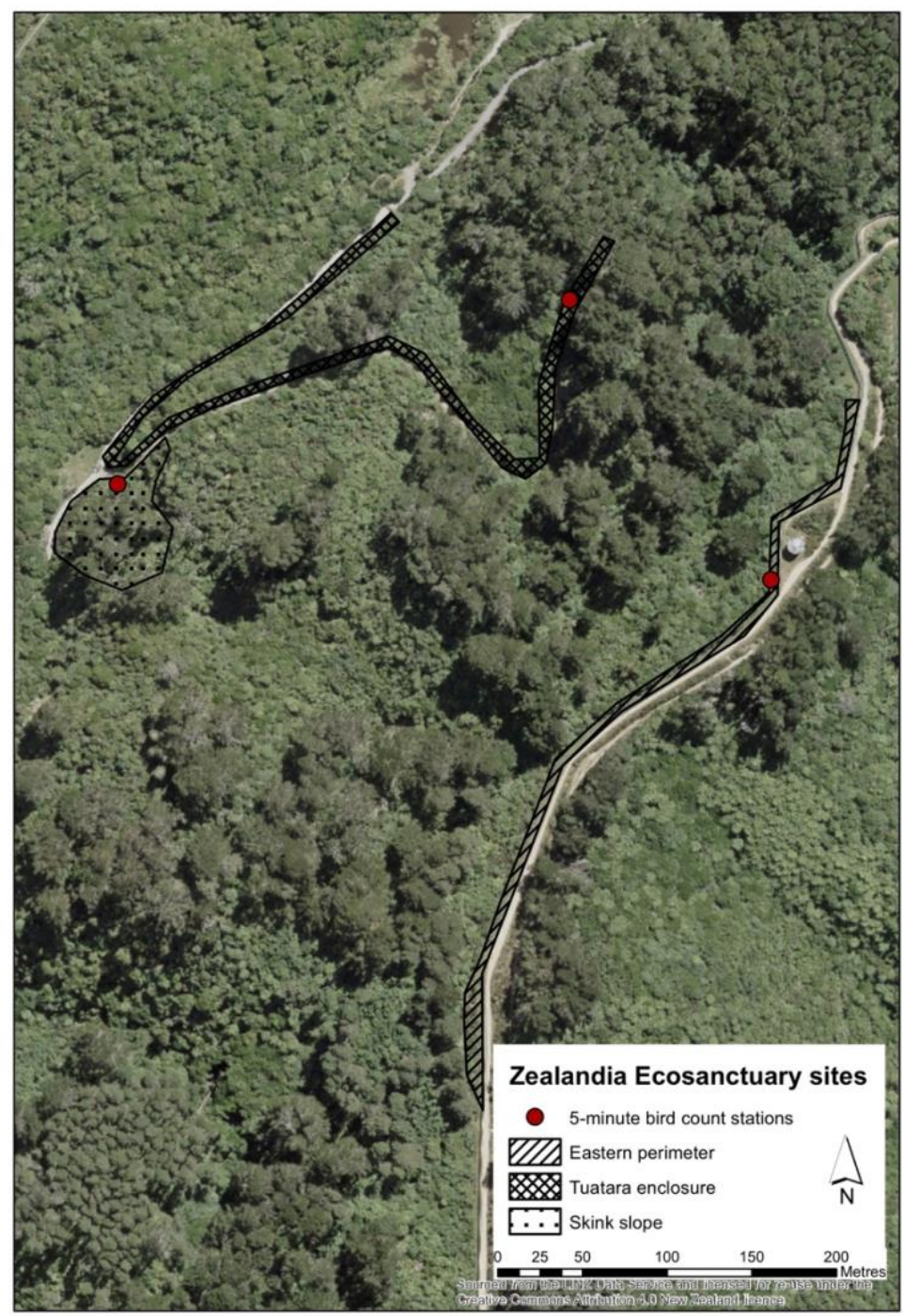

Figure 3.4: Map of the three study sites used within Zealandia Ecosanctuary. Individual sites are marked by patterned polygons, with the approximate location of each site's bird count station indicated by a red circle. Created using Esri ${ }^{\circledR}$ ArcMap $^{\mathrm{TM}}$ v.10.6.1. Base map sourced from LINZ Data Service. 


\subsubsection{Identification of potential predators}

\subsubsection{Five-minute bird counts}

I conducted five-minute bird counts to establish an index for bird species diversity, presence, and relative abundance within and among research locations to aid identification of avian predators, as suggested in Low et al. (2014). I used a modified Dawson \& Bull (1975) method, in which an unbounded count of all birds seen and heard was recorded for five-minute periods, rather than limiting birds seen and heard to within a bounded $200 \mathrm{~m}$ radius. I chose this altered method as it is difficult to establish at what distance birds are calling from. Additionally, it is the primary method used within New Zealand to identify the relative abundance and presence of species within and among locations (Hartley 2012). I established twelve bird count stations, one at each habitat site (Table 3.1). I conducted bird counts daily at the three habitat sites where replicas were deployed during each replicate. The distance between research locations was too large to conduct counts across all habitat sites on a daily basis. I took additional counts when able on replica deployment and collection days. All counts were conducted between 0730 and 1700 NZST during the replica checks in order to avoid multiple disturbances of the bird assemblages. Care was taken to track individuals during each five-minute bird count so that individuals were not recorded multiple times. This was done to increase the confidence in the estimation of relative abundance of species across sites, but it is still likely that some individuals were recorded multiple times across the span of a single count. Additionally, I audio-recorded all bird calls during counts in order to reduce observer error by allowing playback to confirm the identification of bird species.

To ensure the study sites could be assumed independent from one another under the methods of Dawson \& Bull (1975), I measured the distance between five-minute bird count stations post-hoc. Bird count stations at both Zealandia Ecosanctuary and Matiu/Somes Island were less than $200 \mathrm{~m}$ from each other. At Matiu/Somes Island, the distance between the Bunker Paddock and the Southern Walkway stations was $98 \mathrm{~m}$. At Zealandia, the Tuatara Enclosure was not independent of either the Eastern Perimeter (155 m) or Skink Slope (131 m) sites. It is likely that these sites share the same presence and abundance of bird species. However, within the results I have reported sites independently as I assume that habitat differences among sites will influence the bird assemblages using each site. 
Table 3.1 - Locations of the five-minute bird count stations. Sample size refers to the number of counts conducted at each station. Replicate numbers are the dates repeated bird count samples were taken for replicates at each site (not necessarily the same dates that replicas were deployed). All counts occurred in 2019.

\begin{tabular}{|c|c|c|c|c|c|c|c|c|}
\hline \multirow[b]{2}{*}{ Location } & \multirow[b]{2}{*}{ Station/site name } & \multirow[b]{2}{*}{ Coordinates } & & \multirow[b]{2}{*}{$\begin{array}{l}\text { Sample } \\
\text { size }\end{array}$} & \multicolumn{4}{|c|}{ Dates of bird count sampling } \\
\hline & & & & & Replicate 1 & Replicate 2 & Replicate 3 & Replicate 4 \\
\hline \multirow{3}{*}{ Mana Island } & Shingle Point & $41^{\circ} 5^{\prime} 25^{\prime} ’ \mathrm{~S}$ & $174^{\circ} 47^{\prime} 16^{\prime \prime} \mathrm{E}$ & 18 & $24-27^{\text {th }}$ Jan & $28^{\text {th }}$ Jan- $1^{\text {st }}$ Feb & $7-11^{\text {th }} \mathrm{Feb}$ & $12-15^{\text {th }}$ Feb \\
\hline & Wētā Valley & $41^{\circ} 5^{\prime} 32^{\prime} \mathrm{S}$ & $174^{\circ} 46^{\prime} 53^{\prime \prime} \mathrm{E}$ & 19 & $24-27^{\text {th }}$ Jan & $28^{\text {th }} \mathrm{Jan}-1^{\text {st }}$ Feb & $6-10^{\text {th }} \mathrm{Feb}$ & $11-15^{\text {th }}$ Feb \\
\hline & Hole-in-rock Beach & $41^{\circ} 5^{\prime} 39^{\prime \prime} \mathrm{S}$ & $174^{\circ} 47^{\prime} 3^{\prime \prime} \mathrm{E}$ & 18 & $25-28^{\text {th }}$ Jan & $29^{\text {th }}$ Jan- $1^{\text {st }}$ Feb & $6-10^{\text {th }} \mathrm{Feb}$ & $11-15^{\text {th }}$ Feb \\
\hline \multirow{3}{*}{$\begin{array}{l}\text { Matiu/Somes } \\
\text { Island }\end{array}$} & Northern Wharf & $41^{\circ} 15^{\prime} 25^{\prime \prime} \mathrm{S}$ & $174^{\circ} 52^{\prime} 3^{\prime \prime} \mathrm{E}$ & 10 & $1^{\text {st }}-5^{\text {th }}$ Mar & $16-20^{\text {th }}$ Mar & & \\
\hline & Southern Walkway * & $41^{\circ} 15^{\prime} 32^{\prime} \mathrm{S}$ & $174^{\circ} 51^{\prime} 53^{\prime \prime} \mathrm{E}$ & 10 & $1^{\mathrm{st}}-5^{\mathrm{th}} \mathrm{Mar}$ & $16-20^{\text {th }}$ Mar & & \\
\hline & Bunker Paddock * & $41^{\circ} 15^{\prime} 31^{\prime \prime} \mathrm{S}$ & $174^{\circ} 51^{\prime} 57^{\prime \prime} \mathrm{E}$ & 10 & $1^{\text {st }}-5^{\text {th }}$ Mar & $16-20^{\text {th }}$ Mar & & \\
\hline \multirow{3}{*}{$\begin{array}{l}\text { Southern Miramar } \\
\text { Peninsula }\end{array}$} & Wahine Park & 41²0’39”S & $174^{\circ} 49^{\prime} 16^{\prime \prime} \mathrm{E}$ & 9 & $20-24^{\text {th }}$ Feb & $9-12^{\text {th }}$ Feb & & \\
\hline & Rangitatau Reserve & $41^{\circ} 20^{\prime} 29 ’ \mathrm{~S}$ & $174^{\circ} 48^{\prime} 46^{\prime \prime} \mathrm{E}$ & 9 & $20-24^{\text {th }}$ Feb & $9-12^{\text {th }}$ Feb & & \\
\hline & Moa Point & $41^{\circ} 20^{\prime} 39^{\prime \prime} \mathrm{S}$ & $174^{\circ} 48^{\prime} 34^{\prime \prime} \mathrm{E}$ & 8 & $20-24^{\text {th }}$ Feb & $9-11^{\text {th }} \mathrm{Feb}$ & & \\
\hline \multirow{3}{*}{$\begin{array}{l}\text { Zealandia } \\
\text { Ecosanctuary }\end{array}$} & Eastern Perimeter $*$ & $41^{\circ} 17^{\prime} 47^{\prime \prime} \mathrm{S}$ & $174^{\circ} 45^{\prime} 5^{\prime \prime} \mathrm{E}$ & 14 & $18^{\text {th }}-21^{\text {st }}$ Jan & $23^{\text {rd }}-27^{\text {th }}$ Apr & $1^{\text {st }}-5^{\text {th }}$ May & \\
\hline & Tuatara Enclosure * & $41^{\circ} 17^{\prime} 43^{\prime \prime S}$ & $174^{\circ} 45^{\prime} 1^{\prime \prime} \mathrm{E}$ & 14 & $18^{\text {th }}-21^{\text {st }}$ Jan & $23^{\text {rd }}-27^{\text {th }}$ Apr & $1^{\text {st }}-5^{\text {th }}$ May & \\
\hline & Skink Slope * & $41^{\circ} 17^{\prime} 46^{\prime \prime} \mathrm{S}$ & $174^{\circ} 44^{\prime} 53^{\prime \prime} \mathrm{E}$ & 14 & $18^{\text {th }}-21^{\text {st }}$ Jan & $23^{\text {rd }}-27^{\text {th }}$ Apr & $1^{\text {st }}-5^{\text {th }}$ May & \\
\hline
\end{tabular}

* Stations located less than $200 \mathrm{~m}$ from another station. 


\subsubsection{Motion-sensitive cameras}

During replica deployment, I used motion-sensitive trail cameras (Bushnell Trophy Camera Brown, Model 119436) to capture predation attempts on lizard replicas and aid the identification of bird predators. I placed two cameras per habitat site for a total of six cameras in use across each research location during each replicate. I set cameras at the highest motion sensitivity with three photos taken, each one second apart when triggered. I moved cameras between lizard replicas at each site to increase the number of attack events being captured on camera.

I visually assessed each photo for the presence of birds interacting with lizard replicas. I only assigned a predation event to a bird if the direct interaction with a lizard replica was caught on camera. I identified all camera interactions to species level. I assigned 'not visible' to interactions that were not caught by the camera, and 'unconfirmed' if the species interacting was unable to be confidently assigned due to the lack of direct contact with a lizard replica, or the presence of multiple species.

\subsubsection{Peck identification}

I used the peck imprints left in the replica clay coating to identify the bird species interacting with lizard replicas that were not previously identified by the cameras. I used the predation events caught on camera to help correctly assign predation marks to particular species, as suggested by Low et al. (2014). Additionally, I used the results from the five-minute bird counts to identify predators that were available to interact with replicas across each site increasing the confidence in predator identification.

As there is a lack of information regarding the identification of predation marks on replicas across other studies, I have provided a figure within the results section detailing the peck marks left by bird species within this research (Figure 3.14). Species were identified using individual pecks on replicas with the level of pecking not included in identification methods. It must be noted that other factors likely to influence identification efforts include the ambient temperature influencing the malleability of clay and the level of interaction by the bird, i.e. tentative or aggressive attacks (Low et al. 2014; Muchula et al. 2019). 


\subsubsection{Environmental data collection}

\subsubsection{Weather data}

I retrieved weather data for research locations from NIWA's CliFlo database (http://cliflo.niwa.co.nz/, retrieved 25-September-2019), using the closest weather station to each research location (Table 3.2). I chose four variables: maximum gust, fixed period rainfall, and minimum and maximum temperature. I assumed these weather conditions would influence the activity of birds within an area and therefore influence their interaction rates with lizard replicas. Hourly values were unavailable for the chosen stations, so values were calculated daily at 0900 NZST, accounting for the previous 24 hours of exposure for lizard replicas. Maximum gust (metcode $=141$ ) was calculated daily in kilometres per hour. Rainfall (metcode $=181$ ) in millimetres is measured over a 24-hour period. Minimum and maximum temperature (metcode $=201)$ records the extreme temperatures during a fixed 24-hour period with values recorded in ${ }^{\circ} \mathrm{C}$.

Table 3.2 - The four weather stations assigned to each research location based on proximity to sites. Weather data for research locations were collected from CliFlo NIWA's National Climate database (http://cliflo.niwa.co.nz/, retrieved 25/09/2019).

\begin{tabular}{lll}
\hline Research location & Station name (number) & Coordinates Lat, Lon \\
\hline Mana Island & Mana Island Aws (25531) & $-41.08675,174.78004$ \\
Matiu/Somes Island & Wellington, Greta Point Cws (41212) & $-41.30243,174.80574$ \\
Southern Miramar Peninsula & Wellington Aero (3445) & $-41.322,174.804$ \\
Zealandia Ecosanctuary & Wellington, Kelburn Aws (25354) & $-41.285,174.768$ \\
\hline
\end{tabular}

\subsubsection{Vegetation characteristics}

I measured two vegetation characteristics for each lizard replica deployed: distance to nearest vegetation and canopy cover above replica site. I made the assumption that these two covariates influence the visibility of lizard replicas to foraging predators. Habitat data were replica specific for analysis purposes.

During deployment, I measured the distance, to the nearest $\mathrm{cm}$, from each replica to the nearest vegetation. Any measurements over 15 metres were capped and recorded as 15 metres. I only included vegetation that was at least one metre in height. 
I estimated canopy cover for each lizard replica using digital canopy cover photography. I placed a camera at ground level at the exact location of replica deployment and took one photo facing the canopy. Photos were taken using a front-facing 5-megapixel phone camera (iPhone 6s front camera, $2.65 \mathrm{~mm} \mathrm{f} / 2.2$ ) which provides enough detail for binary pixel computation. I processed photos through Hemispherical_2.0 (Beckschäfer 2015), a plugin for ImageJ 1.52q (https://imagej.nih.gov/ij/; Schneider et al. 2012). Hemispherical_2.0 splits images into the RGB colour plane using the blue spectrum to allow the greatest contrast between sky and vegetation. A binary file is then produced classifying canopy gaps as white pixels and vegetation as black pixels (see Figure 3.5). The software provides an output of 'gap_fraction' which is calculated as the percentage of pixels in gaps versus non-gaps. I subtracted gap_fraction from 100 to produce a percentage of canopy cover for each replica.

As the software uses the blue colour plane to contrast vegetation against sky, when vegetation is not present the software can become highly inaccurate - using differences in sky colour (i.e. clouds, sun glare) to calculate measurements. Therefore, I visually assessed photos before processing and any photos containing zero canopy were classified as $0 \%$ immediately. Moreover, to negate pixel classification errors, Hemispherical_2.0 produces binary photos of the classified vegetation/sky that allows the visual comparison to original photos to identify any misclassifications. I also compared binary photos to the original and excluded any canopy cover estimates that were inaccurate (i.e. misclassification of the sky as canopy). I was unable to exclude artificial structures, such as fences, from the Hemispherical_2.0 calculations so these were classified as canopy.

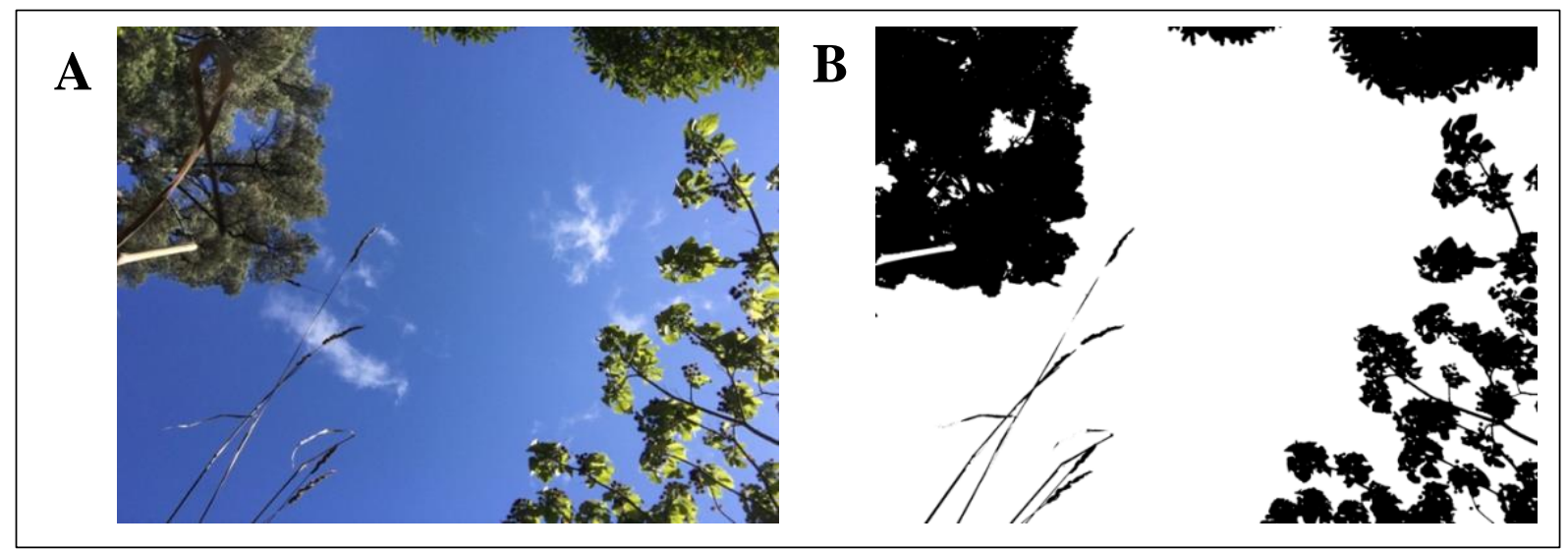

Figure 3.5: Example of a canopy cover image and the processed Hemispherical_2.0 binary file. Image A shows the original canopy cover photograph taken in-field. Image B shows the binary pixel file produced by the Hemispherical_2.0 plugin for ImageJ. 


\subsubsection{Statistical analysis}

Five-minute bird count data were manipulated into presence/absence and relative abundance data for each bird species encountered at each of the twelve sites. The presence data was calculated as a percentage by dividing the number of counts a particular bird species was marked present at a site by the total number of counts conducted at that site (\# of counts spp. present at site / total \# counts at site). The relative abundance of each bird species at a site was calculated as the average number of individuals of a particular species seen each count at a site. Relative abundance was calculated by averaging the number of individuals in a species encountered at a site by the total number of counts conducted at that site (total \# of individuals encountered / total \# counts).

Data were broken down into daily predation checks for each lizard replica leaving 1250 daily checks across 330 lizard replicas. Habitat data (canopy cover and distance to vegetation) were assigned to each lizard replica and values did not alter across the period of exposure. Weather data were assigned daily and were location specific. All analyses were done in R v.3.6.1 ( $R$ Core Team, Vienna, Austria). All graphs were created using the ggplot2 package in $\mathrm{R}$ (Wickham 2016).

Environmental variables from this data were processed through a pairwise Spearman Rho correlation matrix, using the rcorr function from the Hmisc-package, to identify correlated factors that can be excluded from the generalised mixed linear model (Table 3.3). Missing (NA) canopy cover values are deleted in a pairwise manner by the software rather than the whole data row, allowing the maximum output for each variable. Thirteen interactions were identified as significantly correlated however this likely an artefact of large sample size. Therefore, I decided to avoid factors that were strongly correlated (i.e. $>|0.6|$ ). Distance to vegetation and canopy cover were identified as strongly correlated. I decided to exclude distance to vegetation, as canopy cover is more likely to influence the visibility of replicas to foraging birds. Minimum and maximum temperatures were also strongly correlated. I chose to use maximum temperature as lizards are more likely to be available to bird predators during warmer weather when they are exposing themselves to bask. 
Table 3.3 - Correlation coefficients from the pairwise Spearman Rho correlation of numeric environmental factors. Bold values indicate statistically significant correlations.

\begin{tabular}{|c|c|c|c|c|c|c|}
\hline & \multicolumn{6}{|c|}{ Environmental factors } \\
\hline & Dist.to.veg & Canopy.cover & Max.gust & Daily.rain & Max.temp & Min.temp \\
\hline \multicolumn{7}{|l|}{ Dist.to.veg } \\
\hline Canopy.cover & -0.71 & & & & & \\
\hline Max.gust & 0.08 & 0.06 & & & & \\
\hline Daily.rain & -0.07 & 0.12 & 0.13 & & & \\
\hline Max.temp & 0.15 & -0.18 & 0.02 & -0.4 & & \\
\hline Min.temp & 0.23 & -0.17 & 0.36 & -0.36 & 0.7 & \\
\hline
\end{tabular}

I used the glmer function from the lme4-package to analyse the binary response predation data ('Attacked'/ 'Not attacked') using generalised linear mixed models (GLMM) with random effects (Bates et al. 2015). The random fixed effects included in each model were site (12 levels) and replica identity (330 levels). The inclusion of replica identity was to account for the multiple checks conducted across exposure days for each replica. To determine the influence of external variables on bird predation I used a global additive model:

$$
\begin{gathered}
\text { predation } \sim \text { canopy.cover }+ \text { max.temp }+ \text { daily.rainfall }+ \text { max.gust }+ \text { lizard.preds }+ \\
(1 \mid \text { site / replicalD })
\end{gathered}
$$

The initial GLMM failed to converge, so I used the bobyqa optimizer from the minqa-package to increase the number of iterations (maxfun $=2 \mathrm{e} 5$ ) to allow glmer model convergence (Powell 2009). Additionally, the factors canopy.cover, max.temp, max.gust, and lizard.preds were found to correlate with the model intercept so they were transformed using Z-score standardisation. As the variable transformation altered the original scale (a change of 1 unit is a change of one standard deviation) I reported the trend of variables rather than the estimates.

\subsection{Results}

\subsubsection{Attacks on replicas by site}

I excluded predation data for ten lizard replicas from the second Miramar replicate from analyses, as a sewage spill left the site inaccessible for 48 hours. However, I was able to include data from this site for the two days prior when the site was still accessible. Lizard replicas were exposed for a total of 1250 days and attracted 153 predation events across 144 days. I took the daily average proportion of lizard replicas attacked within each site to produce site-specific 
interaction rate. Overall, predation varied greatly within and among research areas (Figure 3.6). The highest daily predation rates were seen at sites within Matiu/Somes Island (Bunker Paddock 0.25 \pm 0.06), Mana Island (Hole-in-rock Beach $0.25 \pm 0.03$ ), and Miramar (Moa Point $0.20 \pm 0.06$ ). Comparatively, interaction rates of lizard replicas at sites within Zealandia Ecosanctuary were low ( $<0.05$ replicas per day). Furthermore, replicas at both the Rangitatau Reserve and Eastern Perimeter received no attacks by avian predators.
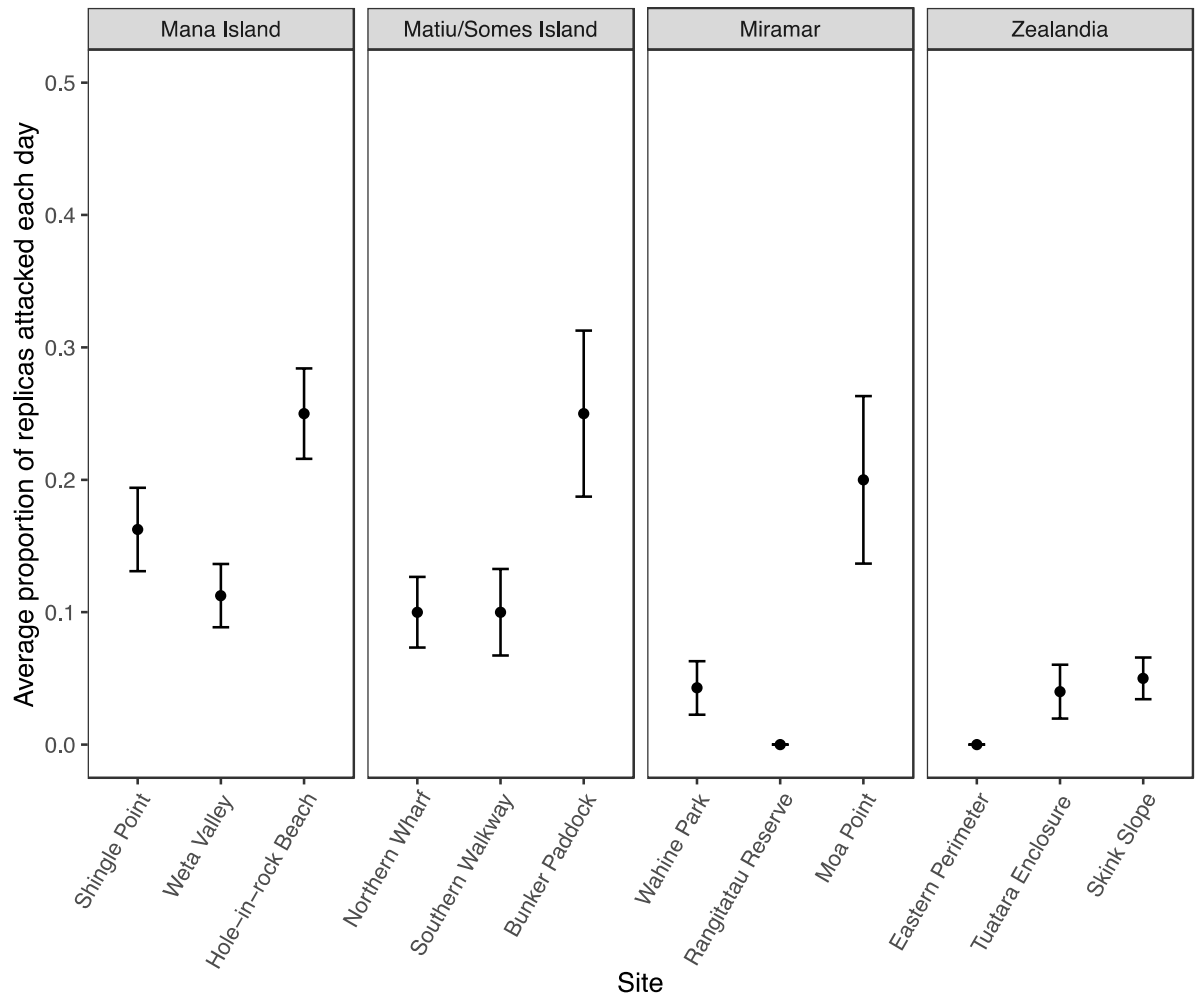

Figure 3.6: The average proportion of lizard replicas attacked daily at each habitat site. Error bars represent one standard error of the mean. Attack rates were calculated by averaging the proportion of lizard replicas attacked each day during replica exposure.

\subsubsection{Habitat characteristics of sites}

The distance of lizard replicas to the nearest patch of vegetation differed greatly within research areas (Figure 3.7). Sites at Miramar Peninsula showed the largest variation in distance to vegetation across sites, with replicas sitting in closer proximity to vegetation at Rangitatau Reserve $(1.8 \pm 0.15 \mathrm{~m})$ than Wahine Park or Moa Point $(5.4 \pm 1.2 \mathrm{~m}$ and $4.8 \pm 0.75 \mathrm{~m}$, respectively). Comparatively, replicas at all three sites within Zealandia tended to be within one metre of vegetation, with little variation in vegetation distances within each site. Replicas at Matiu/Somes Island were less exposed than those on Mana Island, with replicas sitting 
within $~ 1.2$ metres of vegetation at the Northern Wharf and Southern Walkway sites. Replicas at Bunker Paddock had a greater distance to vegetation $(2.1 \pm 0.36 \mathrm{~m})$ than the other Matiu/Somes Island sites. The three Mana Island sites had large differences in vegetation distances, with replicas at Wētā Valley two-fold closer to vegetation $(1.25 \pm 0.11 \mathrm{~m})$ than at Shingle Point or Hole-in-rock Beach ( $3.5 \pm 0.18 \mathrm{~m}$ and $4.3 \pm 0.31 \mathrm{~m}$, respectively).

Nine lizard replicas were missing values for canopy cover, and therefore were not included in analyses or within Figure 3.8. I excluded eight of these values due to incorrect estimates made by the Hemispherical_2.0 software which could not be corrected, and the remaining value was excluded due to a missed canopy cover photo.

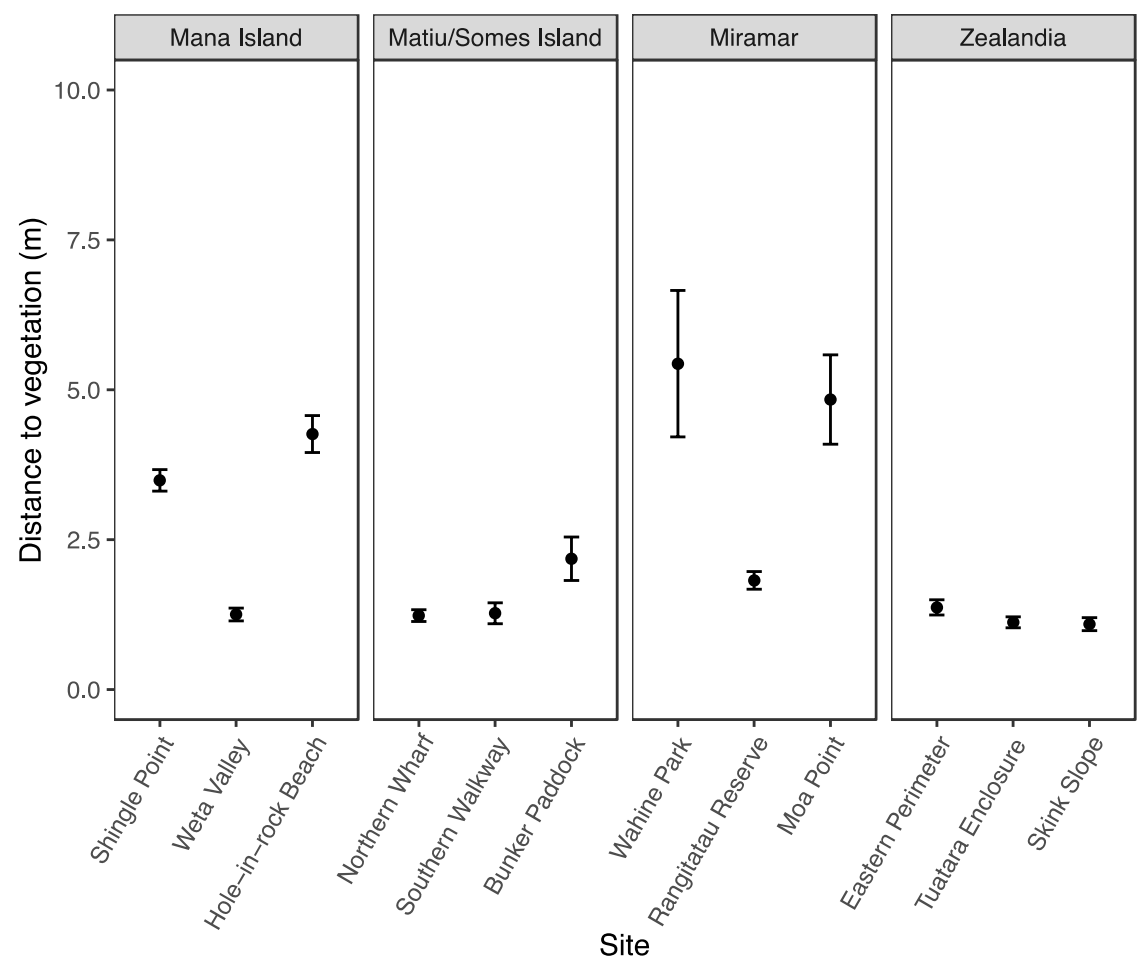

Figure 3.7: Mean distance in metres between lizard replicas and the nearest vegetation. Vegetation had to have a height of at least one metre. Error bars represent one standard error of the mean for each site.

Overall, replicas placed at sites within Zealandia had a higher average canopy cover than replicas at other sites $(20-75 \%$; Figure 3.8). This was followed by replicas at Wētā Valley, which showed a much higher mean canopy cover (64\%) in comparison to the other two Mana Island sites (both 0\%). Similarly, on Matiu/Somes Island, replicas placed at the Southern Walkway site had higher canopy cover values (29\%) than replicas placed at the Northern Wharf (1.8\%) and Bunker Paddock (3.6\%). Replicas placed at sites within Miramar had 
consistently low canopy cover values across all sites, with Wahine Park and Moa Point replicas having an average of 0\% canopy cover and replicas at Rangitatau Reserve experiencing a slightly higher mean canopy cover of $6 \%$.

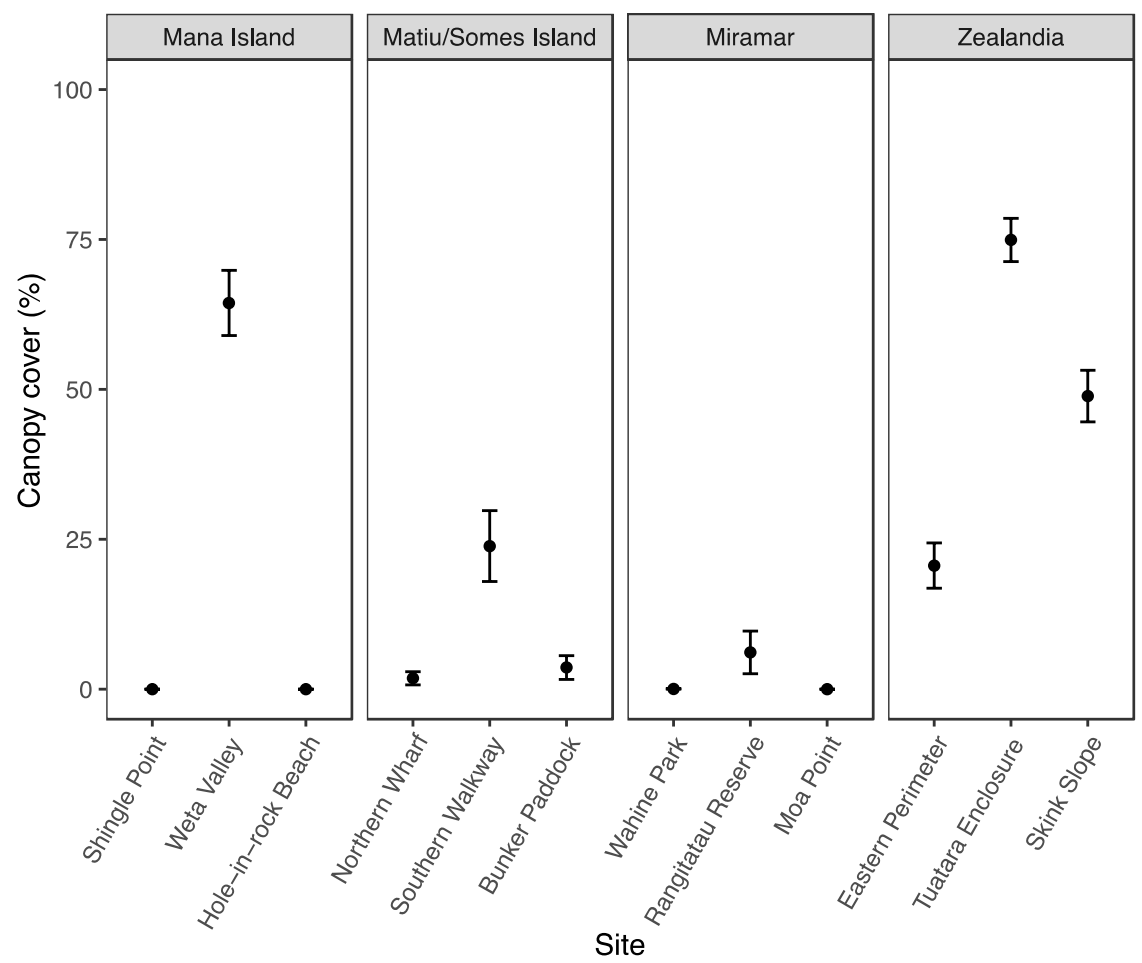

Figure 3.8: Mean canopy cover \% recorded at site of lizard replica deployment. Canopy cover calculated using Hemispherical_2.0. Error bars represent one standard error of the mean for each site.

\subsubsection{Identification of potential predators}

\subsubsection{Five-minute bird counts}

A total of 34 bird species were detected during five-minute bird counts across four locations in the Wellington region (Table 3.4). Twenty-seven species (79.4\%) were endemic or native, and seven species $(20.6 \%)$ were introduced (Table 3.4). A large variation in bird diversity was captured within bird counts across research locations, with 13 species found to be unique to individual sites. At each research location I encountered four to six introduced bird species. Four species were detected across all locations: the chaffinch (Fringilla coelebs), blackbird (Turdus merula), southern black-backed gull (Larus dominicanus dominicanus), and starling (Sturnus vulgaris). 
Table 3.4 - The thirty-four bird species encountered during the five-minute bird counts conducted for this study (January-May 2019). A total of 153 counts were taken across 12 bird count stations around four locations in the Wellington region. The binomial classification and status for each New Zealand species was gathered from Robertson et al. (2017). Status identifies species as either 'N' native or 'I' introduced to New Zealand. Location depicts the research locations where the species was encountered during this study: MA - Mana Island, MI - southern Miramar Peninsula, MS - Matiu/Somes Island, ZE - Zealandia Ecosanctuary. Species in bold have been identified as predators of New Zealand lizards by the literature (see Oliver 1955; Carroll 1966; Mander 1972; Crossland \& Freeman 1995; Bell 1996; Heather \& Robertson 1996; Thompson 2000; van Winkel 2008).

\begin{tabular}{|c|c|c|c|}
\hline Common name & Scientific name & Status & Location \\
\hline Australasian/ swamp harrier & Circus approximans & $\mathrm{N}$ & MA \\
\hline Bellbird (mainland) & Anthornis melanura melanura & $\mathrm{N}$ & MA, ZE \\
\hline Blackbird & Turdus merula & I & MA, MI, MS, ZE \\
\hline Canada goose & Branta canadensis & I & $\mathrm{ZE}$ \\
\hline Chaffinch & Fringilla coelebs & I & MA, MI, MS, ZE \\
\hline Dunnock/hedge sparrow & Prunella modularis & I & MI, MS \\
\hline Goldfinch & Carduelis carduelis & I & MA, MI \\
\hline Grey warbler & Gerygone igata & $\mathrm{N}$ & $\mathrm{ZE}$ \\
\hline Hihi/stitchbird & Notiomystis cincta & $\mathrm{N}$ & $\mathrm{ZE}$ \\
\hline House sparrow & Passer domesticus & I & MA, MI, ZE \\
\hline $\begin{array}{l}\text { Kererū/ New Zealand wood } \\
\text { pigeon }\end{array}$ & Hemiphaga novaeseelandiae & $\mathrm{N}$ & $\mathrm{ZE}$ \\
\hline Little shag & $\begin{array}{l}\text { Phalacrocorax melanoleucos } \\
\text { brevirostris }\end{array}$ & $\mathrm{N}$ & MI, MS \\
\hline Little black shag & Phalacrocorax sulcirostris & $\mathrm{N}$ & MI \\
\hline New Zealand sacred kingfisher & Todiramphus sanctus vagans & $\mathrm{N}$ & MA, MS \\
\hline North Island fantail & Rhipidura fuliginosa placabilis & $\mathrm{N}$ & MA, MS, ZE \\
\hline North Island kākā & $\begin{array}{l}\text { Nestor meridionalis } \\
\text { septentrionalis }\end{array}$ & $\mathrm{N}$ & $\mathrm{ZE}$ \\
\hline North Island robin & Petroica longipes & $\mathrm{N}$ & MA, ZE \\
\hline North Island saddleback & Philesturnus rufusater & $\mathrm{N}$ & $\mathrm{ZE}$ \\
\hline Paradise shelduck & Tadorna variegata & $\mathrm{N}$ & MA \\
\hline Pied shag & Phalacrocorax varius varius & $\mathrm{N}$ & MA, MI, ZE \\
\hline Pūkeko & Porphyrio melanotus melanotus & $\mathrm{N}$ & MA \\
\hline Red-billed gull & $\begin{array}{l}\text { Larus novaehollandiae } \\
\text { scopulinus }\end{array}$ & $\mathrm{N}$ & MA, MI, ZE \\
\hline
\end{tabular}




\begin{tabular}{|c|c|c|c|}
\hline Red-crowned kākāriki & $\begin{array}{l}\text { Cyanoramphus novaezelandiae } \\
\text { novaezelandiae }\end{array}$ & $\mathrm{N}$ & MS, ZE \\
\hline Reef heron & Egretta sacra sacra & $\mathrm{N}$ & MA \\
\hline Silvereye/waxeye & Zosterops lateralis lateralis & $\mathrm{N}$ & MI, MS, ZE \\
\hline Southern black-backed gull & Larus dominicanus dominicanus & $\mathrm{N}$ & MA, MI, MS, ZE \\
\hline Starling & Sturnus vulgaris & I & MA, MI, MS, ZE \\
\hline Tūī & $\begin{array}{l}\text { Prosthemadera novaeseelandiae } \\
\text { novaeseelandiae }\end{array}$ & $\mathrm{N}$ & MA, MI, ZE \\
\hline Variable oystercatcher & Haematopus unicolor & $\mathrm{N}$ & MA, MI \\
\hline Welcome swallow & Hirundo neoxena neoxena & $\mathrm{N}$ & MA, MI \\
\hline White-faced heron & Egretta novaehollandiae & $\mathrm{N}$ & MA \\
\hline White-fronted tern & Sterna striata striata & $\mathrm{N}$ & MA, MI, MS \\
\hline Whitehead & Mohoua albicilla & $\mathrm{N}$ & MA, ZE \\
\hline Yellow-crowned kākāriki & Cyanoramphus auriceps & $\mathrm{N}$ & MA \\
\hline
\end{tabular}

Mana Island had the highest number of species detected with 23 bird species identified across three 5-minute bird count stations (Figures 3.9 and 3.11). Mana Island had the highest presence of lizard predators, with nine detected across habitat sites. However, Mana Island also had the largest bird count sample size, with 55 bird counts undertaken across the three sites. Eighteen species (78.3\%) were endemic or native, and five species (21.7\%) were introduced (Table 3.4). As coastal sites, Shingle Point and Hole-in-rock Beach had a high presence and abundance of native seabirds. Southern black-backed gulls were detected across all 18 counts at both sites. Gulls were detected in high numbers at Shingle Point ( 10 birds per count) and Hole-in-rock Beach ( $~ 5$ birds per count). The presence of this species is likely due to the proximity of a breeding colony (> 20 individuals) located at Shingle Point beach (Pers. obs.). Red-billed gulls were present in $80 \%$ of counts at Shingle Point and $50 \%$ of counts at Hole-in-rock Beach, with an average of 6 individuals detected per count. Starlings were also present for most counts at both Shingle Point (17 of 18) and Hole-in-rock Beach (16 of 18) and were detected in high numbers with multiple flocks of $15+$ birds observed during bird counts (Pers. obs.). As both coastal sites were adjacent to forested habitat, there was also high presence of endemic forest bird species, however, these were all detected in relatively low numbers within counts $(<4$ individuals per species). Pied shags were present in $100 \%$ of the bird counts at Hole-in-rock Beach due to proximity of the site to a roosting area (Pers. obs.). Pūkeko were only detected during counts at the two coastal sites and were detected in less than a quarter of the counts 
conducted at each site. Pūkeko were only detected in low numbers during counts, with less than one bird detected per count on average. Pūkeko were also present at Wētā Valley but were only identified in photographs from the deployed motion-sensitive cameras. At Wētā Valley, starlings, southern black-backed gulls, and kingfishers were detected half the time, but all in low numbers (average of $<1$ bird per count). Blackbirds were also only detected in low numbers (average of $<1$ bird per count) and were only detected within the forested Wêtā Valley site.

Five-minute bird count stations on Matiu/Somes Island recorded 11 species, four of which are lizard predators (Figures 3.9 and 3.11). Seven species were endemic or native (63.6\%) and four species were introduced (36.4\%). Southern-black backed gulls had the highest encounter rate with a $100 \%$ presence across all three habitat sites but were only seen in high abundance at the Northern Wharf ( 16 birds per count). Additionally, an active southern black-backed gull nest site was present at Bunker Paddock (Pers. obs.). Red crowned kākāriki and silvereyes had a relatively high presence (> 70\% counts per site) across the island. Blackbirds were detected at all three sites, with the highest presence at Southern Walkway with fewer than 2 birds detected per count. Kingfishers had a low presence ( $<25 \%$ counts) across the Northern Wharf and Bunker Paddock sites. Although not included during five-minute bird counts, the New Zealand kingfisher was observed at the Southern Walkway site (Pers. obs.).

Southern Miramar Peninsula had the highest proportion of introduced species (6 of 16, 37.5\%; Table 3.4). Wahine Park had a higher proportion of introduced species, but I observed large flocks of goldfinches at Moa Point during counts (Pers. obs.). Like at Mana Island and Matiu/Somes Island, southern black-backed gulls were the most encountered coastal species with $100 \%$ presence across all three sites at Miramar (Figure 3.10). Gulls were detected in higher numbers at Wahine Park and Moa Point ( 10 birds per count) compared to Rangitatau Reserve ( 6 birds per count) (Figure 3.12). Additionally, Moa Point hosted an active nesting site for southern black-backed gulls (Pers. obs.). Red-billed gulls had a high presence across all sites (60 - 100\% of counts) but were detected in lower numbers at Rangitatau Reserve compared to the two coastal sites. There was a high presence of introduced species at Rangitatau Reserve, with starlings present during $100 \%$ of counts and house sparrows during $90 \%$ of counts. This site was located behind the Moa Point Dog Pound, so it is likely these species were attracted to anthropogenic waste. 
Zealandia Ecosanctuary was the second most speciose site, with encounters tending towards native and endemic species (73.7\%; 14 of 19 species) as expected at a mainland sanctuary (Table 3.4). The North Island kākā, North Island saddleback, and tūī all had a high presence (> 75\% of counts) across each of the three sites in the sanctuary and were detected in relatively high numbers ( $<4$ birds per count) compared to all other native species. The other native forest species had a high presence across all sites in the sanctuary but were detected in relatively low numbers $(<2$ birds per count). Overall, introduced species had a low presence within the sanctuary, but blackbirds were present at all three sites in low numbers (average of $<1$ bird per count). The highest presence for house sparrows was recorded at Skink Slope, likely because the site was overlooking Tūī Terrace - a lawn area used as a picnic-stop for visitors (Pers. obs.). Southern black-backed gulls were detected during counts at Zealandia, but individuals were only observed flying over the sanctuary. 

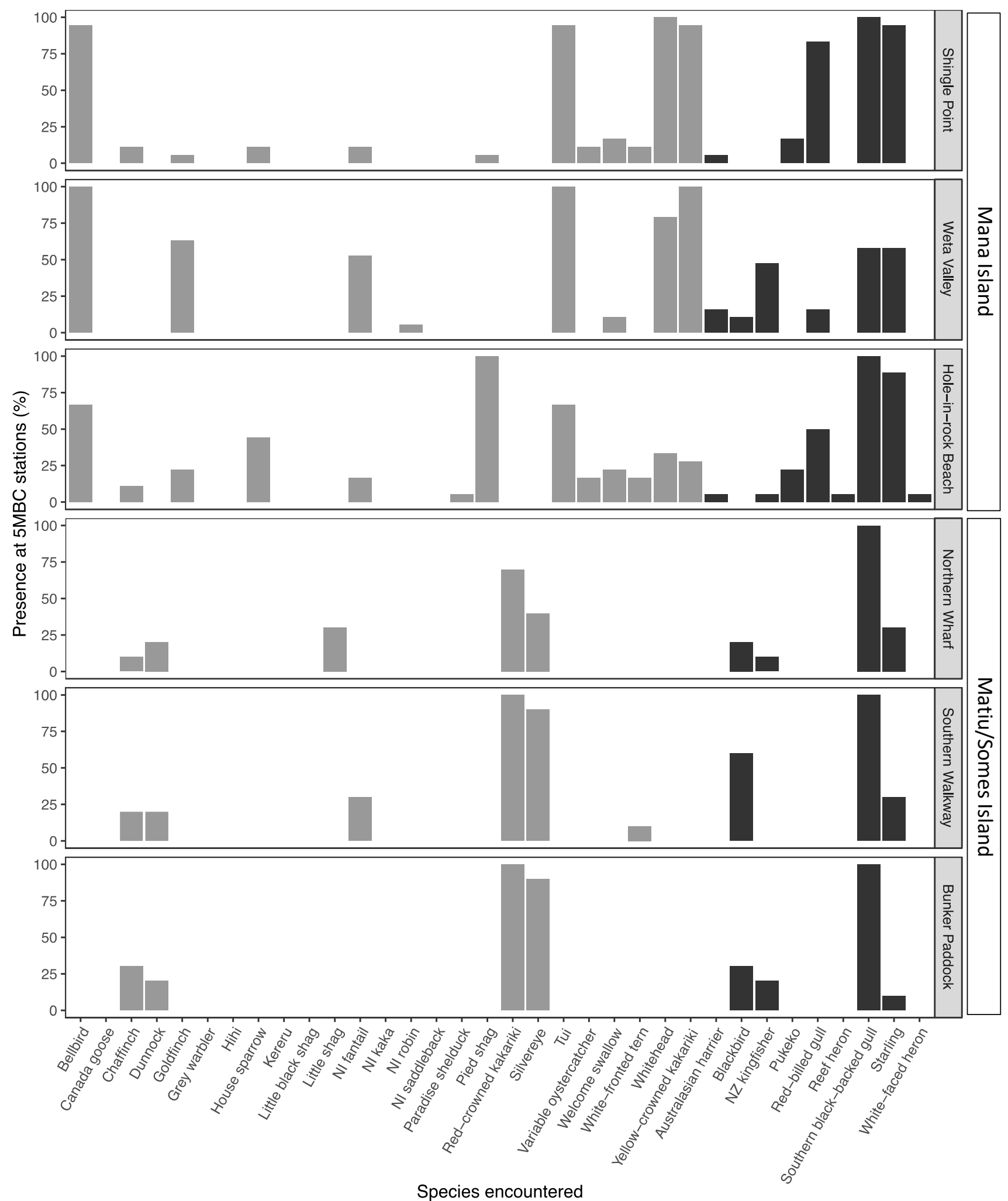

Figure 3.9: Relative presence (\%) of each bird species encountered on Mana Island and Matiu/Somes Islands during 5-minute bird counts. Species denoted by black bars are previously identified predators of New Zealand lizards. Five-minute bird counts were conducted across three bird count stations at each location. Mana Island: Shingle Point $(\mathrm{n}=18)$, Wētā Valley $(\mathrm{n}=19)$, Hole-in-rock Beach $(\mathrm{n}=18)$. Matiu/Somes Island: Northern Wharf $(\mathrm{n}=10)$, Southern Walkway $(\mathrm{n}=10)$, Bunker Paddock $(\mathrm{n}=10)$. 


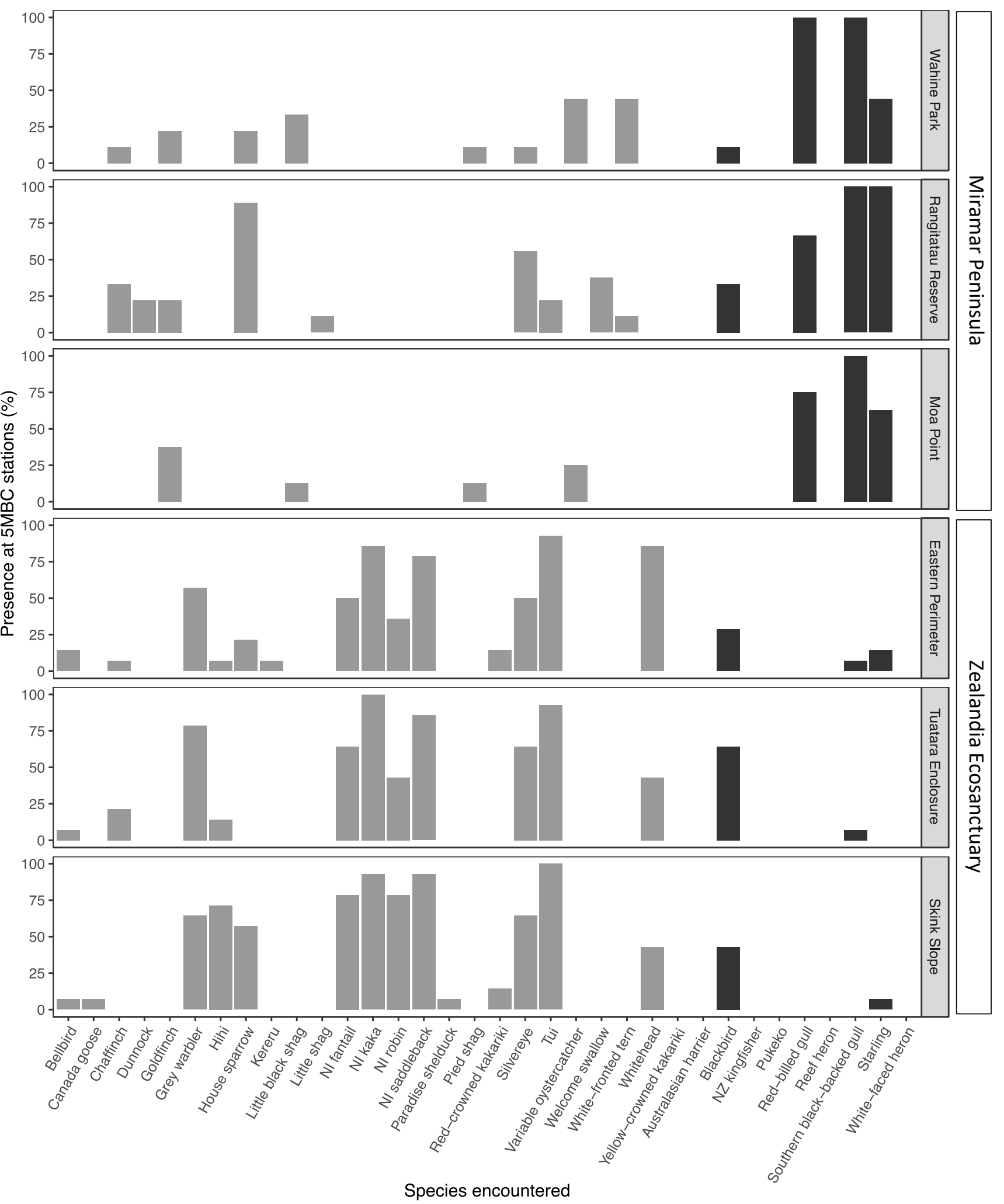

Figure 3.10: Relative presence (\%) of each bird species encountered on Mana Island and Matiu/Somes Islands during 5-minute bird counts. Species denoted by black bars are previously identified predators of New Zealand lizards. Five-minute bird counts were conducted across three bird count stations at each location. Miramar Peninsula: Wahine Park $(\mathrm{n}=9)$, Rangitatau Reserve $(\mathrm{n}=9)$, Moa Point $(\mathrm{n}=8)$. Zealandia Ecosanctuary: Eastern Perimeter $(\mathrm{n}=14)$, Tuatara Enclosure $(\mathrm{n}=14)$, Skink Slope $(\mathrm{n}=14)$. 

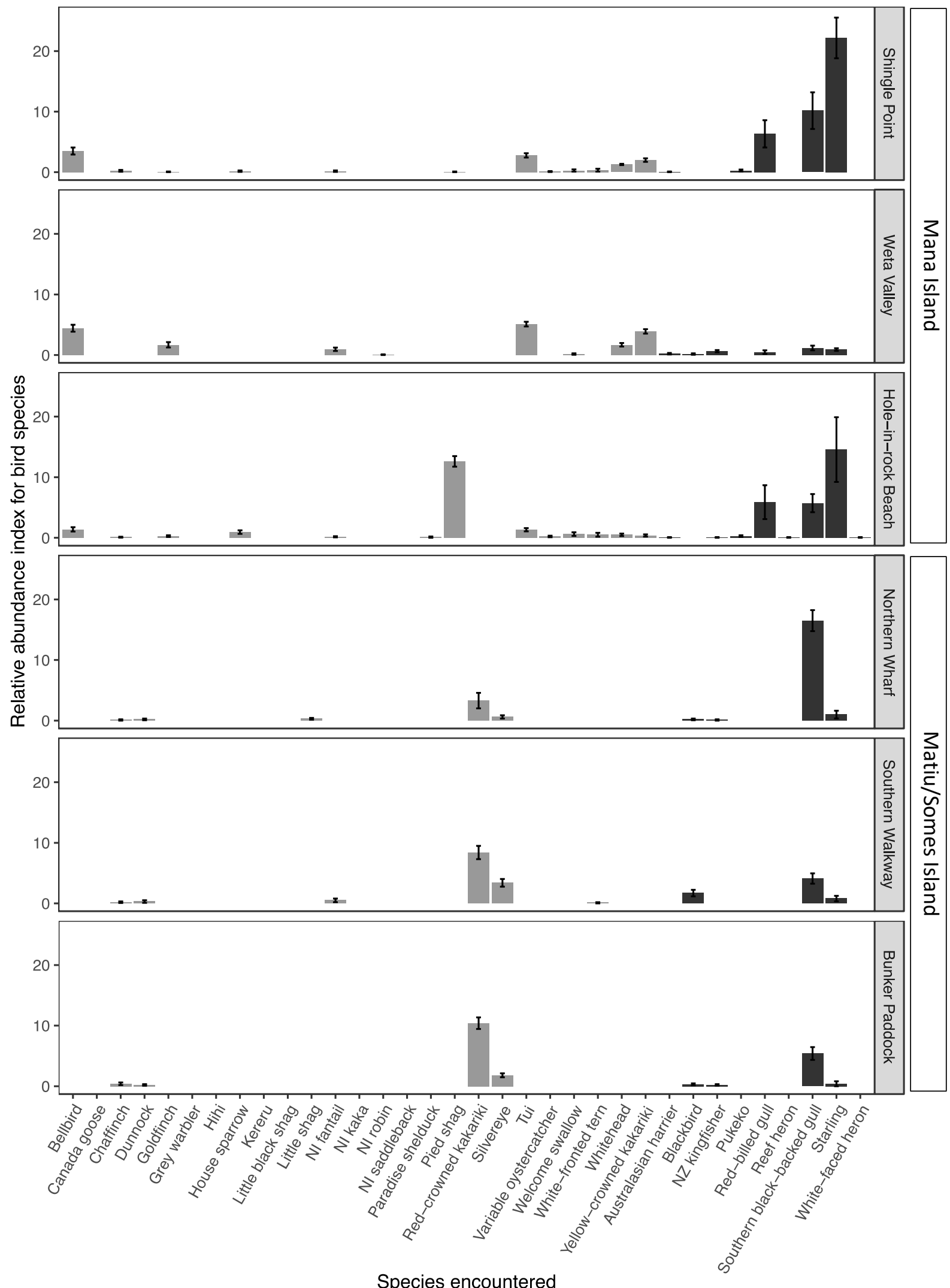

Species encountered

Figure 3.11: Relative abundance of birds encountered on Mana Island and Matiu/Somes Islands during 5 -minute bird counts. Relative abundance is the average number of birds detected per count. Error bars are one standard error of the mean. Species denoted by black bars are previously identified predators of New Zealand lizards. Mana Island: Shingle Point $(\mathrm{n}=18)$, Wētā Valley $(\mathrm{n}=19)$, Hole-in-rock Beach (n =18). Matiu/Somes Island: Northern Wharf $(\mathrm{n}=10)$, Southern Walkway $(\mathrm{n}=10)$, Bunker Paddock $(\mathrm{n}=$ $10)$. 


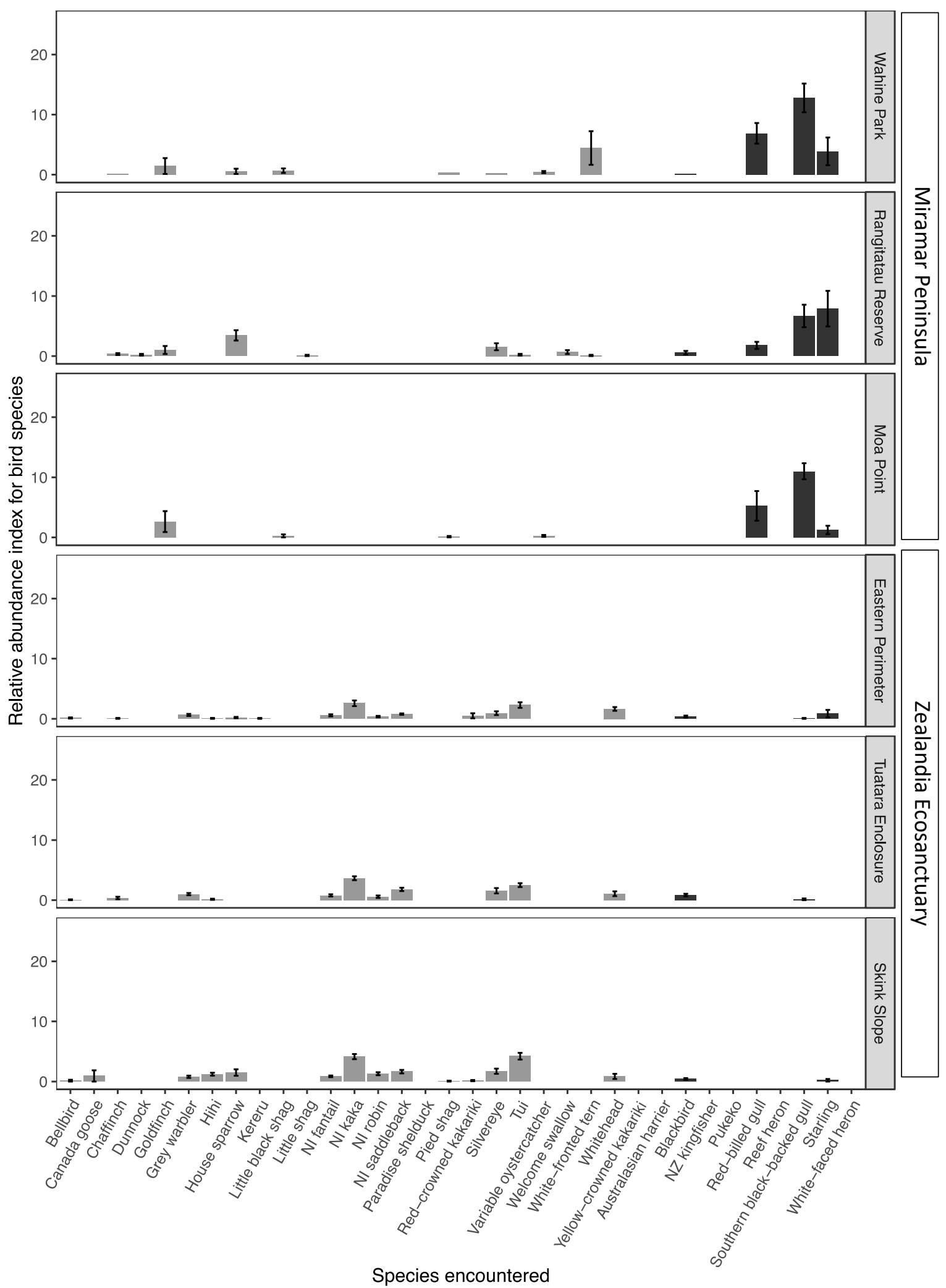

Figure 3.12: Relative abundance of birds encountered at Miramar and Zealandia during 5-minute bird counts. Relative abundance is the average number of birds detected per count. Error bars are one standard error of the mean. Species denoted by black bars are previously identified predators of New Zealand lizards. Miramar Peninsula: Wahine Park $(n=9)$, Rangitatau Reserve $(n=9)$, Moa Point $(n=8)$. Zealandia Ecosanctuary: Eastern Perimeter $(\mathrm{n}=14)$, Tuatara Enclosure $(\mathrm{n}=14)$, Skink Slope $(\mathrm{n}=14)$. 


\subsubsection{Motion-sensitive cameras}

Of the 153 predation events recorded for replicas 26 had cameras present. Using the photographs taken, I identified a total of 13 of these attacks to species level, with five events not detected by the camera and a further eight events unable to be confidently assigned to a species as photographs lacked evidence of direct contact by a bird (Table 3.5). All attacks recorded by the camera occurred between the hours of 7:03 and 19:56 NZST (Figure 3.13). No attacks were recorded during the night, likely reflecting the activity period of interacting birds. Alternatively, the motion-sensitive cameras were less sensitive to movement during darker periods. Pūkeko and southern black-backed gulls had the highest proportion of attacks caught on camera.

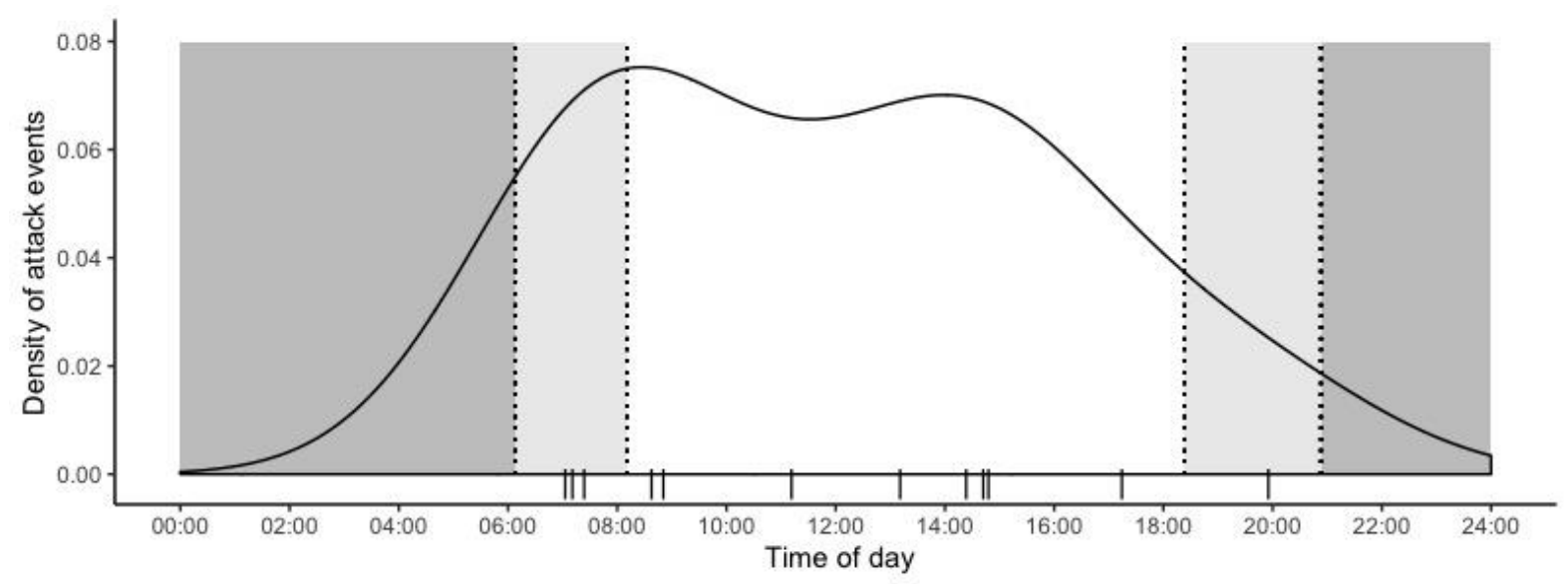

Figure 3.13: Probability density plot of attack events caught on motion-sensitive camera $(\mathrm{n}=$ 13). Time is plotted in NZST. Dotted lines represent the earliest and latest times for sunset and sunrise for Wellington during the 139-day research period (retrieved from timeanddate.com on 09/09/2020). Dashed lines below the graph indicate individual attack events.

\subsubsection{Peck identification}

The remaining 140 unidentified attacks were identified to species level using peck marks, if possible (Figure 3.14). During peck identification, one lizard replica was found to have pecks from both a pūkeko and a red-crowned kākāriki, although originally attributed (in the previous chapter) as a single attack from a large bird (Table 3.5). As such, 101 of the 141 attacks were identified to species level leaving only $26 \%$ of attacks unidentified. Pūkeko had the highest rate of interaction with replicas, with $31.8 \%$ of replica attacks attributed. Southern blackbacked gulls showed comparable rates of interaction with individuals responsible for $24.7 \%$ of attacks. Additionally, $13.5 \%$ attacks were attributed to blackbirds and starlings. 
I identified pecks by red-billed gulls by the thin $(\sim 2 \mathrm{~mm})$ ' $U$ ' shaped imprint of the upper and lower mandibles. In most circumstances the presence of the upper mandible ridgeline allowed differentiation from blackbird or starling pecks. The tip of the lower beak often left no imprint leaving a ' /' shaped mark instead. This was the case for both gull species, however, southern black-backed pecks could be discerned due to their much larger size.

I identified pecks from southern black-backed gulls as a small ' $\mathrm{V}$ ' shaped upper mandible with or without a midline ridge. The lower mandible was continuously left large $(\sim 5 \mathrm{~mm})$ ' $\mathrm{V}$ ' shaped lines within the clay, with the imprint lacking the beak tip. Southern black-backed gulls had larger and more ' $\mathrm{V}$ ' shaped pecks than the red-billed gull.

I identified pūkeko pecks through the distinct and omnipresent upper mandible ridgeline, and wide $(\sim 3 \mathrm{~mm})$ ' $\mathrm{V}$ ' shaped imprints from both the upper and lower mandible. The lower mandible showed widening of the beak edge from the tip to the back of the beak. Pūkeko imprints were shorter and wider than those left by southern black-backed gulls.

Kākāriki pecks were easily distinguished from other species as they consisted of a very curved and short $(<10 \mathrm{~mm})$ imprint consistent with the beak of a parrot. Peck imprints were not expected to differ across red-crowned and yellow-crowned kākāriki. However, the specific species could be assigned due to their limited presence at locations (i.e. red-crowned kākāriki at Matiu/Somes Island and Zealandia; yellow-crowned at Mana Island).

I was unable to find obvious differentiating factors between imprints left by blackbirds and starlings, so I grouped them. These species were identified by their very thin $(\sim 1.5 \mathrm{~mm})$ and small ' $U$ ' shaped imprints. The upper mandible ridge was not distinguishable within these species. 
Figure 3.14: Examples of the specific peck imprints left by bird species within this study. Each example shows imprints left by the upper and lower mandibles of each bird species. The upper mandible is usually identified by the midline ridge present down the centre of the peck imprint.
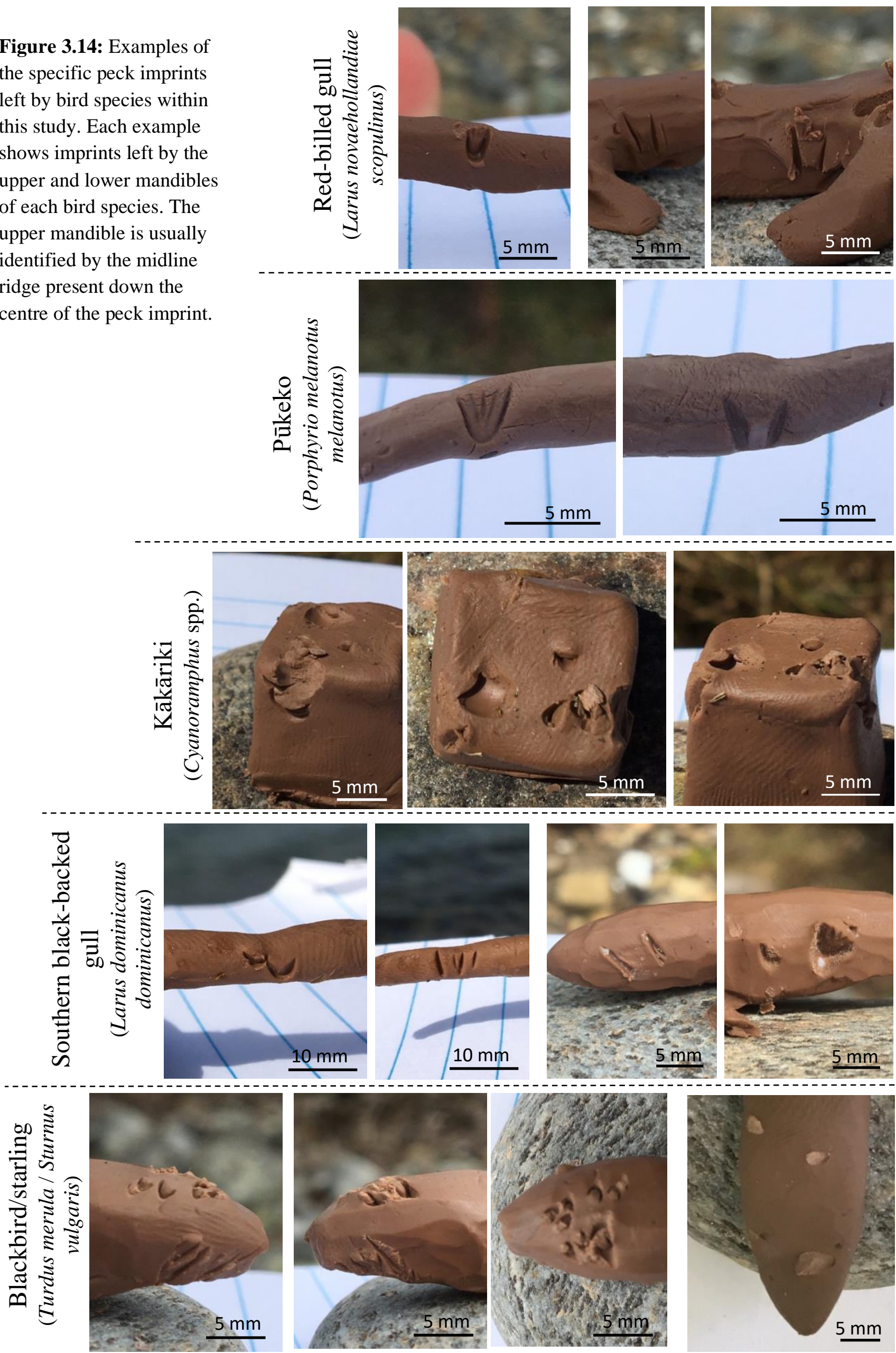
Table 3.5 - Summary of bird species identified pecking replicas. Data is pooled from all four research locations. Identifications were made using motion-triggered cameras or identifying species based on peck imprints left within the replica clay. Percentage refers to the proportion of attack events attributed to each bird species.

\begin{tabular}{|c|c|c|c|}
\hline \multirow[b]{2}{*}{ Species identified } & \multicolumn{2}{|c|}{ Identification method } & \multirow[b]{2}{*}{ Total } \\
\hline & Camera & Pecks & \\
\hline Pūkeko & 4 & $45^{*}$ & $49(31.82 \%)$ \\
\hline Southern black-backed gull & 5 & 33 & $38(24.68 \%)$ \\
\hline Blackbird/starling ${ }^{\wedge}$ & & 19 & $19(12.34 \%)$ \\
\hline Red-billed gull & 2 & 1 & $3(1.95 \%)$ \\
\hline Red-crowned kākāriki ${ }^{+}$ & & 2 & $2(1.3 \%)$ \\
\hline Yellow-crowned kākāriki ${ }^{+}$ & & $1 *$ & $1(0.65 \%)$ \\
\hline Blackbird & 1 & & $1(0.65 \%)$ \\
\hline Starling & 1 & & $1(0.65 \%)$ \\
\hline Unable to be identified & 127 & 40 & $40(25.97 \%)$ \\
\hline Not visible & 5 & & \\
\hline Unconfirmed & 8 & & \\
\hline Total & 153 & $141^{*}$ & $154(100.01 \%)^{\dagger}$ \\
\hline
\end{tabular}

* During peck mark assessment a predation event was identified as attacks from two species.

$\wedge$ Blackbirds and starlings were binned together due to uncertainty of species-specific peck identification.

${ }^{+}$Kākāriki pecks could be assigned to exact species based on replica location (red-crowned Matiu/Somes Island and Zealandia; yellow-crowned - Mana Island).

${ }^{\dagger}$ Percentage error due to rounding.

\subsubsection{What factors are influencing predation?}

\subsubsection{Environmental variables}

I analysed the relationship between the attack on lizard replicas and measures for habitat and weather characteristics for individual replicas (see Table 3.6). Although the generalised linear mixed-effects model showed no significant effects of environmental variables on the probability of replica attack by birds, the model was suggestive of several trends. The effect of lizard predators approached significance $(p=0.052)$, suggesting that increasing numbers of lizard predators present at site positively increased the attack probability of lizard replicas. Although the $p$-values were $>0.05$, the model suggests a negative effect of canopy cover $(p=$ 0.096), and daily rainfall ( $p=0.099)$ on attack probability of lizard replicas. 
Table 3.6 - Results of fixed effects in a generalised linear mixed-effects global model estimating the influence of environmental variables on the attack probability of replicas. Habitat site and individual replica identity were included as random effects.

\begin{tabular}{llll}
\hline Fixed effects & Estimate \pm SE & Z value & $\boldsymbol{p}$ value \\
\hline (Intercept) & $-2.421 \pm 0.254$ & -9.526 & $<2 \mathrm{e}-16$ \\
Canopy cover* & $-0.297 \pm 0.178$ & -1.664 & $\mathbf{0 . 0 9 6}$ \\
Max. temp.* & $0.162 \pm 0.1121$ & 1.445 & 0.149 \\
Daily rainfall & $-0.226 \pm 0.137$ & -1.650 & $\mathbf{0 . 0 9 9}$ \\
Max. gust* & $-0.128 \pm 0.153$ & -0.832 & 0.405 \\
No. of lizard predators* & $0.471 \pm 0.242$ & 1.946 & $\mathbf{0 . 0 5 2}$ \\
\hline
\end{tabular}

* Variables transformed using Z-standardisation

\subsection{Discussion}

Understanding predation pressures experienced by at-risk populations and how this differs both within and across locations provides context for the management of both predator and prey species. I quantified the rates of avian predation experienced by lizard-mimicking replicas at four sites within the Wellington region, and investigated the factors potentially affecting the predation of these replicas. I found that predation differed both within and among the four research locations. Overall, replicas experienced higher daily predation rates at island locations (10 - 25\% of replicas) than at mainland sites ( $<5 \%$ of replicas). However, one site within Miramar, Moa Point, experienced predation similar to that seen on offshore islands ( $20 \%$ of replicas). Although not significant predictors, attack rates experienced by lizard replicas were likely influenced by both the bird species at each site, and the habitat vegetation and daily weather which can influence bird foraging on individual replicas at each site.

All birds identified interacting with lizard replicas by motion-sensitive cameras were ground foraging species. This may directly reflect the foraging strategies of the free-ranging bird communities across sites, with ground foraging predators having relatively higher encounter rates with replicas than airborne predators. However, I cannot determine whether predation events from flying birds occurred through aerial attacks or from the ground. Other well-known predators of lizards, such as the New Zealand kingfisher, were not seen interacting with lizard replicas despite being present at island sites. It is possible that birds did not recognise the replicas as prey when flying over. As identification of lizard predators within this study was limited to species caught on motion-triggered cameras, it is recommended that future studies 
increase the number of cameras deployed in order to gain more confidence surrounding interacting species.

Attack rates on replicas were likely influenced by the number of lizard predator species at each site and the behaviour of those species. Seven species were identified pecking lizard replicas during this study. Despite only being present on Mana Island, pūkeko had the greatest number of interactions with replicas. Further, pūkeko were only present in a fraction of the bird counts conducted and, when detected, were only observed alone or in pairs (Pers. obs.). Therefore, it is likely the high number of attacks on replicas by pūkeko was the product of only a few individuals. In the case of lizard replicas, repeated attacks within a site by a species could indicate low levels of learning within a few individuals (i.e. not learning the unprofitability of pecking replicas), rather than a high population abundance (Mason et al. 2018). Although the artefact of replica use cannot be ruled out, pūkeko increase their take of vertebrate prey during breeding season to feed chicks (Craig 1974). Research on Mana Island took place during breeding season (January - February 2019) and the high attack rates on lizard replicas could be a result of this seasonal change in diet. There are limited accounts of lizard predation by pūkeko within the literature (Table 1.1). Pūkeko are primarily herbivores but are known to opportunistically prey on small animals, including birds and lizards (Carroll 1966; Craig 1974; Wishart 2008). Lizard remains found in the gizzards of dissected birds, constituted a miniscule proportion of their diet and as such they were believed to be of little consequence (Carroll 1966). However, the diet of insular pūkeko can be influenced by the quality and availability of food (Trewick 1996). The high abundance and density of lizards on Mana Island could offer increased opportunity for pūkeko to prey upon reptiles and become specialised predators. Regardless, the high attack rates on replicas within this study emphasises that even the presence of specific species at a site, rather than a high abundance, poses risk for lizard populations. In order to elucidate the predation pressure placed on lizards from the index imposed by lizard replica use, further research is needed to clarify the relative importance of lizards within pūkeko diet on Mana Island throughout the year.

Predation risk imposed on replicas can be the result of abundance and geographical range of lizard predators. Increased lizard predator abundance offers more opportunity for attack events on replicas to occur, but the rate of attack is likely determined by the foraging behaviour of species. Southern black-backed gulls have a high abundance within the Wellington region as they subsist off the anthropogenic waste generated by cities and landfills (Fordham \& Cormack 
1970; Miskelly 1999). Consequently, they were encountered at all four locations within this study, and in relatively high abundances across all sites, except Wētā Walley and all Zealandia sites. Southern black-backed gulls were responsible for $24.7 \%$ of identified attacks on lizard replicas. Although gulls were in high abundance, they contributed less predation risk to replicas than pūkeko, likely due to the differing foraging strategies employed by species. However, southern black-backed gulls are widespread along the New Zealand coastline and are considered a superabundant species (Galbraith et al. 2015; Bell \& Harborne 2018). Therefore, they have the ability to impose risk to lizard populations across a wide geographical range. No direct observation of lizard predation by southern black-backed gulls has been reported in New Zealand, but lizards have been recorded as part of their diet (Table 1.1). Although these general statements have not been corroborated by published observations, southern black-backed gulls could be important predators of lizards within New Zealand. Internationally, gulls of the Larus genus have been identified as predators of insular lizards (Castilla \& Labra 1998; PérezMellado et al. 2014; Piorno et al. 2016). One study found 47\% of attacks on replicas were attributed to L. cachinnans michaellis (Castilla \& Labra 1998). However, other studies have labelled lizard predation by this genus as opportunistic, or the result of exploratory behaviour (Pérez-Mellado et al. 2014; Piorno et al. 2016). Opportunistic foraging can still result in lizard fatality, and therefore have the same effect on a population as 'true' predation. The frequency of attacks on replicas by gulls could also be an artefact of breeding season. Castilla \& Labra (1998) found that replicas experienced increased predation intensity when placed closer to nests and further from vegetation. Within this study, southern black-backed gulls were observed actively nesting at Moa Point and Bunker Paddock, and both sites had daily attack rates over $20 \%$. As a result of replicas being placed in close proximity to breeding colonies, nesting gulls were likely responsible for the increased attack rates on replicas at these sites. Therefore, predation risk posed by southern black-backed gulls is likely a function of gull abundance and seasonal foraging activity.

Starlings and blackbirds were also recorded frequently interacting with replicas, contributing a total of $13.5 \%$ of identified attacks. Attacks were combined due to the uncertainty in species identification from peck marks. Both species are identified predators of New Zealand skinks, however, observations for these species are limited (Table 1.1). Although interaction rates with replicas were low, these species have the opportunity to be important predators of lizards within New Zealand. Blackbirds and starlings were present across all locations within this study, and are among the most frequently encountered introduced species in the Wellington region 
(McArthur et al. 2015). Starlings had a high presence at Mana Island (detected $57-94 \%$ of counts) and Miramar Peninsula (44 - 100\% counts), with high abundance indices at nonforested sites on Mana Island (average of 14-22 birds encountered per count). Starlings are gregarious birds and are known to travel wide distances in large flocks around Wellington (Flux \& Flux 1981). However, large flocks of twenty to fifty birds were only observed during counts at coastal sites on Mana Island (Pers. obs.). An increased abundance of predators offers increased predation risk for lizard replicas. However, this risk may only be seasonal as starlings exhibit seasonal local migration (Flux \& Flux 1981). Conversely, blackbirds had a high presence at sites at Zealandia Ecosanctuary (detected $28-64 \%$ of counts) and Matiu/Somes Island ( $20-60 \%$ counts) but had low abundance indices with fewer than two birds detected on average across counts. Blackbirds are territorial and often monogamous breeders, contributing towards their low abundance across sites (Heather \& Robertson 1996). Within my study locations they may offer reduced risk to lizards as they are found in low density. However, blackbirds are the most encountered species within Wellington green spaces, which is largely attributed to their population growth in response to mammalian predator control (McArthur et al. 2015). As urban-adapters, blackbirds and starlings thrive in anthropocentric environments, however, are not restricted to areas where humans are present (Mason et al. 2018). Although predation attempts on lizards by these predators may be occasional, these bird species are widespread and highly abundant, and therefore have ability to influence lizard populations across wide geographical scales. Although the potential impacts of each individual species cannot be separated, it is likely starlings offer higher predation risk to lizard populations due to their abundance across sites and gregarious nature.

Three other bird species were found interacting with replicas: red-billed gulls, red-crowned kākāriki, and yellow-crowned kākāriki. No formal record of lizard predation by red-billed gulls exists, however, lizards have been recorded as part of their diet within Oliver's (1955) field guide to New Zealand birds. Red-billed gulls were present in over $50 \%$ of the counts conducted at coastal sites at Mana Island and Miramar Peninsula, with an average of 5 - 6 birds detected per count. However, red-billed gulls were only responsible for $1.95 \%$ of the identified attacks on lizard replicas. It is likely that red-billed gulls occasionally prey on lizards, however, replica studies conducted across a wider variety of coastal sites and additional dietary analyses would be needed to confirm this. In comparison, no records of lizard consumption by kākāriki exists within the literature. The two kākāriki species were responsible for a total of $1.95 \%$ of attacks on replicas: red-crowned $(1.3 \%)$ and yellow-crowned (0.65\%). Kākāriki were present at three 
of four study locations but were not detected often at Zealandia sites ( $<14.28 \%$ counts). Kākāriki were detected regularly during counts on Mana Island (27 - 100\% of site counts) and Matiu/Somes Island (70 - 100\% of site counts). The highest abundance index recorded was on Matiu/Somes Island with an average of 10 red-crowned kākāriki encountered per count at Bunker Paddock. Even if kākāriki were only occasional lizard predators, with the large presence and moderate abundance we would expect higher interaction rates with replicas. As such, the low level of interaction with lizard replicas within this study and the lack of previous predatory observations indicates replica interactions by these species may be the result of inquisitive, rather than predatory, behaviour.

Although not significant predictors, results from this study suggest that daily rainfall and increasing canopy cover negatively influences the probability of avian attack on lizard replicas. Replicas were continuously exposed to predators including across periods where the lizard prey they mimic may be inactive and not available to predators i.e. during rainfall, cloud cover, and hours of darkness. Therefore, it is reasonable to assume that the negative influence of rainfall on attack probability is a reflection of bird activity during rainy days. Birds often reduce their activity levels during rainy periods, and rainfall itself can reduce the efficiency of bird foraging by increasing search time and decreasing the likelihood of prey detection (Kennedy 1970; Horikoshi et al. 2017). It is possible birds within this study experienced reduced foraging efficiency and spent less time foraging during rainy periods, resulting in fewer attacks on replicas. These results may not be biologically relevant in terms of predation risk experienced by New Zealand's reptile fauna, as ectotherms, lizards may not usually be available to predators during rainy or cold conditions.

Results from this study showed a trend in which increasing canopy cover decreased the probability of avian attack on individual replicas. One possible explanation is that canopy cover reduced the visibility of replicas to foraging birds. Although the majority of lizard predators identified were ground-based foragers the canopy-cover measurements used within this study did not discriminate across canopy levels (e.g. grasses, shrubs, trees). Therefore, it is possible that replicas with values of increasing canopy cover were less visible to both aerial and groundforaging birds (Shepard 2007; Mason et al. 2018). Additionally, the presence of vegetation surrounding lizard replicas can decrease the foraging efficiency of predators, due to difficulty moving within an environment and the increased time spent searching (Seymoure et al. 2018). However, the effect of vegetative cover on the predation risk imposed by birds varies across 
studies (see Lemessa et al. 2015). Within this study, Zealandia Ecosanctuary had the lowest daily attack rates on replicas and the highest values for canopy cover. It is likely that birds at Zealandia required increased search time due to the increased levels of vegetation reducing the detectability of lizard replicas within the environment. However, the reduced attack rates on replicas at high canopy cover sites could also be a function of the of the bird species using these habitats. Lizards present within heavily vegetated areas, such as forests, are unlikely to receive predation risk from high impact species such as gulls, pūkeko, and starlings which prefer opencountry and coastal areas. The lack, or low abundance, of these species may explain reduced attack rates on lizard replicas at heavily vegetated areas such as Wētā Valley and Zealandia. Therefore, the influence of canopy cover on predation risk experienced by replicas is likely compounded by the species present within these environments. Further, the background of lizard replicas can also influence their detectability within the environment (Baling 2017). Although lizard replicas within this experiment used a standardised background, the environment surrounding replicas and their associated rocks also likely influenced attack rates. However, further research needs to be conducted to understand the influence of differing vegetation structures and background on the detectability of lizard replicas within an environment.

Small lizard populations are most at risk from the negative effects of predation by birds (Baling et al. 2013). Within this study, between $0-25 \%$ of lizard replicas were attacked daily across sites, with the highest predation rates recorded at sites on Mana Island and Matiu/Somes Island. Although, this study did not investigate the direct impacts of predation pressure exerted by birds on lizard populations it provides evidence suggesting that even opportunistic foraging by birds can result in high prey takes. New Zealand has a large proportion of translocated, reintroduced, and remnant lizard populations, many of which are isolated to offshore islands and ecosanctuaries (Towns \& Ferreira 2001; Sherley et al. 2010; Baling et al. 2013; Romijn \& Hartley 2016). Translocations involve a founder population with limited size, often below 50 individuals (reviewed in Sherley et al. 2010). For example, recent translocations of the Wellington green gecko, Naultinus punctatus, to Mana Island in 2018 and 2020 have involved fewer than 20 individuals (Pers. obs.). Loss of an individual from these limited populations directly reduces the effective population size and future productivity of the population (Caughley 1994). Additionally, reducing the population size further will leave populations more at risk to stochastic events (Caughley 1994). As K-selected species New Zealand's lizards are unable to recover quickly from population-reducing events, as low rates of reproduction 
and long gestational periods does not allow for fast population growth within vulnerable populations (Cree 1994; Towns \& Ferreira 2001).

Predation on lizard replicas also provides implications for other conservation-managed species inhabiting the same areas. Matiu/Somes Island and Zealandia Ecosanctuary are home to translocated populations of tuatara (Sphenodon punctatus) and the Cook Strait giant wētā (Deinacrida rugosa) (McKenzie 2007; Sherley et al. 2010; Watts et al. 2017). Additionally, a burgeoning population of giant wêtā exists on Mana Island (Sherley 1998). However, little is known about the impact of predation by birds on tuatara, and like lizards, the majority of published records are anecdotal (Cree 2014). Additionally, pūkeko have been recorded preying on giant wētā at Mana Island, however, the prey take by this species has not been quantified (Trewick 1996). Predators that consume lizards are also likely to consume tuatara and wētā if given the opportunity (Thompson 2000). As such, lizard replicas could also provide information towards the predation pressures exerted by ground-foraging birds on these terrestrial species.

As predation pressure on different species within a community can differ, it is important to understand the relative predation risk experienced by species with differing niches. The continual deployment of lizard replicas within this study allowed predation risk to be representative of the wide range of activity phases exhibited by New Zealand's endemic geckos and skinks (Hare et al. 2016). However, the replicas used were skink-mimicking and the majority of skink species within New Zealand exhibit diurnal activity and terrestrial habitat use. The few replica attacks that were caught on camera were all during daylight hours, and no nocturnal predators were identified preying replicas. Comparatively, New Zealand geckos tend to be nocturnal and exhibit a mixture of arboreal and terrestrial habitat use (Hare et al. 2016). It is likely that both habitat use and the activity phase of lizards influences their predation risk by birds. For example, the majority of observations of lizard predation by morepork (Ninox novaeseelandiae novaeseelandiae), a nocturnal predator, record consumption of geckos (see Table 1.1; Cree \& Hare 2016). Further, the survival rates of the arboreal diurnal jewelled gecko, Naultinus gemmeus, did not significantly differ across bird exclusion and inclusion zones (Schneyer 2001). Predation risk experienced is likely to alter across temporal and spatial niches, as lizard species are exposed to different predators. Therefore, the predation risk experienced by New Zealand geckos may differ to rates recorded within this study. Further 
research is needed to understand how avian predation risk alters across terrestrial and arboreal lizard species, and diurnal and nocturnal species.

In conclusion, the predation risk experienced by lizard replicas differed greatly both within and among Wellington sites and was likely the result of a differing abundance and presence of bird species. All species identified interacting with lizard-mimicking replicas were exploratory ground-foraging species, which may be an artefact of the innate foraging behaviour exhibited by those species. However, previous research has stated the need to explore threats imposed by opportunistic ground-foraging species (Towns 1999; Gardner-Gee et al. 2007; van Winkel 2008). Replicas can be used successfully to provide an index for predation by ground-foraging birds on terrestrial lizards. Beak marks were able to be identified to species level in most cases, however, this was reliant on information from motion-sensitive cameras. Therefore, increasing the number of cameras used in future replica research is important for the identification of predatory species and their possible impacts on New Zealand lizard populations. Single bird species were identified as drivers of predation risk due to their foraging behaviour or general abundance. Pūkeko had the highest rates of replica interaction despite only being detected in low numbers at one location. Conversely, southern black-backed gulls were present at nearly every location and provided a moderate predation risk to lizard replicas. The impact of bird species on lizard populations is also likely influenced by breeding season due to increased prey takes and protein requirements (O'Donnell \& Hoare 2009). However, further work to understand the seasonal influence on predation by birds and the relative importance of lizard prey during this time. This study also found that the foraging efficiency of lizard predators was influenced by both daily rainfall and the vegetation present at each site. Lizards are more likely to be at risk from predation in open sites with little to no canopy cover. 
CHAPTER 3: FACTORS INFLUENCING LIZARD PREDATION 


\section{Chapter 4: General summary and implications}

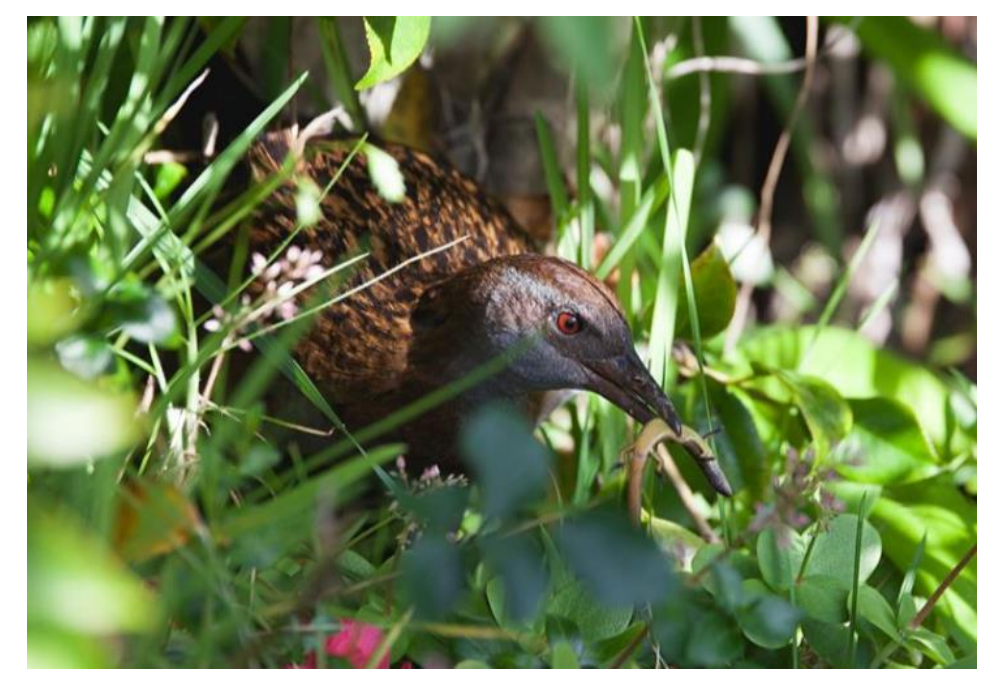

North Island weka (Gallirallus gallirallus greyi) with an unidentified skink (Oligosoma sp.) in its beak in Russell, Bay of Islands.

Photographed and approved for use by Lanson Fraser.

\subsection{Introduction}

Native predators have been overlooked in New Zealand ecosystems (van Winkel \& Ji 2012). The introduction of predatory mammals 700 years ago resulted in declines of all major terrestrial groups (i.e. birds [Bell et al. 2016], invertebrates [Watts et al. 2011], mammals [Pryde et al. 2005], and reptiles [Towns \& Daugherty 1994]); the impacts of introduced mammals have been well-documented within the literature. Even though New Zealand is recognised as a world leader in mammal eradication, we have limited knowledge of the role avian and reptilian predators play in our mammal-free ecosystems (Watts et al. 2014; Hitchmough et al. 2016a; Russell \& Broome 2016). It is important to understand the risks these predators pose to prey species in order to successfully manage and conserve populations in systems without mammals.

For a temperate country, New Zealand has a highly diverse yet vulnerable lizard fauna with $87 \%$ of the $100+$ species classified as 'At Risk' or 'Threatened' by the New Zealand Threat Classification System (Hitchmough et al. 2015). At least twenty-two native and nine introduced 
bird species prey on lizards within New Zealand (Table 1.1). However, few studies have directly investigated the interactions between birds and lizards, with the majority of evidence gathered from anecdotal observations (Table1.1). Despite the knowledge that episodic bouts of predation are likely to cause declines in vulnerable lizard populations, no studies within New Zealand have attempted to quantify avian predation rates on endemic lizard populations (Atkinson 1990; Reardon et al. 2012).

I investigated the predatory effect of birds on lizard populations by evaluating indices of predation using 3D printed lizard replicas. I aimed to:

- determine if clay models are recognised by birds as prey items;

- determine which species are preying on lizard models, and to what extent;

- evaluate how vegetation and weather factors influence predation.

\subsection{Overview of findings by chapter}

\subsubsection{Chapter 2: Assessing the use of lizard-mimicking replicas to quantify avian predation on lizards in New Zealand}

Birds are known predators of New Zealand lizards, but we have no standardised method to assess avian predation pressure exerted on lizard fauna. I deployed lizard-mimicking replicas across four Wellington sites to see if clay models can be used as an effective tool for indexing bird predation on lizards.

Clay models successfully recorded interaction marks from multiple bird species. Birds tended to find and attack clay models during their first day of exposure. Therefore, birds were out actively foraging across sites and their interactions with clay models were not limited by neophobic behaviour. Additionally, the majority of clay models experienced only one day of bird predation although they were exposed for a maximum of four days. It is likely that birds were not actively foraging in the same area across consecutive days or that birds recognised the unprofitability of attacking replicas. Attack frequency on clay models was high (> 30\%), but lizard-mimicking replicas were attacked at the same frequency as control novel objects. A similar probability of attack shows that birds were likely not recognising replicas as prey items and were actively exploring all objects within their range. 
Birds preferentially attacked the head of lizard replicas, over other larger regions of the body. Direct attacks on the head of prey-mimicking replicas are considered a realistic predatory response. This result contradicts the earlier statement that birds were not recognising lizard replicas as prey. As replicas are left exposed for continuous periods it is unclear whether attacks to the head were the first, original target for birds. Therefore, I cannot confidently state that replicas are recognised and interacted with by birds as prey items.

Lizard replicas experienced a high frequency of attacks from large and medium birds. This reflects what we know about potential predators identified from previous literature (e.g. pūkeko Porphyrio melanotus melanotus [van Winkel 2008], New Zealand falcon Falco novaeseelandiae [Kross et al. 2013], starling Sturnus vulgaris [Thompson 2000]; see Table 1.1). Control items experienced a wider array of attacks from differing bird size classes which would be expected from exploratory behaviour from free-ranging bird communities.

I found contradicting evidence towards lizard-mimicking replicas being appropriate models to assess lizard predation by birds. Interactions with lizard-mimicking replicas cannot be confirmed as true predation attempts. However, opportunistic attacks from birds could still result in lizard fatality. Therefore, the use of clay models still allows researchers to quantify interactions of actively foraging birds with lizard populations.

\subsubsection{Chapter 3: Habitat factors influencing the predation risk to lizards by birds in Wellington, New Zealand}

It is important to understand how predation risk varies across differing environments in order to avoid negative conservation outcomes when managing vulnerable populations (Saunders et al. 2018). The predation pressure experienced by lizard populations differed dramatically both within and among the four Wellington research locations. Overall, replicas experienced higher daily interaction rates at island locations (10 - 25\% replicas) than sites located on the mainland $(<5 \%)$, with the exception of Moa Point in Miramar (> 20\%). Although not significant predictors, attack rates on replicas were likely influenced by the presence of lizard predators at each site, canopy cover, and daily rainfall. 
Bird species were identified from beak imprints left in the clay of replicas. Motion-sensitive cameras allowed species identity to be assigned confidently to peck marks. For attacks not caught on camera, there was increased uncertainty identifying peck marks left by medium and small birds due to the lack of distinguishing beak features. All birds identified interacting with lizard replicas were ground-foraging species. This likely reflects the foraging strategies of the free-ranging bird communities across sites, with ground foraging predators more likely to encounter lizard replicas than airborne predators.

Five of the seven species found interacting with lizard-mimicking replicas were previously identified predators of New Zealand lizards. Although recognised as occasional lizard predators through anecdotal records, pūkeko and southern black-backed gulls (Larus dominicanus dominicanus) were identified as frequent predators of lizard replicas within this study. Attack rates on replicas were likely influenced by the foraging behaviour of bird species. Pūkeko were only present at one research location, and only detected in low numbers, but were responsible for a third of replica attacks. Predation risk can also be the result of an increased abundance and geographical range of lizard predators. Southern black-backed gulls were active at three of four locations and were responsible for $25 \%$ of replica attacks. Additionally, the frequency of attacks on replicas by pūkeko and gulls could be an artefact of breeding season as increased prey takes were recorded within active nesting areas or by individuals during breeding season. Blackbirds (Turdus merula) and starlings were jointly responsible for $13.5 \%$ of interactions with replicas. Although predation attempts on lizard replicas were occasional, blackbirds and starlings are widespread and highly abundant species, as a result they have ability to influence lizard populations across wide geographical scales. Very low levels of interaction $(<2 \%$ replicas) were recorded for three other bird species. Red-billed gulls $(L$. novaehollandiae scopulinus) were present at two locations, and were responsible for three attacks on replicas. The low level of replica interaction from the two kākāriki species (Cyanoramphus spp.), and lack of lizard predation history, indicates replica attacks were likely the result of inquisitive behaviour. Although sample sizes were small, every record of interaction increased knowledge in a field where information is scarce.

Although not significant predictors, increasing canopy cover and daily rainfall negatively influenced the probability of avian attack on individual replicas. Rainfall across sites likely reduced the time birds spent foraging, or reduced their foraging efficiency (Kennedy 1970; Horikoshi et al. 2017). However, this may not be biologically relevant as lizard species may 
not be available to predators during adverse weather conditions (Rößler et al. 2018). Increasing canopy cover above replicas likely reduced their visibility to both airborne and ground-foraging birds (Shepard 2007; Mason et al. 2018). Increased vegetation at sites can increase the foraging time of predators due to difficulty of movement and increased search time (Seymoure et al. 2018).

I found that predation risk on New Zealand lizards can differ drastically across and within sites, and this is likely due to the presence or absence of specific predatory bird species. Specific bird species can drive the predation risk experienced by lizard populations due to the efficient foraging behaviour of individuals, or the general abundance of the species at a site.

\subsection{Discussion}

Within New Zealand, the success of conservation projects is often measured through the population response of bird species (Nelson et al. 2016). With this comes an assumption that mammal predator control techniques that aid bird populations will also result in the increase of other vulnerable native species (Hitchmough et al. 2016a). The response of less charismatic and/or more cryptic species, such as reptiles and invertebrates, to the same mammal predator regimes can be overlooked (e.g. Watts et al. 2014; Dumont 2015). This biased view has the opportunity to result in negative outcomes for lizard populations (Hitchmough et al. 2016a). Further investigating the threats experienced by lizard populations, as an already overlooked and vulnerable fauna, will help managers identify and mitigate risks.

Successful conservation management begins with understanding what threats species face (Caughley 1994). Successful conservation of New Zealand's lizard fauna following the control of mammalian predators requires an understanding of the threats imposed by native predators (Towns 1999; Gardner-Gee et al. 2007; van Winkel 2008). This is particularly important in places where bird populations have expanded and where their effects on lizard populations may be amplified. Rebounding bird populations may affect the potential for lizard populations to similarly rebound from small population remnants that hung on through mammal presence.

From my results, I will discuss five influences on lizard predation by birds: assemblage of bird predators; presence of specific bird predators; search behaviour; seasonality; and interactions with habitat. Zealandia Ecosanctuary is well known for its efforts to reintroduce native forest 
species to the Wellington region, and is a refuge for a high diversity and abundance of bird species, but also has recovering remnant lizard populations (Miskelly 2018). In contrast to the population success of most bird populations following mammal control, lizard populations in Zealandia are showing only limited signs of increasing population growth (e.g. ornate skink Oligosoma ornatum; Romijn 2013). However, low incidence of bird interactions with replicas do not explain slowed population growth and small population numbers in ornate skinks. Lizard-mimicking replicas at this location experienced the lowest interaction rates by bird predators of all locations in the study, with fewer than $5 \%$ of replicas attacked daily. This result could potentially be interpreted to be a consequence of the assemblage of birds in Zealandia. Within New Zealand, very few forest birds are known lizard predators (Table 1.1). Most native lizard predators are species that primarily occur in coastal, wetland, or open-country areas (e.g. swamp harrier Circus approximans; black-fronted tern; white-faced heron Egretta novaehollandiae; New Zealand kingfisher (Todiramphus sanctus vagans); pūkeko; Table 1.1). In addition, none of the known native lizard predators were detected within the sanctuary during this research, either during bird observations or through interactions with replicas, even though at least four species are known to be present in low numbers: New Zealand kingfisher, swamp harrier, New Zealand falcon, South Island takahē (Porphyrio hochstetteri) (Miskelly 2018). Non-native lizard predators, blackbirds and starlings, were detected frequently in the sanctuary in my study, and have been previously recorded in high numbers by Miskelly (2018). Blackbirds, as a forest-inhabiting species, were detected more frequently in the sanctuary than starlings, and starlings were detected only at sites close to open grassy spaces and along the sanctuary edge. However, my results from locations other than Zealandia indicate predation risk may be related to the presence of particular, high impact species, rather than a general presence of predatory birds. Two bird species were identified as offering increased risk to lizard populations: southern black-backed gulls and pūkeko. Rates of predation on replicas were relatively high in places where southern black-backed gulls were present (Moa Point and Bunker Paddock). Pūkeko were more isolated within the Wellington region, but where they were detected (Mana Island), they had a high impact on replicas at all sites. Pūkeko numbers are expected to decline on Mana Island with forest regrowth, but even very few individuals have the ability to impose predation pressures on lizard populations (Miskelly 1999).

The impacts imposed by birds on lizard populations can be complicated by their innate foraging behaviour. Results from this study support the idea that ground-foraging birds are a threat to lizards due to their opportunistic feeding behaviour (Towns 1999; Gardner-Gee et al. 2007; 
van Winkel 2008). Ground-foragers, as opposed to flying predators, have an increased likelihood of chancing upon semi-fossorial or terrestrial lizards when combing wide areas for food sources. Additionally, the presence of vegetation should not greatly impede foraging by ground-based birds as opposed to the immediate reduction in visibility for flying predators. The risk experienced by lizard species will be influenced by their use of habitat. Skink (Scincidae) species may experience increased risk due to the prevalence of terrestrial habitat use across species, but two-thirds of gecko species have also been identified as, at least, partial users of terrestrial habitat.

Risk experienced by lizard populations can be influenced by seasonality. Attack rates on lizard replicas were high at southern-black backed gull breeding sites, and pūkeko were identified foraging with young. Birds are known to consume vertebrate prey during breeding season in order to increase their protein intake to meet rising energetic demands (O’Donnell \& Hoare 2009). For example, a single starling was observed catching three Oligosoma infrapunctatum to feed to chicks on Stephens Island in one hour (Thompson 2000). The feeding of lizards to young has been documented for many bird species in New Zealand: black-fronted tern Chlidonias albostriatus (O’Donnell \& Hoare 2009), North Island fernbird Bowdleria punctata vealeae (Ball \& Parrish 2005), starling (Thompson 2000), morepork Ninox novaeseelandiae novaeseelandiae (Ramsay \& Watt 1971), and New Zealand kingfisher (Moon 1986). It is likely that predation risk experienced by lizard populations fluctuates throughout the year. Therefore, it might be that starlings in Zealandia, for example, offer increased predation risk while they are nesting and as a result the possible impact of these species may not have been recorded within this study. Research should be conducted to understand the relative risk breeding season imposes on lizard populations, especially when they are located within close proximity to breeding colonies.

Predation rates imposed by birds could also be an artefact of prey availability within habitats. In the absence of mammalian predators, lizards can reach extremely high densities on offshore islands (Towns 1996; Habgood 2003). High prey densities offer increased predation potential for birds by reducing search time during foraging (Draulans 1987). For example, lizards are a large component of kingfisher diet on Tiritiri Matangi Island where lizard densities can exceed 4000 individuals per hectare (Habgood 2003; van Winkel \& Ji 2012). Daily predation rates for lizard replicas were higher on offshore islands than sites on the mainland. Although this could be a result of lizard predators, i.e. open-country or coastal bird species, being well represented 
within the insular avifauna (Bellingham et al. 2010), both Mana Island and Matiu/Somes Islands have high densities of lizards (Miskelly 1999). The high lizard density could offer increased opportunity for birds to prey upon lizards and become specialised predators.

Lizard replicas experienced high predation rates, with an average of $0-25 \%$ of replicas attacked daily across sites. Although attack rates were frequent, the use of lizard replicas as a predation index does not account for the behaviour of prey in response to predators, and how this plays a role in predation risk. New Zealand's lizards exhibit adaptations that reduce their susceptibility to predation by birds, such as crypsis, caudal autotomy, and escape or evasion (Hare \& Miller 2010; Hare et al. 2016). As a result, predation indices supplied by replicas are likely to overestimate predation rates as static models do not exhibit antipredator defences (Webb \& Whiting 2005). Additionally, the activity phase of lizards is likely to alter which predators are available to interact with species and therefore alter the predation risk experienced. Within this research, lizard replicas were left exposed for 24-hour periods. It is likely that the predation risk for crepuscular species, such as the ornate skink present in Zealandia, and nocturnal species such as geckos (Diplodactylidae) differs to those experienced by diurnal species, and consequently future research should focus on disentangling predation risk experienced by lizard replicas for species exhibiting different activity phases.

Predation is likely to be an issue for lizard populations when predation pressure is high or populations are small. Frequent lizard predation, such as that seen on Mana Island and Matiu/Somes Island, is less likely to impact locally common lizard species than those that are rare and/or have restricted ranges. For example, high numbers of northern spotted skinks $(O$. kokowai) are frequently observed basking along walkways on Matiu/Somes Island despite high predation pressures exerted by birds (Pers. obs.). Increased risk exists for smaller populations, such as translocated or reintroduced species that have a limited number of founders, as the loss of individuals could drive them towards extinction (Atkinson 1990; Baling et al. 2013).

In some circumstances, such as with small populations recovering from mammal presence or translocated populations with a restricted founder size, it may be important to manage the risks posed by high impact avian predators. As the effect of avian predation on lizard populations has not been widely investigated within New Zealand, little work has looked at mitigating the risks posed by predatory birds to reptile species (e.g. Schneyer 2001). Methods that are used to control bird populations overseas may not be viable in New Zealand due to conservation 
conflict between native species, and legislation protecting wildlife. The presence of such conflict between native bird species and vulnerable lizard populations would be less likely to happen in undisturbed ecosystems. In New Zealand, the introduction of mammalian predators contributed to the loss of 58 of 228 bird species (Tennyson \& Martinson 2006). The loss of these species also results in the loss of structuring interactions they hold within the ecosystem, leading to ecological meltdown (Seastedt et al. 2008). Populations of birds that were once kept in check by larger predators, or competing species, can exert increased predation pressure on lizards whilst also recovering from the presence of mammals themselves.

Many recognised native lizard predators are protected under the New Zealand Wildlife Act (1953). Accordingly, issues can arise when looking to control native bird species due to full or partial protection offered by legislation. The two New Zealand native birds identified as prominent lizard predators by this study are only partially protected under the Wildlife Act (1953) and have previously been controlled within the Wellington region. Pūkeko are currently not controlled on Mana Island but have been shot in the past to limit impacts on revegetation efforts (Miskelly 1999). The eggs of southern black-backed gulls at Mana Island and Matiu/Somes Island are oiled to reduce the risk large populations pose to flying planes and threatened seabird species (Department of Conservation 2000; Miskelly 2010). Long-lasting control of birds has been achieved through culling local populations, but recolonisation by neighbouring meta-populations usually results in the reestablishment of populations (Bell \& Harborne 2018). It is feasible to control populations through local and targeted culling of both high impact species, if they offer risk to vulnerable lizard populations, but control would need to continue indefinitely while populations are recovering.

The eradication of bird populations on islands has been used in New Zealand successfully for flightless species. Weka (Gallirallus australis spp.) have been eradicated from at least nine offshore islands due to the conservation conflict they pose to native species (Miskelly \& Beauchamp 2004). Eradication is only an option when immigration by individuals is reduced and populations are contained (Millett et al. 2004; Bednarczuk et al. 2010; Phillips et al. 2012). If found to be problematic species, both non-natives and forest birds may be much harder to control than gulls or flightless birds. Control methods to target these species would have to take into account the disturbance of, and risk to, native fauna. Many introduced species are not protected under the Wildlife Act, including six recognised lizard predators: blackbirds, starlings, laughing kookaburra (Dacelo novaeguineae), Australian magpies (Gymnorhina 
tibicen), mynas (Acridotheres tristis), and Indian peafowl (Pavo cristatus). Population control of introduced birds occurs within New Zealand to reduce economic loss from crop damage, and usually relies on the use of the toxic bait alpha-chloralose (Nelson 1994). This avicide is non-specific and can result in the death of non-target species, and therefore its use may not be viable in places where native species are also present (Nelson 1994). The majority of forest birds have full protection under the Wildlife Act, and as such control of these species may not be possible if they are recognised as a risk to lizard populations. If they are not protected by legislation the environment they live in also limits control options, i.e. shooting, egg sterilisation, and toxin use is likely not viable. Additionally, for any bird control taking place we must also consider the cultural impact culling populations may have. Many native species are considered taonga to Māori and therefore local iwi must be consulted as kaitiaki before any control regimes are implemented (e.g. Bell \& Harborne 2018). Further research needs to be conducted to understand the risks posed by bird species, other than the high impact species recognised in this research, and to understand how predation risk may differ across the year due to the breeding ecology of predatory birds.

I used skink replicas to assess bird predation on New Zealand's lizard fauna at four sites within the Wellington region. The results from this study are taken from sites where restoration is currently being undertaken. Environments are dynamic places and it is important to understand that, as such, the risks lizards experience within these locations will also be dynamic. For example, the risks experienced by lizard populations may be high within open grassland areas, but as restoration proceeds regenerating forest may offer new risks in combination with less optimal habitat for the same species. It is likely that species turnover within environments due to translocations or changing habitat complexity will also alter predation risk by changing both predator and prey assemblages.

\subsection{Future research directions}

My research is limited to the threats faced by terrestrial skinks within the Wellington region. Future opportunities for research that would contribute to our understanding of avian predation on lizard populations across the country include: additional investigation into how to make a more effective and comparable lizard-mimicking replica; the further use of replica studies to identify other 'high' impact bird species; research contextualising predation risk experienced by lizard populations through the integration of lizard population and replica predation studies; 
research into how predation risk experienced by lizard replicas changes between breeding and non-breeding seasons for predatory bird species; further research to understand how predation risk imposed by birds differs between terrestrial and arboreal lizard species; and work to quantify lizard predation by pūkeko and southern black-backed gulls through both dietary analyses and observational studies. Knowledge gained through these studies will help restore lizard communities on the mainland, along the same successful path seen in birds. 
CHAPTER 4: SUMMARY AND IMPLICATIONS 


\section{References}

Atkinson IAE. 1990. Ecological restoration on islands: Prerequisites for success. Pages 73-90 in D. R. Towns, C. H. Daugherty, and I. A. E. Atkinson, editors. Ecological restoration of New Zealand islands. Conservation Sciences Publication No. 2. Department of Conservation, Wellington, NZ.

Baling M. 2017. Functional significance of highly variable colouration in the shore skink (Oligosoma smithi) [Unpublished PhD thesis]. Massey University, Auckland, NZ.

Baling M, Stuart-Fox D, Brunton DH, Dale J. 2016. Habitat suitability for conservation translocation: The importance of considering camouflage in cryptic species. Biological Conservation 206:298305.

Baling M, van Winkel D, Rixon M, Ruffell J, Ji W, Ussher G. 2013. A review of reptile research and conservation management on Tiritiri Matangi Island, New Zealand. New Zealand Journal of Ecology 37:272-281.

Ball O, Parrish R. 2005. Lizard predation by North Island fernbird (Bowdleria punctata vealeae). Notornis 52:250-251.

Bateman PW, Fleming PA, Rolek B. 2014. Bite me: Blue tails as a "risky-decoy" defense tactic for lizards. Current Zoology 60:333-337.

Bateman PW, Fleming PA, Wolfe AK. 2017. A different kind of ecological modelling: The use of clay model organisms to explore predator-prey interactions in vertebrates. Journal of Zoology 301:251-262.

Bates D, Mächler M, Bolker BM, Walker SC. 2015. Fitting linear mixed-effects models using lme4. Journal of Statistical Software 67:1-48.

Beckschäfer P. 2015. Hemispherical_2.0 - Batch processing hemispherical and canopy photographs with Image J - User Manual. Chair of Forest Inventory and Remote Sensing, Germany. Available from www.uni-goettingen.de/en/75936.html.

Bednarczuk E, Feare CJ, Lovibond S, Tatayah V, Jones CG. 2010. Attempted eradication of house sparrows Passer domesticus from Round Island (Mauritius), Indian Ocean. Conservation Evidence 7:75-86.

Bell BD. 1996. Blackbird (Turdus merula) predation on the endemic copper skink (Cyclodina aenea). Notornis 43:213-217. 
Bell EA, Bell BD, Merton D V. 2016. The legacy of Big South Cape: Rat irruption to rat eradication. New Zealand Journal of Ecology 40:212-218.

Bell M, Harborne P. 2018. Canterbury southern black-backed gull/karoro strategy. Unpublished Wildlife Management International Technical Report to Environment Canterbury. Blenheim, NZ.

Bell P, Nathan H, Mulgan N. 2019. 'Island' eradication within large landscapes: The remove and protect model. Occasional Paper SSC no. 62. Pages 604-610 in C. Veitch, M. Clout, A. Martin, J. Russell, and C. West, editors. Island invasives: Scaling up to meet the challenge. IUCN, Gland, Switzerland.

Bell T. 2019. Wellington City Council lizard surveys: 2016-2018. Technical report prepared for Wellington City Council by EcoGecko Consultants Limited, February 2019. Wellington, NZ.

Bellingham PJ, Towns DR, Cameron EK, Davis JJ, Wardle DA, Wilmshurst JM, Mulder CPH. 2010. New Zealand island restoration: Seabirds, predators, and the importance of history. New Zealand Journal of Ecology 34:115-136.

Birkhofer K, Bylund H, Dalin P, Ferlian O, Gagic V, Hambäck PA, Klapwijk M, Mestre L, Roubinet E, Schroeder M, Stenberg JA, Porcel M, Björkman C, Jonsson M. 2017. Methods to identify the prey of invertebrate predators in terrestrial field studies. Ecology and Evolution 7:1942-1953.

Brenton-Rule EC, Barbieri RF, Lester PJ. 2016. Corruption, development and governance indicators predict invasive species risk from trade. Proceedings of the Royal Society B: Biological Sciences 283:20160901.

Brodie III ED. 1993. Differential avoidance of coral snake banded patterns by free-ranging avian predators in Costa Rica. Evolution 47:227-235.

Brown JS. 1999. Vigilance, patch use and habitat selection: Foraging under predation risk. Evolutionary Ecology Research 1:49-71.

Buddle GA. 1951. Bird secrets. A.H. \& A.W. Reed, Wellington, NZ.

Buller WL. 1882. Manual of the birds of New Zealand. George Didsbury, Government Printer, Wellington, NZ.

Buller WL. 1888. Sceloglaux albifacies (Laughing Owl). Pages 198-205 A history of the birds of New Zealand (2nd ed.). Sir Walter Lowry Buller, London, UK.

Busbridge SA, Stewart JR. 2018. A video camera assessment of morepork (Ninox novaeseelandiae) diet and breeding success on Tiritiri Matangi Island. Notornis 65:187-195.

Cain PW, Cross MD. 2019. A low-cost method for simulating motion in studies using physical models of animals. Herpetological Review 50:718-721. 
Carrara F, Giometto A, Seymour M, Rinaldo A, Altermatt F. 2015. Inferring species interactions in ecological communities: A comparison of methods at different levels of complexity. Methods in Ecology and Evolution 6:895-906.

Carroll ALK. 1966. Food habits of pukeko (Porphyrio melanotus Temminck). Notornis 13:133-141.

Castilla AM, Gosá A, Galán P, Pérez-Mellado V. 1999. Green tails in lizards of the genus Podarcis:

Do they influence the intensity of predation? Herpetologica 55:530-537.

Castilla AM, Labra A. 1998. Predation and spatial distribution of the lizard Podarcis hispanica atrata: An experimental approach. Acta Oecologica 19:107-114.

Caughley G. 1994. Directions in conservation biology. The Journal of Animal Ecology 63:215-244.

Chalfoun AD, Martin TE. 2009. Habitat structure mediates predation risk for sedentary prey: Experimental tests of alternative hypotheses. Journal of Animal Ecology 78:497-503.

Chambers BS, Chambers S, Sibson RB. 1955. Notes on the Hen and Chickens Islands. Notornis 6:152-157.

Coleman JD, Warburton B, Green WQ. 1983. Some population statistics and movements of the western weka. Notornis 30:93-109.

Coombs G. 2016. Quantifying predation pressure and the protective role of sheltered basking sites for small snakes in South Africa. Phyllomedusa 15:155-162.

Cooper W. 2001. Black-fronted tern; Classified summarised notes, South Island and outlying islands, 1 July 1998 - 30 June 1999. Notornis 48:105.

Craig JL. 1974. The social organization of the pukeko Porphyrio porphyrio melanotus (Temminck, 1820) [Unpublished PhD thesis]. Massey University, NZ.

Cree A. 1994. Low annual reproductive output in female reptiles from New Zealand. New Zealand Journal of Zoology 21:351-372.

Cree A. 2014. Tuatara: Biology and conservation of a venerable survivor. Canterbury University Press, Christchurch, NZ.

Cree A, Hare KM. 2016. Reproduction and life history of New Zealand lizards. Pages 169-206 in D.

G. Chapple, editor. New Zealand Lizards. Springer International, Victoria, AU.

Crisp P. 2020. Conservation status of lizard species in the Wellington region. Greater Wellington Regional Council, Publication No. WRC/ESCI-G-20/2. Wellington, NZ.

Crooks KR, Soulé ME. 1999. Mesopredator release and avifaunal extinctions in a fragmented system. Nature 400:563-566. 
Crossland A, Freeman A. 1995. White-faced heron; Classified summarised notes: South Island 1 July 1992 - 30 June 1993. Notornis 42:59.

Cummings VJ, Schneider DC, Wilkinson MR. 1997. Multiscale experimental analysis of aggregative responses of mobile predators to infaunal prey. Journal of Experimental Marine Biology and Ecology 216:211-227.

Cuthill IC, Partridge JC, Bennett ATD, Church SC, Hart NS, Hunt S. 2000. Ultraviolet vision in birds. Advances in the Study of Behavior 29:159-214.

Daugherty CH, Gibbs GW, Hitchmough RA. 1993. Mega-island or micro-continent? New Zealand and its fauna. Trends in Ecology and Evolution 8:442.

Dawson DG, Bull PC. 1975. Counting birds in New Zealand forests. Notornis 22:101-109.

de Hamel FA, McInnes HM. 1971. Lizards as vectors of human salmonellosis. Journal of Hygiene 69:247-253.

Department of Conservation. 2000. Matiu/Somes Island - A plan for conservation management. Department of Conservation. Wellington, NZ.

Diego-Rasilla FJ. 2003a. Influence of predation pressure on the escape behaviour of Podarcis muralis lizards. Behavioural Processes 63:1-7.

Diego-Rasilla FJ. 2003b. Human influence on the tameness of wall lizard, Podarcis muralis. Italian Journal of Zoology 70:225-228.

Draulans D. 1987. The effect of prey density on foraging behaviour and success of adult and first-year grey herons (Ardea cinerea). The Journal of Animal Ecology 56:479.

Dumont CT. 2015. An investigation into declining skink populations and their behavioural responses to introduced mammalian predators [Unpublished MSc thesis]. University of Canterbury, Christchurch, NZ.

Eagle A. 2001. NZ pipit; Classified summarised notes, South Island and outlying islands, 1 July 1997 - 30 June 1998. Notornis 48:98.

Edgar AT, Grant P. 1969. Nankeen kestrels in New Zealand. Notornis 16:288-298.

Edwards JS. 1952. Kingfisher; Summarised classified notes. Notornis 4:191.

Endler JA. 1990. On the measurement and classification of colour in studies of animal colour patterns. Biological Journal of the Linnean Society 41:315-352.

Estes JA, Palmisano JF. 1974. Sea otters: Their role in structuring nearshore communities. Science 185:1058-1060. 
Falla RA, Sibson RB, Turbott EG. 1978. Collins guide to the birds of New Zealand and outlying islands (Ed. rev.). Collins, Auckland, NZ.

Fitzgerald BM, Meads MJ, Whitaker AH. 1986. Food of the kingfisher (Halcyon sancta) during nesting. Notornis 31:23-32.

Flux J, Flux M. 1981. Population dynamics and age structure of starlings (Sturnus vulgaris) in New Zealand. New Zealand Journal of Ecology 4:65-72.

Fordham RA, Cormack RM. 1970. Mortality and population change of dominican gulls in Wellington, New Zealand: With a statistical appendix. The Journal of Animal Ecology 39:13-27.

Fox N. 1977. The biology of the New Zealand Falcon (Falco novaeseelandlae Gmelin 1788) [Unpublished MSc thesis]. University of Canterbury, Christchurch, NZ.

Galbraith M, Krzyżosiak J, Aguilar G, Jones G, Oliver R. 2015. Changes in the breeding status of the southern black-backed gull (Larus dominicanus) colonies on Rangitoto Island, Hauraki Gulf, New Zealand. Notornis 62:192-201.

Gardner-Gee R, Graham S, Griffiths R, Habgood M, Dunlop SH, Lindsay H. 2007. Motuora native species restoration plan. Department of Conservation and Motuora Restoration Society. Auckland, NZ.

Gibb JA. 2000. Activity of birds in the Western Hutt Hills, New Zealand. Notornis 47:13-35.

Gibbs G. 2010. Do New Zealand invertebrates reflect the dominance of birds in their evolutionary history? New Zealand Journal of Ecology 34:152-157.

Gill BJ, Zhu A, Patel S. 2018. Post-mortem examinations of New Zealand birds. 2. Long-tailed cuckoos (Eudynamys taitensis, Aves: Cuculinae). New Zealand Journal of Zoology 45:371-386.

Greenberg R, Mettke-Hofmann C. 2001. Ecological aspects of neophobia and neophilia in birds. Pages 119-178 Current Ornithology. Springer, Boston, MA, USA.

Habgood MJ. 2003. Behavioural interactions between copper (Cyclodina aenea) and moko (Oligosoma moco) skinks: Implications for translocations [Unpublished MSc thesis]. University of Auckland, Auckland, NZ.

Hansen NA, Sato CF, Michael DR, Lindenmayer DB, Driscoll DA. 2019. Predation risk for reptiles is highest at remnant edges in agricultural landscapes. Journal of Applied Ecology 56:31-43.

Hare KM, Chapple DG, Towns DR, van Winkel D. 2016. The ecology of New Zealand's lizards. Pages 133-168 in D. G. Chapple, editor. New Zealand Lizards. Springer International, Victoria, AU. 
Hare KM, Miller KA. 2010. Frequency of tail loss does not reflect innate predisposition in temperate New Zealand lizards. Naturwissenschaften 97:197-203.

Hartley LJ. 2012. Five-minute bird counts in New Zealand. New Zealand Journal of Ecology 36:268278.

Heather BD, Robertson HA. 1996. The fieldguide to the birds of New Zealand (1st ed.).

Viking/Penguin Books Ltd, Auckland, NZ.

Hector J. 2011. A new cloak for Matiu: The restoration of an island ecology. The Lower Hutt Branch of the Royal Forest and Bird Protection Society of New Zealand, Lower Hutt, NZ.

Hitchmough R, Adams L, Reardon J, Monks J. 2016a. Current challenges and future directions in lizard conservation in New Zealand. Journal of the Royal Society of New Zealand 46:29-39.

Hitchmough R, Barr B, Lettink M, Monks J, Reardon J, Tocher M, van Winkel D, Rolfe J. 2015. Conservation status of New Zealand reptiles, 2015. New Zealand Threat Classification Series 17. Department of Conservation, Wellington, NZ.

Hitchmough RA, Patterson GB, Chapple DG. 2016b. Putting a name to diversity: Taxonomy of the New Zealand lizard fauna. Pages 87-108 in D. G. Chapple, editor. New Zealand Lizards. Springer International, Victoria, AU.

Hoare JM, Pledger S, Nelson NJ, Daugherty CH. 2007. Avoiding aliens: Behavioural plasticity in habitat use enables large, nocturnal geckos to survive Pacific rat invasions. Biological Conservation 136:510-519.

Hooper DU, Chapin III FS, Ewel JJ, Hector A, Inchausti P, Lavorel S, Lawton JH, Lodge DM, Loreau M, Naeem S, Schmidt B, Setala H, Symstad AJ, Vandermeer J, Wardle DA. 2005. Effects of biodiversity on ecosystem functioning: A consensus of current knowledge. Ecological Monographs 75:3-35.

Horikoshi C, Battley PF, Seaton R, Minot EO. 2017. Winter habitat use of New Zealand falcons (Falco novaeseelandiae ferox) in an intensively managed pine plantation, central north Island, New Zealand. New Zealand Journal of Ecology 41:193-206.

Huey RB, Pianka ER. 1981. Ecological consequences of foraging mode. Ecology 62:991-999.

Huffaker C. 1958. Experimental studies on predation: Dispersion factors and predator-prey oscillations. Hilgardia 27:343-383.

Hulme PE. 2009. Trade, transport and trouble: Managing invasive species pathways in an era of globalization. Journal of Applied Ecology 46:10-18. 
Husak JF, Macedonia JM, Fox SF, Sauceda RC. 2006. Predation cost of conspicuous male coloration in collared lizards (Crotaphytus collaris): An experimental test using clay-covered model lizards. Ethology 112:572-580.

Innes J, Kelly D, Overton JMC, Gillies C. 2010. Predation and other factors currently limiting New Zealand forest birds. New Zealand Journal of Ecology 34:86-114.

Kennedy RJ. 1970. Direct effects of rain on birds: A review. British Birds 63:401-414.

Knox C. 2014. Tail loss as an indicator for predation pressure on Naultinus populations. BioGecko 2:22-26.

Kross SM, Tylianakis JM, Nelson XJ. 2013. Diet composition and prey choice of New Zealand falcons nesting in anthropogenic and natural habitats. New Zealand Journal of Ecology 37:51-59.

Lalas C. 1977. Food and feeding behaviour of the black-fronted tern, Chlidonias hybrida albostriatus [Unpublished MSc thesis]. University of Otago, Dunedin, NZ.

Langkilde T, Shine R, Mason RT. 2004. Predatory attacks to the head vs. body modify behavioral responses of garter snakes. Ethology 110:937-947.

Langley CM. 1996. Search images: Selective attention to specific visual features of prey. Journal of Experimental Psychology: Animal Behavior Processes 22:152-163.

Lemessa D, Hambäck PA, Hylander K. 2015. Arthropod but not bird predation in Ethiopian homegardens is higher in tree-poor than in tree-rich landscapes. PLoS ONE 10:e0126639.

Lima SL. 1998. Nonlethal effects in the ecology of predator-prey interactions. BioScience 48:25-34.

Linklater W, Steer J. 2018. Predator Free 2050: A flawed conservation policy displaces higher priorities and better, evidence-based alternatives. Conservation Letters:e12593.

Lovegrove TG. 1981. Blackbird; Classified summarised notes. Notornis 28:80.

Low PA, Sam K, McArthur C, Posa MRC, Hochuli DF. 2014. Determining predator identity from attack marks left in model caterpillars: Guidelines for best practice. Entomologia Experimentalis et Applicata 152:120-126.

Lynch J. 2019. Zealandia: The valley that changed a nation. Kotare Publications, Waikanae, NZ.

Mander R. 1972. Reef heron; Classified summarised notes 1963-1970. Notornis 19:27.

Marples BJ. 1942. A study of the little owl, Athene noctua, in New Zealand. Transactions and Proceedings of the Royal Society of New Zealand 72:237-252.

Marshall KLA, Philpot KE, Stevens M. 2015. Conspicuous male coloration impairs survival against avian predators in Aegean wall lizards, Podarcis erhardii. Ecology and Evolution 5:4115-4131. 
Martin J, Lopez P. 1996. Avian predation on a large lizard (Lacerta lepida) found at low population densities in Mediterranean habitats: An analysis of bird diets. Copeia 3:722-726.

Mason LD, Wardell-Johnson G, Luxton SJ, Bateman PW. 2018. Predators show seasonal predilections for model clay spiders in an urban environment. Scientific Reports 8:12444.

McArthur N, Harvey A, Flux I. 2015. State and trends in the diversity, abundance and distribution of birds in Wellington City. Client report prepared for Greater Wellington Regional Council. Wildlife International Limited, Blenheim, NZ.

McCaskill LW. 1945. Preliminary report on the present position of the Australian magpies Gymnorhina hypoleuca and G. tibicen in New Zealand. New Zealand Bird Notes 1:86-104.

McIlroy JC. 1968. The biology of magpies (Gymnorhina spp.) in New Zealand [Unpublished MAgSc thesis]. University of Canterbury, Christchurch, NZ.

McKenzie HR. 1955. Kingfisher; Classified summarised notes. Notornis 6:104.

McKenzie KL. 2007. Returning tuatara (Sphenodon punctatus) to the New Zealand mainland [Unpublished MSc thesis]. Victoria University of Wellington, Wellington, NZ.

McLennan JA, Potter, MA, Robertson HA, Wake GC, Colbourne R, Dew L, Joyce L, McCann AJ, Miles J, Miller PJ, Reid J. 1996. Role of predation in the decline of Kiwi, Apteryx spp., in New Zealand. New Zealand Journal of Ecology 20:27-35.

McMillan DM, Irschick DJ. 2010. Experimental test of predation and competition pressures on the green anole (Anolis carolinensis) in varying structural habitats. Journal of Herpetology 44:272278.

Mead WP. 1947. Kingfisher; Classified summarised notes. New Zealand Bird Notes 2:50.

Meckstroth AM, Miles AK, Chandra S. 2007. Diets of introduced predators using stable isotopes and stomach contents. Journal of Wildlife Management 71:2387-2392.

Melzer S, Bell T. 2014. Lizard survey of Wellington City Council administered parks \& reserves: Final report. Unpublished EcoGecko Consultants Ltd report prepared for the Wellington Council, June 2014. EcoGecko Consultants Ltd, Wellington, NZ.

Menge BA. 1995. Indirect effects in marine rocky intertidal interaction webs: Patterns and importance. Ecological Monographs 65:21-74.

Millett J, Climo G, Shah NJ. 2004. Eradication of common mynah Acridotheres tristis populations in the granitic Seychelles: Successes, failures and lessons learned. Advances in Vertebrate Pest Management 3:169-183. 
Miskelly C. 1999. Mana Island ecological restoration plan. Department of Conservation, Wellington, NZ.

Miskelly C. 2010. Mana Island ecological restoration plan review. Department of Conservation, Wellington, NZ.

Miskelly C, Beauchamp T. 2004. Weka, a conservation dilemma. Pages 81-87 in K. Brown, editor. Restoring Kapiti: Nature's second chance. University of Otago Press, Dunedin, NZ.

Miskelly CM. 1997. Whitaker's skink Cyclodina whitakeri eaten by a weasel Mustela nivalis. Conservation Advisory Science Notes No. 146. Department of Conservation, Wellington, NZ.

Miskelly CM. 2018. Changes in the forest bird community of an urban sanctuary in response to pest mammal eradications and endemic bird reintroductions. Notornis 65:132-151.

Moeed A. 1976. Birds and their food resources at Christchurch International Airport, New Zealand. New Zealand Journal of Zoology 3:373-390.

Monks JM, Monks A, Towns DR. 2014. Correlated recovery of five lizard populations following eradication of invasive mammals. Biological Invasions 16:167-175.

Moon G. 1986. Short note: The feeding of New Zealand kingfisher chicks. Notornis 38:232.

Morrison J V., Morrison K. 2002. NZ kingfisher; Classified summarised notes, South Island and outlying islands, 1 July 1999 to 30 June 2000. Notornis 49:114.

Muchula K, Xie G, Gurr GM. 2019. Ambient temperature affects the utility of plasticine caterpillar models as a tool to measure activity of predators across latitudinal and elevational gradients. Biological Control 129:12-17.

Myers N, Mittermeler RA, Mittermeler CG, Da Fonseca GAB, Kent J. 2000. Biodiversity hotspots for conservation priorities. Nature 403:853-858.

Nelson NJ, Romijn RL, Dumont T, Reardon JT, Monks JM, Hitchmough RA, Empson R, Briskie J V. 2016. Lizard conservation in mainland sanctuaries. Pages 321-339 in D. G. Chapple, editor. New Zealand Lizards. Springer International, Victoria, AU.

Nelson PC. 1994. Bird control in New Zealand using alpha-chloralose and DRC1339. Pages 259-264 Proceedings of the Sixteenth Vertebrate Pest Conference (1994). Available from https://digitalcommons.unl.edu/vpc16/40.

Newman DG. 1994. Effects of a mouse, Mus musculus, eradication programme and habitat change on lizard populations of Mana Island, New Zealand, with special reference to McGregor's skink, Cyclodina macgregori. New Zealand Journal of Zoology 21:443-456. 
Nielsen S V., Bauer AM, Jackman TR, Hitchmough RA, Daugherty CH. 2011. New Zealand geckos (Diplodactylidae): Cryptic diversity in a post-Gondwanan lineage with trans-Tasman affinities. Molecular Phylogenetics and Evolution 59:1-22.

Nilsson RJ, Kennedy ES, West JA. 1994. The birdlife of South East Island (Rangatira), Chatham Islands, New Zealand. Notornis 41:109-125.

O'Donnell CF. 1981. Foods of the New Zealand kingfisher (Halcyon sancta vagans). Notornis 28:140-141.

O’Donnell CF, Dilks PJ. 1994. Foods and foraging of forest birds in temperate rainforest, South Westland, New Zealand. New Zealand Journal of Ecology 18:87-107.

O'Donnell CFJ. 1996. Predators and the decline of New Zealand forest birds: An introduction to the hole-nesting bird and predator programme. New Zealand Journal of Zoology 23:213-219.

O’Donnell CFJ, Hoare JM. 2009. Predation of lizards by black-fronted terns (Sterna albostriata). Notornis 56:167-168.

Oliver WRB. 1955. New Zealand birds, 2nd edition. A.H. \& A.W. Reed, Wellington, NZ.

Owens B. 2017. The big cull: Can New Zealand pull off an audacious plan to get rid of invasive predators by 2050? Nature 541:148-150.

Padilla DP, Nogales M, Marrero P. 2007. Prey size selection of insular lizards by two sympatric predatory bird species. Acta Ornithologica 42:167-172.

Paine RT. 1966. Food web complexity and species diversity. The American Naturalist 100:65-75.

Paluh DJ, Kenison EK, Saporito RA. 2015. Frog or fruit? The importance of color and shape to bird predators in clay model experiments. Copeia 103:58-63.

Parkes JP, Byrom AE, Edge KA. 2017a. Eradicating mammals on New Zealand island reserves: What is left to do? New Zealand Journal of Ecology 41:263-270.

Parkes JP, Nugent G, Forsyth DM, Byrom AE, Pech RP, Warburton B, Choquenot D. 2017b. Past, present and two potential futures for managing New Zealand's mammalian pests. New Zealand Journal of Ecology 41:151-161.

Parrish GR. 1997. Morepork; Classified summarised notes, North Island 1 July 1995 to 30 June 1996. Notornis 44:105.

Parrish GR, Gill BJ. 2003. Natural history of the lizards of the Three Kings Islands, New Zealand. New Zealand Journal of Zoology 30:205-220. 
Parrish GR, Pierce RJ. 1997. Morepork; Classified summarised notes, North Island 1 July 1995 to 30 June 1996. Notornis 44:105.

Pérez-Mellado V, Garrido M, Ortega Z, Pérez-Cembranos A, Mencía A. 2014. The yellow-legged gull as a predator of lizards in Balearic Islands. Amphibia-Reptilia 35:207-213.

Phillips RB, Cooke BD, Carrión V, Snell HL. 2012. Eradication of rock pigeons, Columba livia, from the Galápagos Islands. Biological Conservation 147:264-269.

Pierce RJ. 1980. Seasonal and long-term changes in bird numbers at Lake Wainono. Notornis 27:2144.

Pierce RJ, Maloney RF. 1989. Responses of harriers in the Mackenzie Basin to the abundance of rabbits. Notornis 36:1-12.

Piorno V, Fernández J-A, Velo-Antón G. 2016. The yellow-legged gull, Larus michahellis, an occasional predator of Timon lepidus in the Atlantic Islands National Park (Galicia, NW Spain). Boletín de la Asociación Herpetológica Española 27:31-36.

Polis GA, Strong DR. 1996. Food web complexity and community dynamics. The American Naturalist 147:813-846.

Powell MJD. 2009. The BOBYQA algorithm for bound constrained optimization without derivatives. Cambridge NA Report NA2009/06. Cambridge, England, UK.

Powlesland RG, Robertson HA. 1987. Changes in gull numbers over 25 years and notes on other birds of the Otaki-Ohau coast. Notornis 34:327-338.

Predator Free Wellington. 2019. 2018/19 Impact: How do we create the world's first predator free capital city? Available from https://www.pfw.org.nz/2018-19-impact-report/.

Pryde MA, O’Donnell CFJ, Barker RJ. 2005. Factors influencing survival and long-term population viability of New Zealand long-tailed bats (Chalinolobus tuberculatus): Implications for conservation. Biological Conservation 126:175-185.

Purger JJ, Lanszki Z, Szép D, Bocz R. 2017. Predation of common wall lizards: Experiences from a study using scentless plasticine lizards. Acta Herpetologica 12:181-186.

Ramsay GW, Watt JC. 1971. Notes on the birds of Great Island, Three Kings Islands. Notornis 18:287-290.

Ramsey DSL, Norbury GL. 2009. Predicting the unexpected: Using a qualitative model of a New Zealand dryland ecosystem to anticipate pest management outcomes. Austral Ecology 34:409421. 
Rangen SA, Clark RG, Hobson KA. 2000. Visual and olfactory attributes of artificial nests. The Auk 117:136-146.

Reardon JT, Whitmore N, Holmes KM, Judd LM, Hutcheon AD, Norbury G, Mackenzie DI. 2012. Predator control allows critically endangered lizards to recover on mainland New Zealand. New Zealand Journal of Ecology 36:141-150.

Redhead RE. 1969. Some aspects of the feeding of the harrier. Notornis 16:262-284.

Reid S. 2009. Tiritiri Matangi: An educational resource for schools (2nd ed.). Department of Conservation, Auckland, NZ.

Ritchie EG, Johnson CN. 2009. Predator interactions, mesopredator release and biodiversity conservation. Ecology Letters 12:982-998.

Roberts R V. 1952. Kingfisher; Summarised classified notes. Notornis 4:191.

Robertson HA, Baird K, Dowding JE, Elliott GP, Hitchmough RA, Miskelly CM, McArthur N, O’Donnell CFJ, Sagar PM, Scofield RP, Taylor GA. 2017. Conservation status of New Zealand birds, 2016. New Zealand Threat Classification Series 19. Department of Conservation, Wellington, NZ.

Rodda GH, Savidge JA. 2007. Biology and impacts of Pacific Island invasive species. 2. Boiga irregularis, the brown tree snake (Reptilia: Colubridae) 1. Pacific Science 61:307-324.

Romijn RL. 2013. Can skinks recover in the presence of mice? [Unpublished BSc(Hons) thesis]. Victoria University of Wellington, Wellington, NZ.

Romijn RL, Hartley S. 2016. Trends in lizard translocations in New Zealand between 1988 and 2013. New Zealand Journal of Zoology 43:191-210.

Rößler DC, Pröhl H, Lötters S. 2018. The future of clay model studies. BMC Zoology 3:6.

Ruscoe WA, Ramsey DSL, Pech RP, Sweetapple PJ, Yockney I, Barron MC, Perry M, Nugent G, Carran R, Warne R, Brausch C, Duncan RP. 2011. Unexpected consequences of control: Competitive vs. predator release in a four-species assemblage of invasive mammals. Ecology Letters 14:1035-1042.

Russell JC. 2014. A comparison of attitudes towards introduced wildlife in New Zealand in 1994 and 2012. Journal of the Royal Society of New Zealand 44:136-151.

Russell JC, Broome KG. 2016. Fifty years of rodent eradications in New Zealand: Another decade of advances. New Zealand Journal of Ecology 40:197-204. 
Russell JC, Innes JG, Brown PH, Byrom AE. 2015. Predator-free New Zealand: Conservation country. BioScience 65:520-525.

Salo P, Korpimäki E, Banks PB, Nordström M, Dickman CR. 2007. Alien predators are more dangerous than native predators to prey populations. Proceedings of the Royal Society B: Biological Sciences 274:1237-1243.

Sato CF, Wood JT, Schroder M, Green K, Osborne WS, Michael DR, Lindenmayer DB. 2014. An experiment to test key hypotheses of the drivers of reptile distribution in subalpine ski resorts. Journal of Applied Ecology 51:13-22.

Saunders SP, Cuthbert FJ, Zipkin EF. 2018. Evaluating population viability and efficacy of conservation management using integrated population models. Journal of Applied Ecology 55:1380-1392.

Savoca MS, Gardiner J, Colbourne R, Tennyson AJD. 2018. Vertebrate prey in the diets of freeranging kiwi (Apteryx spp.). Notornis 65:242-244.

Scarlett R. 1972. New Zealand kingfisher; Classified summarised notes 1963-1970. Notornis 19:71.

Schneider CA, Rasband WS, Eliceiri KW. 2012. NIH Image to ImageJ: 25 years of image analysis. Nature methods 9:671.

Schneyer N. 2001. Effects of avian predation and habitat degradation on the population dynamics of the jewelled gecko (Naultinus gemmeus) from the Every Scientific Reserve, Otago Peninsula, New Zealand [Unpublished MSc thesis]. Otago University, Dunedin, NZ.

Seastedt TR, Hobbs RJ, Suding KN. 2008. Management of novel ecosystems: Are novel approaches required? Frontiers in Ecology and the Environment 6:547-553.

Serong M, Lill A. 2016. Plasticity and stereotypy in avian foraging during secondary succession in temperate forests. Avian Biology Research 9:174-194.

Seymoure BM, Raymundo A, Mcgraw KJ, Owen Mcmillan W, Rutowski RL. 2018. Environmentdependent attack rates of cryptic and aposematic butterflies. Current Zoology 64:663-669.

Shanahan D, Michel P, Ledington J, Irwin E, Dobson-Waitere A. 2019. The ZEALANDIA/Te Māra a Tāne conservation and restoration strategy 2018-2038. Zealandia Ecosanctuary, Wellington, New Zealand.

Shepard DB. 2007. Habitat but not body shape affects predator attack frequency on lizard models in the Brazilian Cerrado. Herpetologica 63:193-202.

Sherley GH. 1998. Threatened weta recovery plan. Threatened species recovery plan No. 25 .

Department of Conservation. Wellington, NZ. 
Sherley GH, Stringer IAN, Parrish GR. 2010. Summary of native bat, reptile, amphibian and terrestrial invertebrate translocations in New Zealand. Science for Conservation No. 303. Department of Conservation. Wellington, NZ.

Sibson RB. 1949. Visit to Little Barrier. New Zealand Bird Notes 3:151-155.

Sih A, Bolnick DI, Luttbeg B, Orrock JL, Peacor SD, Pintor LM, Preisser E, Rehage JS, Vonesh JR. 2010. Predator-prey naïveté, antipredator behavior, and the ecology of predator invasions. Oikos 119:610-621.

Simberloff D, Martin JL, Genovesi P, Maris V, Wardle DA, Aronson J, Courchamp F, Galil B, García-Berthou E, Pascal M, Pyšek P, Sousa R, Tabacchi E, Vilà M. 2013. Impacts of biological invasions: What's what and the way forward. Trends in Ecology and Evolution 28:58-66.

Smith SM. 1973. A study of prey-attack behaviour in young loggerhead shrikes, Lanius ludovicianus L. Behaviour 44:113-141.

Soule ME. 1985. What is conservation biology? A new synthetic discipline addresses the dynamics and problems of perturbed species, communities, and ecosystems. BioScience 35:727-734.

St. Paul R, McKenzie HR. 1977. A bushman's seventeen years of noting birds: Part E - New Zealand pigeon, North Island kaka, yellow-crowned parakeet and kingfisher. Notornis 24:20-30.

Steffen JE. 2009. Perch-height specific predation on tropical lizard clay models: Implications for habitat selection in mainland neotropical lizards. Revista de Biologia Tropical 57:859-864.

Tennyson AJD, Martinson P. 2006. Extinct birds of New Zealand. Te Papa Press, Wellington, NZ.

Terborgh J, Lopez L, Nuñez PV, Rao M, Shahabuddin G, Orihuela G, Riveros M, Ascanio R, Adler GH, Lambert TD, Balbas L. 2001. Ecological meltdown in predator-free forest fragments. Science 294:1923-1926.

Thompson MB. 2000. Oligosoma spp. (New Zealand skinks) predation. Herpetological Review 31:175.

Towns DR. 1996. Changes in habitat use by lizards on a New Zealand island following removal of the introduced Pacific rat Rattus exulans. Pacific Conservation Biology 2:286-292.

Towns DR. 1999. Cyclodina spp. skink recovery plan, 1999-2004. Department of Conservation, Wellington, NZ.

Towns DR, Daugherty CH. 1994. Patterns of range contractions and extinctions in the New Zealand herpetofauna following human colonisation. New Zealand Journal of Zoology 21:325-339. 
Towns DR, Ferreira SM. 2001. Conservation of New Zealand lizards (Lacertilia: Scincidae) by translocation of small populations. Biological Conservation 98:211-222.

Towns DR, West CJ, Broome KG. 2013. Purposes, outcomes and challenges of eradicating invasive mammals from New Zealand islands: An historical perspective. Wildlife Research 40:94-107.

Trewick S. 1996. The diet of kakapo (Strigops habroptilus), takahe (Porphyrio mantelli) and pukeko (P. porphyrio melanotus) studied by faecal analysis. Notornis 43:79-84.

Turbott EG, Buddle GA. 1948. Birds of the Three Kings Islands. Records of the Auckland Institute and Museum 3:319-336.

van Winkel D. 2008. Efficiency of techniques for post-translocation monitoring of the Duvaucel's gecko (Hoplodactylus duvaucelii) and evidence of native avian predation on lizards [Unpublished MSc thesis]. Massey University, Auckland, NZ.

van Winkel D, Baling M, Hitchmough R. 2018. Reptiles and amphibians of New Zealand: A field guide. Auckland University Press, Auckland, NZ.

van Winkel D, Ji W. 2012. Evidence of lizard predation by New Zealand kingfishers (Todiramphus sanctus vagans) and potential implications for threatened species translocations. New Zealand Journal of Zoology 39:201-208.

Vervust B, Van Loy H, Van Damme R. 2011. Seeing through the lizard's trick: Do avian predators avoid autotomous tails? Central European Journal of Biology 6:293-299.

Veselý P, Luhanová D, Prášková M, Fuchs R. 2013. Generalization of mimics imperfect in colour patterns: The point of view of wild avian predators. Ethology 119:138-145.

Vitousek PM, DAntonio CM, Loope LL, Westbrooks R, D’Antonio CM. 1996. Biological invasions as global environmental change. American Naturalist 84:468-478.

von Hugel A. 1875. Letter to RB Sharpe. Ibis 17:389-394.

Watts C, Thornburrow D, Cave V, Innes J. 2014. Beetle community changes following pest mammal control at two biodiversity sanctuaries in Wellington, New Zealand. Journal of the Royal Society of New Zealand 44:61-87.

Watts C, Thornburrow D, Stringer I, Cave V. 2017. Population expansion by Cook Strait giant wētā, Deinacrida rugosa (Orthoptera: Anostostomatidae), following translocation to Matiu/Somes Island, New Zealand, and subsequent changes in abundance. Journal of Orthoptera Research 26:171-180. 
Watts CH, Armstrong DP, Innes J, Thornburrow D. 2011. Dramatic increases in weta (Orthoptera) following mammal eradication on Maungatautari - evidence from pitfalls and tracking tunnels. New Zealand Journal of Ecology 35:261-272.

Webb JK, Whiting MJ. 2005. Why don’t small snakes bask? Juvenile broad-headed snakes trade thermal benefits for safety. Oikos 110:515-522.

Weeks MF. 1949. Bird population of exotic forests, 1940-1948. New Zealand Bird Notes 3:83.

Wellington City Council. 2015. Our natural capital: Wellington's biodiversity strategy and action plan 2015. Wellington City Council, Wellington, NZ.

Whitaker AH. 1973. Lizard populations on islands with and without Polynesian rats, Rattus exulans (Peale). Proceedings of the New Zealand Ecological Society 20:121-130.

Whitaker AH. 1986. The lizards of the Poor Knights Islands, New Zealand. New Zealand Journal of Science 11:623-651.

Whitaker AH. 1987. The roles of lizards in New Zealand plant reproductive strategies. New Zealand Journal of Botany 25:315-328.

Whitaker AH. 1991. Research on the striped gecko (Hoplodactylus stephensi), on Maud Island, Pelorus Sound, Marlborough: 6 - 12 March 1991. Unpublished report. New Zealand Department of Conservation, Nelson, NZ.

Wickham H. 2016. ggplot2: Elegant Graphics for Data Analysis. Springer-Verlag, New York, NY, USA.

Wildlife Act. 1953. New Zealand legislation. New Zealand Government. Available from http://www.legislation.govt.nz/act/public/1953/0031/72.0/DLM276814.html.

Wiles GJ, Bart J, Beck RE, Aguon CF. 2003. Impacts of the brown tree snake: Patterns of decline and species persistence in Guam's avifauna. Conservation Biology 17:1350-1360.

Wilkinson AS, Wilkinson A. 1952. Kapiti bird sanctuary: A natural history of the island. (Stidolph RHD, editor). Masterton Printing Company Ltd., Masterton, NZ.

Wilmshurst JM, Anderson AJ, Higham TFG, Worthy TH. 2008. Dating the late prehistoric dispersal of Polynesians to New Zealand using the commensal Pacific rat. Proceedings of the National Academy of Sciences of the United States of America 105:7676-7680.

Wishart ML. 2008. Pukeko (Porphyrio porphyrio) predation of a house sparrow (Passer domesticus). Notornis 55:158-159. 
Wittmer HU, Sinclair ARE, McLellan BN. 2005. The role of predation in the decline and extirpation of woodland caribou. Oecologia 144:257-267.

Worthy TH. 2001. A fossil vertebrate fauna accumulated by laughing owls (Sceloglaux albifacies) on the Gouland Downs, Northwest Nelson, South Island. Notornis 48:225-233.

Wotton DM, Drake DR, Powlesland RG, Ladley JJ. 2016. The role of lizards as seed dispersers in New Zealand. Journal of the Royal Society of New Zealand 46:40-65.

Zavaleta ES, Hobbs RJ, Mooney HA. 2001. Viewing invasive species removal in a whole-ecosystem context. Trends in Ecology and Evolution 16:454-459. 